Journal for Educational Research Online

Journal für Bildungsforschung Online

https://doi.org/10.31244/jero.2021.01.02

Volume 13 (2021), No. 1, 16-77

CC BY-NC-SA 4.0 Waxmann 2021

Christoph Homuth, Elisabeth Liebau \& Gisela Will

\title{
The role of socioeconomic, cultural, and structural factors in daycare attendance among refugee children
}

\begin{abstract}
Previous research has found that ethnic educational inequalities arise even before children enroll in primary school. It has been shown that especially for migrants, early participation in education has a positive impact on later educational outcomes, with the acquisition of the host-country language being one of the main mechanisms driving this effect. With the influx of over one million refugees into Germany in recent years, the integration of migrant children, especially refugee children, into the educational system is more salient in educational politics than ever. The first empirical findings on early and preschool education among refugees have shown that while a considerable share of refugee children attend a daycare center, they do so at lower rates than native and other migrant children. This paper aims to examine whether inequalities in the early education of refugee children can be explained by different socioeconomic and migration-related factors known to be associated with inequality in daycare attendance and to explore whether additional refugee-specific factors affect the likelihood of enrollment in preschool education. With data from the IAB-BAMF-SOEP Survey of Refugees in Germany and the study Refugees in the German Educational System (ReGES), we show that conventional explanatory variables do affect refugee children's attendance of daycare centers. In addition to children's age, the employment status of the mother, and the length of stay in Germany are particularly important. However, we see regional differences in participation in preschool education that cannot be explained by the municipal childcare supply.
\end{abstract}

\section{Keywords}

Refugees; Early education; Preschool education; Daycare; Social inequality

Dr. Christoph Homuth (corresponding author) - Dr. Gisela Will, Leibniz Institute for Educational Trajectories (LIfBi), Wilhelmsplatz 3, 96047 Bamberg, Germany

e-mail: christoph.homuth@lifbi.de gisela.will@lifbi.de

Dr. Elisabeth Liebau, German Institute for Economic Research (DIW Berlin), Mohrenstraße 58, 10117 Berlin, Germany

e-mail: eliebau@diw.de 


\section{Der Einfluss sozioökonomischer, kultureller und struktureller Faktoren auf den Kindertagesstätten- besuch von geflüchteten Kindern}

\section{Zusammenfassung}

Bisherige Studien haben gezeigt, dass ethnische Bildungsungleichheiten bereits vor der Einschulung entstehen. Es wurde gezeigt, dass insbesondere für Lernende mit Migrationshintergrund eine frühe Bildungsbeteiligung einen positiven Einfluss auf die späteren Bildungsergebnisse hat, wobei der Erwerb der Sprache des Aufnahmelandes einer der Hauptmechanismen für diesen Effekt ist. Mit der Zuwanderung von über einer Million Schutzsuchenden nach Deutschland in den letzten Jahren ist die Integration von Migrantenkindern, insbesondere von geflüchteten Kindern, in das Bildungssystem bildungspolitisch aktueller denn je. Erste empirische Befunde zur frühkindlichen und vorschulischen Bildung von Geflüchteten haben gezeigt, dass zwar ein erheblicher Anteil der geflüchteten Kinder eine Kindertagesstätte besucht, ihre Betreuungsquoten sind jedoch geringer als die von einheimischen und anderen Migrantenkindern. In diesem Beitrag soll untersucht werden, ob Ungleichheiten in der frühen Bildung von geflüchteten Kindern durch verschiedene sozioökonomische und migrationsspezifische Faktoren erklärt werden können, von denen aus der Literatur bekannt ist, dass sie mit Ungleichheiten im Kindertagesstättenbesuch einhergehen, und ob zusätzliche flüchtlingsspezifische Faktoren die Wahrscheinlichkeit den Besuch einer Kindertagesstätte beeinflussen. Mit Daten aus der IAB-BAMFSOEP-Befragung von Geflüchteten in Deutschland und der Studie Refugees in the German Educational System (ReGES) zeigen wir, dass bekannte Determinanten den Kindertagesstättenbesuch von geflüchteten Kindern tatsächlich beeinflussen. Neben dem Alter der Kinder sind vor allem der Erwerbsstatus der Mutter und die Dauer des Aufenthalts in Deutschland von Bedeutung. Wir sehen jedoch regionale Unterschiede in der frühkindlichen Bildungsbeteiligung, die nicht durch das kommunale Kinderbetreuungsangebot erklärt werden können.

\section{Schlagworte}

Geflüchtete, frühe Bildung, vorschulische Bildung, Kindertagessstätte, soziale Ungleichheit

\section{Introduction}

Several studies have shown that children with a migrant background do worse in primary school than those who are native-born (see, e.g., Dollmann, 2010; Gresch, 2012). Previous research has found that ethnic educational inequalities exist even before children enroll in primary school (e.g., Relikowski et al., 2015). Addressing these inequalities calls for the provision of special pedagogical support for migrant 
children, especially in learning the language of the host country, as early as possible (see, e.g., Becker \& Biedinger, 2006). Children with a migrant background benefit from attending daycare centers, and language acquisition (especially if the language that they speak at home is different from that of the host country) can be facilitated by appropriate support (Becker, 2010, 2019; Lee, Han, Waldfogel, \& Brooks-Gunn, 2018). Thus, the recommendation that children attend a daycare center as early as possible also applies to refugee children (see, e.g., von Maurice, Balaban, Will, \& Roßbach, 2020).

For refugee children in Germany, attending a daycare center often means coming into contact with the German language as well as with the cultural norms and values of the host society for the first time (see, e.g., Gambaro, Liebau, Peter, \& Weinhardt, 2017; von Maurice et al., 2020). First study results indicate that refugee children who attend daycare centers have higher German proficiency than those who do not (Schild, Welker, \& Will, in preparation). Refugee children in daycare centers can experience security and belonging as well as a child-friendly environment (Baisch, Lüders, Meiner-Teubner, Riedel, \& Scholz, 2017). Furthermore, children's attendance of a daycare center may have positive effects on their parents and families (see, e.g., Gambaro et al., 2017; von Maurice et al., 2020): In particular, the establishment of social contacts is linked to positive effects on parents' acquisition of cultural knowledge and language skills (for early evidence on this relationship, see Gambaro, Neidhöfer, \& Spieß, 2019).

Considering the current refugee immigration context, in which more than 200,000 asylum applications for children under the age of 7 were made in 20152017 alone (Federal Office for Migration and Refugees (BAMF - Bundesamt für Migration und Flüchtlinge), 2016, 2017, 2018), the question of early integration of newly immigrated children into daycare centers is particularly relevant. On the other hand, there is an open theoretical discussion on whether refugee status should be regarded as a specific subcategory of immigrant status or as a separate dimension of inequality alongside, for example, gender, social class, and immigrant background (e.g., El-Mafaalani \& Massumi, 2019). This discussion particularly relates to the fact that the contextual and individual conditions of refugees can sometimes differ drastically from those of other migrant groups.

However, until now, there have been only a few studies on refugees' educational situations, as refugee groups have not been studied thoroughly - mainly due to data limitations.

This paper aims to examine whether inequalities in the early education of refugee children can be explained by different known mechanisms of broader social and ethnic inequalities in participation in early and preschool education, and we explore whether additional refugee-specific variables (e.g., living in collective accommodation) further affect children's likelihood of attending daycare centers in particular.

We argue that known mechanisms of social and ethnic inequality in early childhood education affect refugees as well. We further argue that educational inequalities between refugee groups, i.e., from different countries of origin, and between 
refugees and other migrant groups can be explained by additional migrant- and refugee-specific variables. To test our hypotheses, we use two unique data sets from Germany.

\section{Participation of immigrants in daycare centers in Germany}

Ethnic inequality in daycare usage behavior has been well established in previous literature (for an overview see Becker \& Biedinger, 2016). The differences among three- to six-year-olds are not as pronounced as those among under-three-yearolds (see, e.g., Fuchs-Rechlin \& Bergmann, 2014; Peter \& Spieß, 2015). A comparison of the participation rates from 2009 and 2014 suggests that participation in early and preschool education is increasing overall, including among migrants, but the differences between children with and without a migrant background are still increasing slightly (see Aktionsrat Bildung, 2016, p. 124). According to recent register data, the daycare attendance rate of non-migrant children is increasing, while the corresponding rate of migrant children is stagnating or even decreasing: In 2018, 82 percent of children aged 3-6 with a migrant background were attending daycare centers, compared with 99 percent of children without a migration background. In the under-three age group, 20 percent of migrant children attended some form of childcare, compared to 41 percent of non-migrant children (Statistisches Bundesamt, 2019). However, migrants are not a homogeneous group. Peter and Spieß (2015) have shown that daycare rates vary among different migrant groups: For example, children of parents who both immigrated attend daycare centers relatively rarely.

First descriptive results on the participation of refugees in early and preschool education have shown that most 3-to-6-year-olds attend a daycare center, albeit at lower rates than native or other migrant children in this age group; for younger refugee children, the gap is even greater (Gambaro et al., 2017; Spieß, Westermaier, \& Marcus, 2016). For children whose families came to Germany in the current refugee immigration wave, attendance of daycare centers is 80 percent among 3-to-6-year-olds and 15 percent among under-3-year-olds (Gambaro et al., 2017). Furthermore, there are significant regional differences (e.g., between eastern and western Germany) (ibid; Will, Balaban, Dröscher, Homuth, \& Welker, 2018).

\section{Theoretical explanations for daycare attendance}

Sending a child to daycare can - as an educational decision - be understood as making an investment in the child's competence development by providing an appropriate learning environment (see, e.g., Becker \& Biedinger, 2016). This decision can be modeled as an interest-maximizing cost-benefit calculation that depends on 
individual motivations and resources within a given structure of opportunities and restrictions (Breen \& Goldthorpe, 1997). Different arguments can be integrated into this general theoretical model (see, e.g., Burghardt \& Kluczniok, 2016; Burghardt, 2017). Moreover, the model allows us to take into account various factors related to the social and ethnic origin as well as differences among various groups of refugees.

\subsection{Structural-level characteristics}

Childcare costs are usually comparatively low in Germany because of public funding of daycare on the one hand and cost waivers for low-income families on the other hand. Local supply of childcare is the actual challenge. Although all children older than 12 months are legally entitled to childcare, in most regions, demand for places in daycare centers cannot be satisfied. There are significant regional and local differences, with a better situation in high-income suburbs and cities (see Alt, Bergruber, \& Pötter, 2016) as well as in eastern Germany due to its history of family politics (see, e.g., Hank, Tillmann, \& Wanger 2001). Overall, there is a lower supply of childcare for children up to the age of three years (Bertelsmann Stiftung, 2019). Previous studies have already shown that individual daycare attendance is significantly related to daycare supply (Fuchs-Rechlin \& Bergmann, 2014; Geier \& Riedel, 2008).

A low childcare rate is associated with problems finding daycare for families with and without a migration background. While migrants tend to live in metropolitan areas in western Germany and in larger cities in general, refugees are distributed more evenly across Germany and are also housed in rural areas and eastern Germany due to regulations allocating the hosting of refugees across the country (see BAMF, 2018). Thus, controlling for the regional supply of daycare may explain the differences in daycare attendance between migrants and natives to a greater extent than the differences between refugees and natives.

Concerning legal access, the time at which refugee children become entitled to receive childcare is a point of controversy (see Baisch et al., 2017). In most federal states, entitlement is granted if the child has been assigned to be hosted by a municipality in the respective federal state (see Deutsches Institut für Menschenrechte, 2017). Thus, regardless of their legal residence status and their residence within collective or private accommodation, refugee children are entitled to receive childcare from the age of one if they are no longer in an initial reception facility. ${ }^{1}$

1 However, it remains unclear whether children in so-called "AnkER-Zentren", which were established from 2018 in some federal states, are treated in practice like children in initial reception facilities. AnkER-Zentren are facilities in which asylum seekers initially are accommodated until their asylum application is decided and they are either assigned to be hosted in a certain municipality or obligated to return to their country of origin. 


\subsection{Mechanisms related to socioeconomic background}

Parents of higher social classes tend to choose daycare centers more often than parents of lower social classes. More highly educated parents know more about the possibilities and positive effects of early preschool education than less educated parents (Becker \& Lauterbach, 2007; Becker \& Tremel, 2006). In addition, higher-earning parents can afford childcare more easily (Becker \& Tremel, 2006). Although costs are lower in absolute terms for low-income families, families at risk of poverty who have daycare expenses still pay almost as much in relation to their income as other households (see Schmitz, Spieß, \& Stahl, 2017). It is well established that mothers' employment status is central to explain daycare attendance. Also, more highly educated mothers demand more childcare because of their higher opportunity costs of staying at home (Becker \& Tremel, 2006; Kreyenfeld \& Krapf, 2010).

In previous studies, ethnic differences in daycare attendance have been largely explained by differences in socioeconomic background (for an overview, see Becker \& Biedinger, 2016). Migrants use daycare centers less than the population overall largely because of their lower socioeconomic status and lower levels of education. For older migrant children, in particular, there is hardly any difference from the native population in terms of daycare attendance after socioeconomic background is controlled for, while significant differences remain in the group of children under the age of three (see, e.g., Fuchs-Rechlin \& Bergmann, 2014; Kreyenfeld \& Krapf, 2010).

We assume that these mechanisms should also affect refugee families; however, it is conceivable that the effects on refugees could initially be weaker for various reasons. For example, the desire to take up gainful employment should be more pronounced among educated refugee women than among less educated refugee women as well. However, due to a lack of German language skills and possible legal barriers to labor market entry (e.g., recognition of foreign qualifications, work permits, restricted choice of place of residence), it is mostly not possible for refugees to directly take up employment after entering the country.

\subsection{Migrant-specific mechanisms}

Knowledge, or a lack thereof, has been argued to explain ethnic differences in daycare attendance because immigrants may have less knowledge of the availability of early childcare offers due to foreign socialization (see, e.g., Stichs \& Rotermund, 2017). Differences in knowledge may also relate to other aspects, such as knowledge of possible cost waivers or legal entitlement to the use of such waivers. Social contacts with natives might help immigrants acquire knowledge of the education system (ibid.) or directly support them in the process of registering their children in a daycare center (see Baisch et al., 2017). 
Parents' low German language proficiency is another important driver of ethnicity-based differences. In particular, children of mothers with low language proficiency attend daycare centers significantly less (e.g., Becker \& Tremel, 2006). Poor German proficiency not only can be seen as an indicator of little knowledge of the education system in the host country but also may lower the chances that mothers make use of their childcare entitlements.

These factors, which can also be described as a lack of host country-specific cultural capital, should be especially relevant for newly arrived immigrants. As all refugee families, which we consider in this article, are first-generation immigrants, the variables mentioned in the section above should apply in particular to this immigrant group as well.

Cultural differences may also explain different daycare attendance rates (see, e.g., Fuchs-Rechlin \& Bergmann, 2014; Sachverständigenrat deutscher Stiftungen für Integration und Migration, 2013). In particular, due to a more traditional gender division of labor in migrant families, women are less likely to be employed and to need daycare. In addition, in some countries of origin, daycares are less common, and care outside the family might therefore be less accepted (see Die Beauftragte der Bundesregierung für Migration, Flüchtlinge und Integration, 2011; for data on participation in preschool education in Syria, see World Bank, 2015).

Presumably, cultural differences wane over the course of generations. However, for first-generation migrants and thus for the refugees who arrived in recent years, the cultural ideas of the society of origin should still be prominent.

Last, it cannot be completely ruled out that admission practices in individual daycare centers are related to the lower daycare attendance of migrant children (see, e.g., Alt et al., 2016).

\subsection{Refugee-specific mechanisms ${ }^{2}$}

In addition to all the previously discussed drivers, some factors could contribute to explaining daycare attendance rates among refugee children specifically.

First, refugee children who have had traumatic experiences might have developed posttraumatic stress disorder (PTSD). In these cases, parents might hesitate to use daycares. However, it has been argued that the experience of traumatic events can lead refugees to be more motivated to remain in the host country (see, e.g., Hunkler \& Khourshed, 2020) and thus to make special efforts to integrate.

Second, as refugee migration is a forced and nonvoluntary act, refugees might have a higher return orientation than other immigrant groups. An intention to return to one's home country reduces the benefits of investing in host country-spe-

2 The factors described in this section are, strictly speaking, specific aspects of ethnic inequality. However, as the described mechanisms are - due to the general conditions of forced migration and the specific characteristics of this immigrant group - particularly applicable to refugees, we summarize them as refugee-specific factors. 
cific capital, in particular, the German language. Refugees may therefore consider regular attendance of a daycare center less beneficial for their children.

The same reasoning could apply if refugees have not received a secure residence status and therefore perceive their stay in the host country to be temporary. From the official side, as mentioned in section 3.1, there are no daycare access barriers based on residence status or type of accommodation after refugee children have left the initial reception facility. However, it cannot be ruled out that actual daycare center enrollment practices may cause problems in the admission of newly arrived migrants and therefore also for our specific target group. For example, Baisch et al. (2017, p. 24) state that inflexible admission regulations (e.g., allowing admission only at certain times of the year or on a first-come-first-served basis) can present access barriers for immigrant families.

\subsection{Summary of hypotheses}

Table 1 summarizes our hypotheses and what contribution the individual factors should make in explaining group differences in daycare attendance between people with and without a migration background and refugees.

Table 1: Hypotheses on daycare center attendance and group differences

\begin{tabular}{ll}
\hline Hypotheses on basic variables & Effects on group differences \\
\hline Structural variables: & \\
$\begin{array}{ll}\text { Hypothesis 1: Regional undersupply of daycare has } \\
\text { a negative impact on daycare attendance. }\end{array}$ & $\begin{array}{l}\text { Differences between natives and migrants, in par- } \\
\text { ticular, should decrease. Additionally, differences } \\
\text { between natives and refugees should decrease, but } \\
\text { to a smaller extent. }\end{array}$ \\
\hline
\end{tabular}

Socioeconomic variables:

Hypothesis 2: Children from families with a more privileged socioeconomic background are more likely to attend daycare.
Differences between natives and migrants, in particular, should decrease. Additionally, differences between natives and refugees should decrease, but to a smaller extent.

Migrant-specific variables:

Hypothesis 3: Social contact with natives is positively associated with daycare attendance.

Hypothesis 4: German language proficiency is positively associated with daycare attendance.

Hypothesis 5: Children from families with fewer host country-specific cultural resources are less likely to attend daycare.

Hypothesis 6: Children from families with more traditional gender attitudes are less likely to attend daycare.
Differences among different migrant groups (including different refugee groups) should decrease.

Differences among different migrant groups (including different refugee groups) should decrease.

Differences between migrants and refugees, in particular, should decrease.

Differences among different migrant groups (including different refugee groups) should decrease. 


\begin{tabular}{|c|c|}
\hline Hypotheses on basic variables & Effects on group differences \\
\hline \multicolumn{2}{|l|}{ Refugee-specific variables: } \\
\hline $\begin{array}{l}\text { Hypothesis 7a: Children at risk of posttraumatic } \\
\text { stress disorder are less likely to attend daycare. }\end{array}$ & $\begin{array}{l}\text { Differences among refugee groups should decrease. } \\
\text { However, the direction of the effect is unclear. }\end{array}$ \\
\hline \multicolumn{2}{|l|}{$\begin{array}{l}\text { Hypotheses } 7 \mathrm{~b} \text { : Children at risk of posttraumatic } \\
\text { stress disorder are more likely to attend daycare. }\end{array}$} \\
\hline $\begin{array}{l}\text { Hypothesis 8: Children from families with a high } \\
\text { return orientation are less likely to attend daycare. }\end{array}$ & $\begin{array}{l}\text { Differences among different refugee groups should } \\
\text { decrease. }\end{array}$ \\
\hline $\begin{array}{l}\text { Hypothesis 9a: Residence status has no effect on } \\
\text { daycare attendance. } \\
\text { Hypothesis 9b: An insecure residence status reduc- } \\
\text { es the probability of daycare attendance. }\end{array}$ & $\begin{array}{l}\text { Whether the residence status contributes to differ- } \\
\text { ences between various refugee groups cannot be } \\
\text { clearly predicted from the contradictory theoretical } \\
\text { arguments. }\end{array}$ \\
\hline
\end{tabular}

\section{Data and methods}

To analyze refugee children's daycare attendance, we use data from two data sets, the IAB-BAMF-SOEP Survey of Refugees in Germany³ (see Kühne, Jacobsen, \& Kroh, 2019) and the Refugees in the German Educational System (ReGES) study (Will, Gentile, Heinritz, \& von Maurice, 2018). In both studies, parents were the main respondents. The interviews were conducted during the 2017-2018 school year; the SOEP interviews were conducted at the end of 2017, and the ReGES interviews were conducted at the beginning of 2018 .

\subsection{SOEP data}

The IAB-BAMF-SOEP Survey of Refugees in Germany consists of different subsamples of asylum seekers and refugees who arrived in Germany between January 2013 and December 2016. All subsamples were drawn from the Central Register of Foreigners. Altogether, 4,855 households were interviewed, resulting in 6,779 faceto-face interviews with adults and information on 5,942 children in the interviewed households in the initial interview. However, for the subsample of refugees in the analysis, only families who migrated to Germany since January 1, 2014, or thereafter were included.

As the data of the IAB-BAMF-SOEP Survey of Refugees in Germany were incorporated into the regular Socio-Economic Panel (SOEP) study (Goebel et al., 2019), they provide a basis for comparisons with other migrant groups in Germany as

3 The Institute for Employment Research (IAB), the Migration, Integration and Asylum Research Center at the Federal Office for Migration and Refugees (BAMF-FZ), and the Socio-Economic Panel (SOEP) joined together in a cooperative longitudinal project to survey a nationwide random sample of refugee households in Germany in late 2015: the IAB-BAMF-SOEP Survey of Refugees. We use v34 of the data. 
well as with individuals without a migrant background who are part of the regular SOEP study.

Our analysis samples consist of $n=1,215$ non-migrants, $n=1,001$ migrants, and $n=2,007$ refugees. 4 We analyze two subgroups: children up to three years old and children aged three to six years but below school age. While all refugee children in the older age group were foreign-born, we also classify children in the younger age group as refugees if they were born in Germany, but their parents immigrated as refugees on January 1, 2014, or thereafter.

\subsection{ReGES data}

While the SOEP provides representative data on households, the ReGES study focuses explicitly on two refugee cohorts facing important educational transitions in the German education system. One of these cohorts includes 2,405 children aged four years or older who were not yet attending school at the time of the initial interview and whose parents were interviewed face-to-face.

The survey is being conducted in the five federal states of Bavaria, Hamburg, North Rhine-Westphalia, Rhineland-Palatinate, and Saxony. These states were systematically selected using various macro-level indicators (e.g., the share of assigned refugees, labor market conditions, and population density) (for more details on the study design see Will et al., 2018b).

In contrast to the SOEP, the ReGES sample was drawn from 120 municipalities selected based on the Central Register of Foreigners. Local registration offices provided the addresses of children in the relevant age groups who had moved to the municipality after January 1, 2014, and who were nationals of one of the current main countries of origin of asylum seekers with a high protection rate and who had been living in Germany for at least three consecutive months (for details on the sampling procedure, see Steinhauer, Zinn, \& Will, 2019).

Our analysis sample consists of $n=2,183$ children between ages four and six who had not yet started school at the interview date.

4 We used the variables migback, arefback, immiyear and gebjahr provided by the SOEP SUF (methodology report) to generate our group variables (see for details SOEP Group, 2019). According to migback, natives are children born after 2010 without a migration background (both the child and both parents were born in Germany). Migrants are children born after 2010 with a direct or indirect migration background according to migback and without a refugee background according to arefback (reason for immigrating was something other than flight and asylum). According to arefback, refugees are children born after 2010 with a direct or indirect refugee background who immigrated to Germany in 2014 or thereafter (for those at least three years old) or whose parent immigrated in 2014 or thereafter (for those younger than three years old). 


\subsection{Operationalization and methods}

For the analysis of elementary education in the age range of $0-3$ (younger than 36 months), we use the SOEP data and for the age range 3-6 (36 months and older), we use both the SOEP and the ReGES data. ${ }^{5}$ The SOEP data cover a representative German sample and allow comparison of refugees with the majority population and other migrant groups. The ReGES data provide additional information on the refugee-specific factors that we theorize to be influential in refugees' educational integration and allow us to examine differences among major refugee groups. For the 3-6 age group, we exclude all children who were of school age in the school year 2017/18 because we expect a strong selection effect from delayed school enrollment that would lead to biased results.

Our dependent variable is daycare attendance. We estimate linear probability models (LPMs) with robust standard errors because of the simple interpretation of the regression coefficients as changes in percentage points of the likelihood of attending daycare. We use a stepwise analysis approach, including another variable group in each step, and run the analyses separately for both data sets first to analyze how refugees' and other migrants' daycare attendance differs from that of natives; second, using the SOEP data, to examine how refugees in both age groups differ from migrants; and third, using SOEP data for o-to-3-year-olds and SOEP and ReGES data for 3-to-6-year-olds, to evaluate how refugee groups differ from each other. Table A1 in the appendix provides information on the distributions of all the variables used for all subsamples.

Structural factors are operationalized by three variables. We use district size and federal state to control for different local and regional regulations. Additionally, we use the district-level attendance rate of all children in the $0-3$ and $3-6$ age groups who attend any form of childcare center as a proxy for the local provision of daycare places.

Socioeconomic background is operationalized by two main indicators: highest parental education level and highest family socioeconomic status. Parental education is measured on the International Standard Classification of Education (ISCED) scale. Socioeconomic status is measured on the International Socio-Economic Index of Occupational Status (ISEI) scale. We add a control for parents who have never been employed in Germany. As most of the refugees had not yet been employed in Germany at the time of the interview, we include the highest ISEI (HISEI) based on their employment in their countries of origin as well as a control for those who had never been employed in their countries of origin. In the ReGES analyses, we additionally include the number of books in the home in respondents' countries of origin as an internationally established indicator of sociocultural back-

5 We used multiple imputation to deal with missing data (for details, see the end of section 4). Due to high rates of missing data (which varied by group: natives $=20.6 \%$, migrants $=13.6 \%$, refugees $=63.6 \%$ ) on children's birth months in the SOEP data, child age is a partially imputed variable. Therefore, the analysis samples varied in terms of the level of imputation. The alternative of including only cases with complete date information would certainly lead to biased results due to selection effects. 
ground, and in the SOEP analyses, we include the current monthly family income, measured in income groups, as a quasi-metric variable. Furthermore, we control for the mothers' current employment.

Migrant-specific factors are included in the form of several variables: The self-rated German language proficiency of both parents separately is included as a z-standardized factor score of the subdomains of speaking, reading, and writing $(\mathrm{M}=0, \mathrm{SD}=1$; the original scale was $1=$ "not at all" to $5=$ "very good"; Cronbach's alphas range between 0.95 and 0.96). Additionally, in the SOEP analyses, we include a dummy indicator for whether the language spoken in the family is not German. To capture information deficits and initial legal barriers after immigration, we include the length of stay (in years) in Germany as a metric variable. Unfortunately, it is only possible to evaluate this variable for refugees, as the SOEP sample does not include any new immigrants who immigrated to Germany for reasons other than asylum in the age groups under six years. Thus, to control for host-specific knowledge and cultural convergence over the course of generations, we additionally include non-refugee migrants in these analyses if their parents either immigrated themselves or were born in Germany. Furthermore, we consider social contact with natives, measured on a six-point quasi-metric scale (from $1=$ "never" to $6=$ "daily contact") for the refugee samples. To test for the hypothesized impact of cultural differences, we include religiosity as a proxy for internalization of cultural norms in general but also as a proxy for traditional gender roles ${ }^{6}$ in particular. The indicator was measured on a 4-point scale (from $1=$ "not at all religious" to 4 = "very religious") and entered as quasi-metric. Additionally, in the SOEP analyses, we include frequency of attendance of religious events and gatherings (on a quasi-metric scale from $1=$ "never" to 4 = "at least once a week"). In the ReGES analyses, we include a dummy indicator for whether the child had ever attended daycare before immigration. This indicator is a proxy for knowledge of the positive effects of early preschool education on the one hand and cultural openness on the other hand.

To account for refugee-specific variables, we include return orientation as an indicator of whether respondents reported wanting to stay forever in Germany or to leave in the near future or at some point in the future (dummy). To test the effect of residence status, we split our sample into persons with a relatively secure status (recognized as refugees or as entitled to asylum) on the one hand and persons with a different protection status or persons whose application for asylum was denied on the other hand (dummy). Furthermore, we include an indicator for families that still lived in collective accommodation (dummy). In both data sets, three refugee groups are large enough to be analyzed separately: Afghans, Iraqis, and Syrians. All other groups are collapsed into the residual Other category. In this way, it is possible to control for systematic differences (e.g., other cultural differences) not covered by other covariates.

6 There is a measure for gender roles included in the ReGES data but not in all the SOEP subsamples that we use. 
In the ReGES analyses, we additionally include children's PTSD risk, measured by an adaptation of the Process of Recognition and Orientation of Torture Victims in European Countries to Facilitate Care and Treatment (PROTECT) questionnaire (Boillat \& Chamouton, 2013) into a rating of ten PTSD symptoms reported by their parents and included as a z-standardized factor score $(\mathrm{M}=0, \mathrm{SD}=1$; Cronbach's alpha $=0.64)$.

Additional controls for the number of siblings, single-parent families, and the child's gender and age (in months) are included in both data sets.

To cope with missing data from item nonresponse, we impute missing data for all the independent variables using multiple imputations by chained equations with fully conditional specification and predictive mean matching (see Buuren, 2018). The values for the different subgroups (natives, migrants, and refugees) are imputed separately, and the data sets are combined afterward. In the resulting $\mathrm{m}=100$ data sets, we exclude cases with imputed outcome data and analyze them using Rubin's rules (see Rubin, 1987).

\section{Results}

The results for the comparison of refugees and other migrants with natives in the o-3 age group are presented in Table 2a. In Model 2a-1, we replicate previous findings of migrants' lower daycare attendance rates, especially at this early age (-9.0 percentage points, $\mathrm{p}<0.05)$. Furthermore, we find an even lower attendance rate for refugees (-20.4 percentage points, $\mathrm{p}<0.01)$. In Model 2a-2, we include basic demographic and family control covariates (number of siblings, single-parent family indicator, and child's gender and age), which are important predictors and which already explain part of the differences in the attendance rates of refugees and other migrants. In Model 2a-3, we test Hypothesis 1 and include structural factors such as daycare supply, district size, and federal state dummies. In line with our expectations, these drivers largely explain the lower probabilities for migrants (which drop below the 95 percent significance level) and partially explain those for refugees. In Model 2a-4, we test Hypothesis 2 and control for socioeconomic background, which explains the remaining differences we find for refugees. However, neither families' current social status nor parental education effect the probability of daycare attendance. Only the indicator for whether the parents have never or have not yet worked in Germany is negatively associated with the probability of attending daycare. This result remains stable under control of family income (see Model 2a-5), but loses significance as soon as we control mothers' economic integration (Model 2a-6). Overall, employment of mothers has the strongest effect on attendance probability among all the variables. ${ }^{7}$

7 We also run analyses with mothers' working hours instead. The results were the same as those based on the dummy variable for both age groups. 
The results of the comparison of refugees and other migrants with natives in the 3-6 age group are presented in Table $2 b$. In Model $2 b-1$, we also replicate previous findings of daycare attendance for this age group. As in the lower age group, migrant children have a lower attendance probability than that of natives. Notably, while the difference for migrants is less than half of that for the lower age group ( -3.8 percentage points, $\mathrm{p}<0.05)$, for refugee children, we find a similar difference in attendance probability also for the 3-to-6-year-olds (-18.2 percentage points, $\mathrm{p}<0.01$ ). In Model $2 \mathrm{~b}-2$, we include demographic and family controls, and in Model 2b-3, we include our structural variables to test Hypothesis 1. Unlike for the younger age group, for the older age group, these macro indicators do not substantially help to explain the differences across the three subsamples. This might be traced back to the fact that daycare supply for older children is uniformly well established. ${ }^{8}$ In Model $2 \mathrm{~b}-4$, we included our variables to measure socioeconomic background, which explain the remaining difference for the migrant group ( $>0.05$ ) and nearly half of the remaining difference for the refugee group. As in the younger age group, this result is driven not by educational differences but by family income and above all different levels of mothers' labor market participation, as seen in Model 2b-5 and 2b-6. However, in contrast to the result for the younger age group, not all of the difference in attendance rates between refugees and natives for the 3-to-6-year-olds can be explained in this way.

In the next step, we examine whether migration-specific variables help explain the different daycare attendance rates among different groups of migrants. The results of the analysis of differences between migrants and refugees to test the migrant-specific hypotheses are presented in Table $3 \mathrm{a}$ (o-to-3-year-olds) and Table $3 \mathrm{~b}$ (3-to-6-year-olds). The first six models each (Models $3 \mathrm{a}-1$ to $3 \mathrm{a}-6$ and $3 \mathrm{~b}-1$ to $3 \mathrm{~b}-$ 6) replicate the analyses with natives by starting with the unconditional differences among the groups and then adding the demographic, structural, and socioeconomic variables. Differences among the groups can be explained by these factors in both age groups. In the next two models each (3a-7, 3a-8, 3b-7, 3b-8), we test our hypotheses concerning migrant-specific mechanisms of daycare attendance. While we find no supporting evidence for Hypotheses 4 (language proficiency) and 6 (traditional gender attitudes), we find slight corroborating evidence for Hypothesis 5 (acquisition of host country-specific capital) in the younger age group: Children whose parents were born in Germany are more likely to attend daycare centers $(p<0.10)$.

The consideration of refugee-specific factors may provide deeper insight into aspects that may foster or hinder the daycare attendance of refugee children. The results of the analysis for the two refugee samples in the SOEP data are presented in Tables $4 \mathrm{a}$ and $4 \mathrm{~b}$. The results of the comparison of SOEP and ReGES data

8 There are, however, minor differences in daycare attendance (by up to 5-7 percentage points) between some federal states. For the younger age group, the federal state differences are even more pronounced, and attendance rates are significantly higher in most eastern states than in most western states. This is due to the historically higher daycare supply in the former German Democratic Republic (results are shown in Table A4 in the appendix). 
are presented in Table 5 . The models mostly show results with a set of harmonized variables. Only in Models 5-R4a, 5-6a, 5-R7a, and 5-R8 additional variables are included which are available only in the ReGES data. In the first model for each age-group (Models 4a-1, 4b-1, 5-S1, and 5-R1), we analyze unconditional differences between refugee (i.e., ethnic) groups. Over the two age groups and samples, we observe no systematic patterns between the ethnic groups. In the SOEP data on the younger age group, Iraqi children are more likely to attend daycare, while in the older age group, Afghani children are more likely to do so. In the ReGES sample, Afghan children are less likely to attend daycare than Syrian children (who are the reference group in all subsamples). However, the effects are not particularly robust and lose their statistical significance in subsequent models with additional controls. In Models 4a-3, 4b-3, 5-S4, and 5-R4, we control for structural factors that impact attendance rates. In contrast to the analysis that includes natives and other migrants, in the analyses with the refugee-only sample, the daycare attendance rate at the district level is significantly associated with refugee daycare attendance in the age group of 3-to-6-year-olds. This indicates that the supply of places in daycare centers is very important for the inclusion of refugee children. In Models 5 - $\mathrm{S}_{3}$, 5 -R3, and 5 -R3a, we control for social origin, and we find the effects predicted by Hypothesis 2. Children with parents who had a higher class position in their country of origin and with parents who are more highly educated are more likely to attend daycare, even if these effects only display statistical significance in some of our analyses. Contrary to expectations, in both data sets, children of parents who never worked in their home countries have a higher chance of attending daycare. The question of whether this effect may be driven by young parents who want to continue their education in Germany cannot be answered at this time. With the ReGES data, we find the expected effects of migrant-specific factors in Models 5-R6 and 5-R6a. Children whose parents have higher German proficiency are more likely to attend daycare. As we use cross-sectional data, the direction of this association is unclear because parents whose children attend daycare have more contact with German-speaking children, other parents, and educators, which would in turn likely improve the parents' German proficiency. Our results also confirm the prediction of Hypothesis 5 that the longer refugees' stay in Germany, the greater is the likelihood of daycare attendance. The length of stay in Germany has a clear positive effect in both data sets. The effect, however, is statistically significant only for 3 -to6-year-olds. Last, in Models 5-S7, 5-R7, and 5-R7a, we control for refugee-specific variables. Neither legal status nor the type of accommodation has a significant impact on refugee children's probability of attending daycare. Only PTSD risk shows a significant association with daycare attendance; the positive sign contradicts the prediction of Hypothesis $7 \mathrm{a}$ but corroborates that of Hypothesis $7 \mathrm{~b}$. However, it must again be noted here that this could be driven by reversed causality, as parents might be made aware of their children's PTSD risk through interaction with preschool teachers. Furthermore, symptoms similar to those of PTSD may occur due to the stress that all children face when they transition into daycare. 
The role of socioeconomic, cultural, and structural factors in daycare attendance |

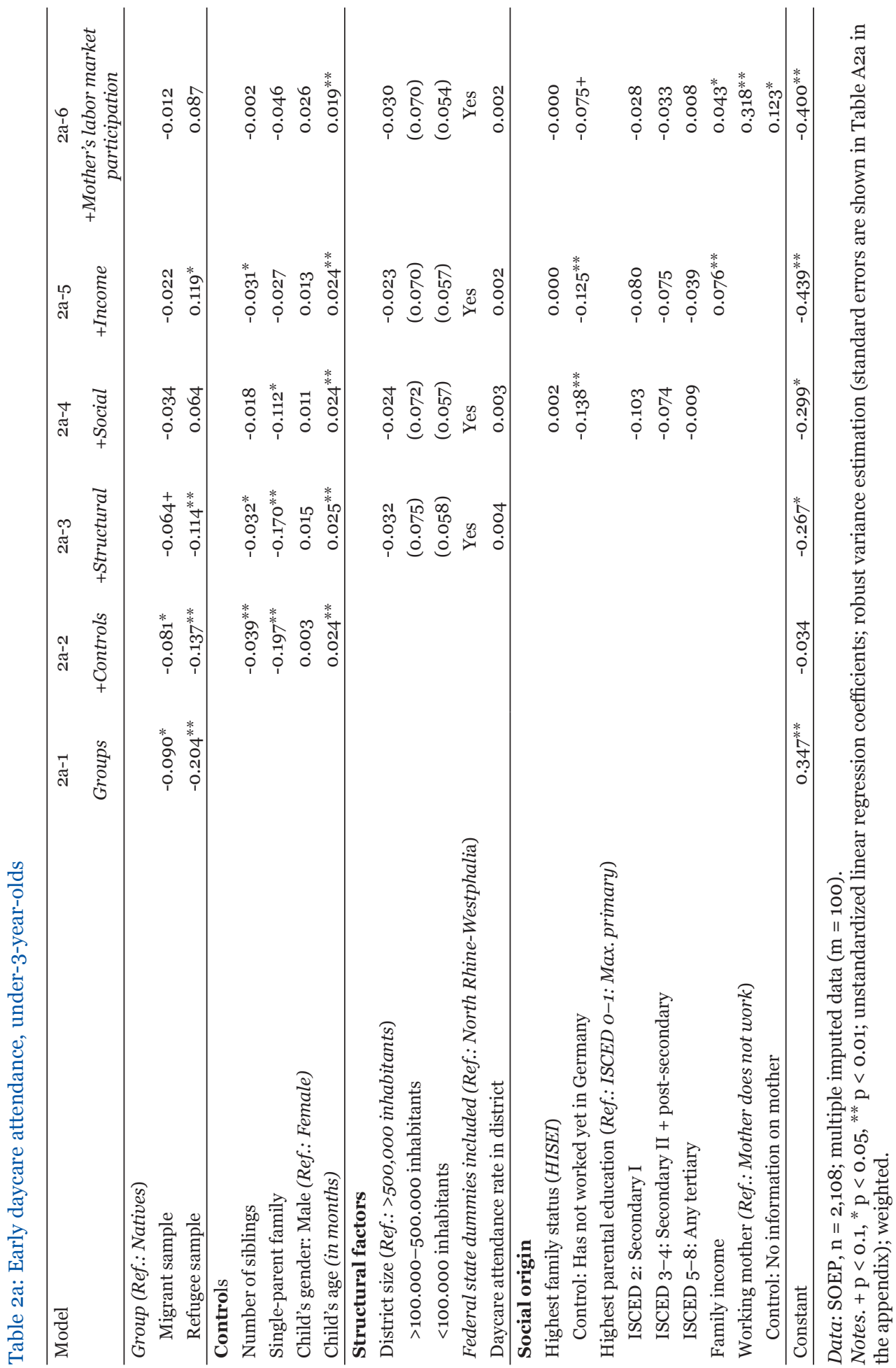


| Christoph Homuth, Elisabeth Liebau \& Gisela Will

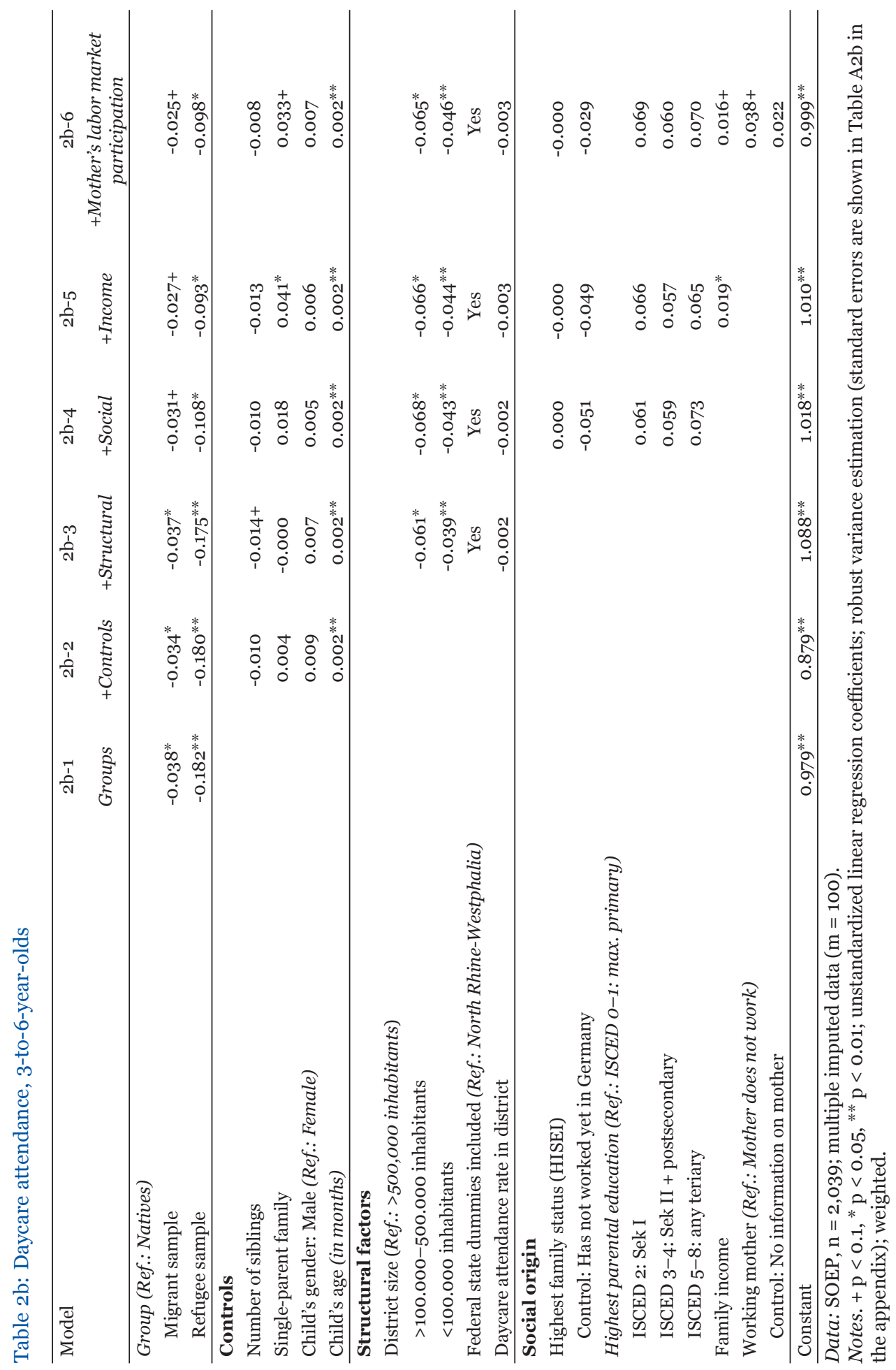

32 JERO, Vol. 13, No. 1 (2021) 
The role of socioeconomic, cultural, and structural factors in daycare attendance |

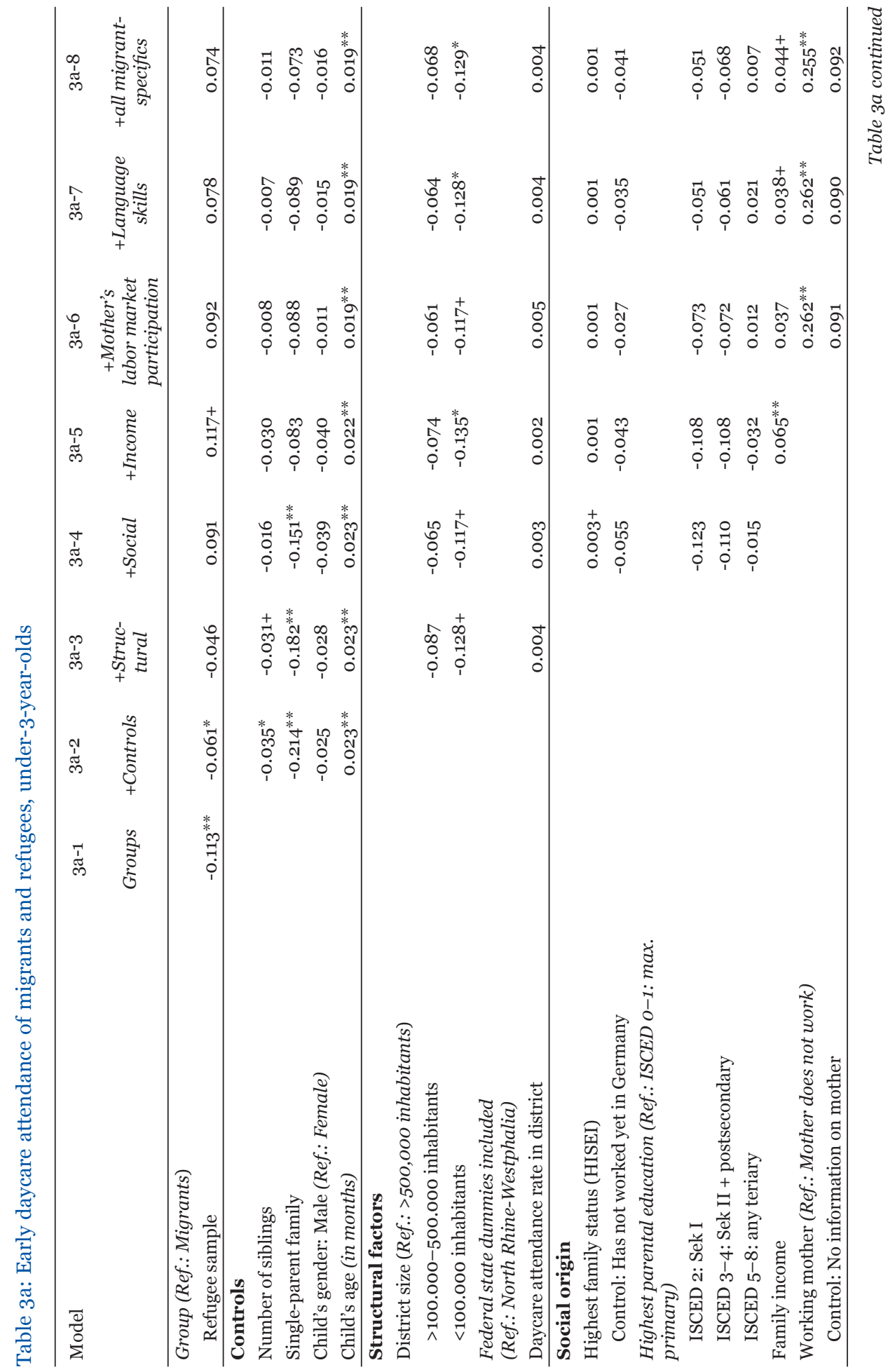


| Christoph Homuth, Elisabeth Liebau \& Gisela Will

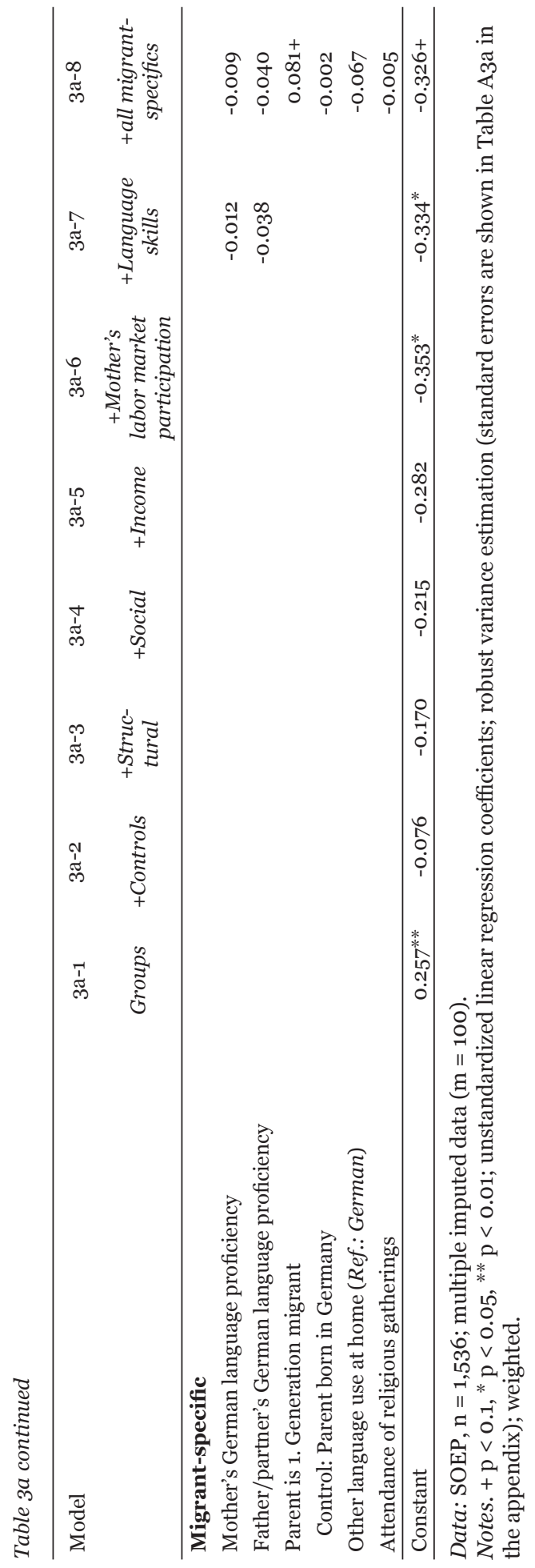

34 | JERO, Vol. 13, No. 1 (2021) 
The role of socioeconomic, cultural, and structural factors in daycare attendance |

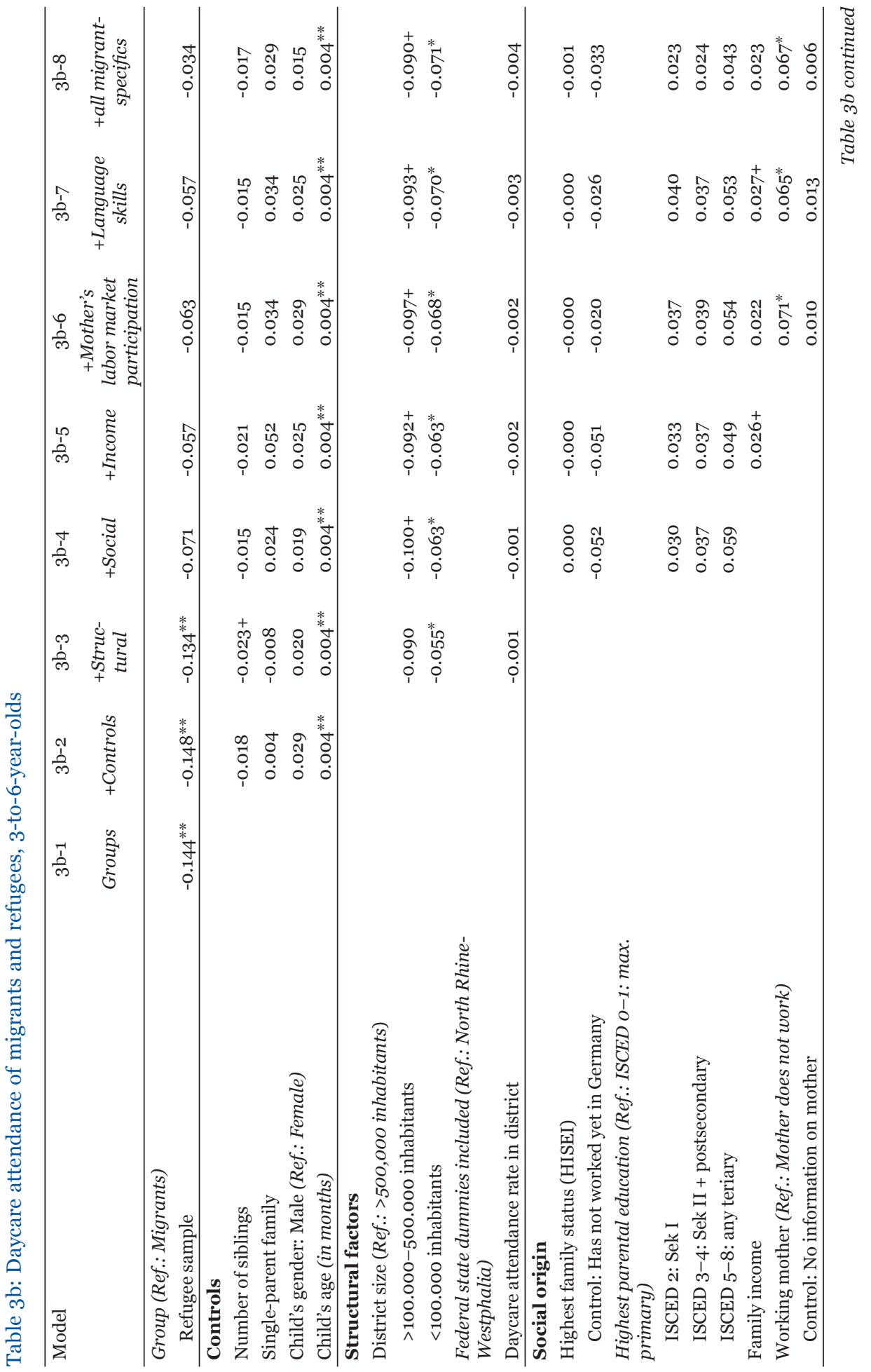


| Christoph Homuth, Elisabeth Liebau \& Gisela Will

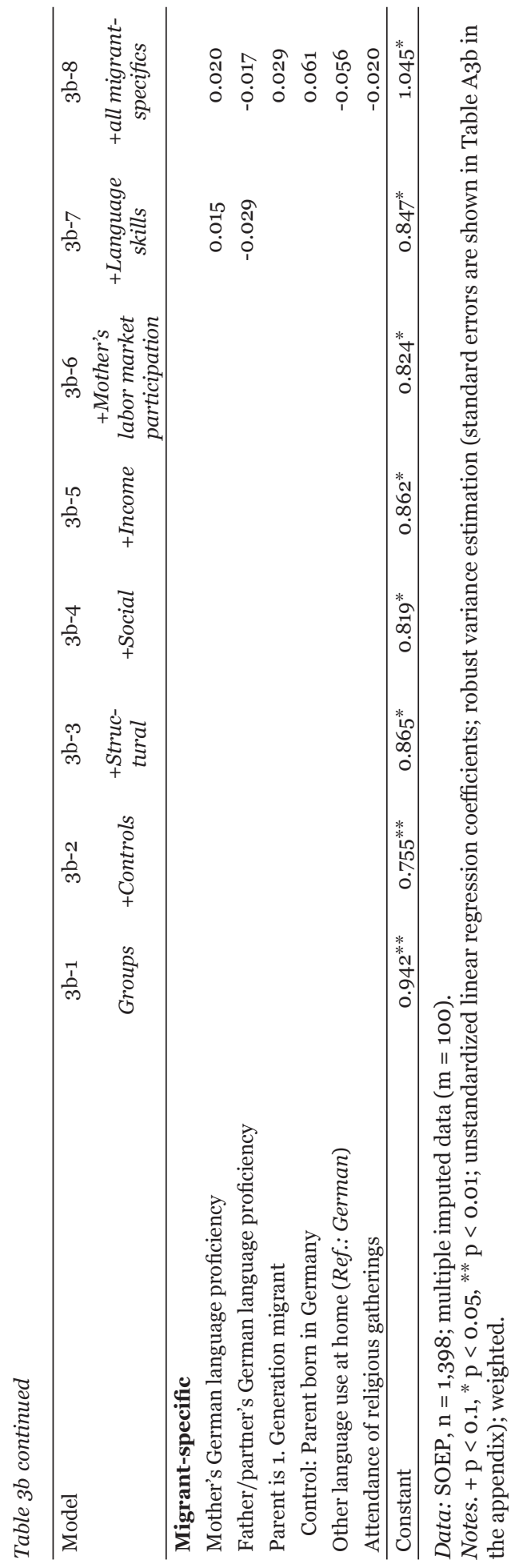

36 | JERO, Vol. 13, No. 1 (2021) 
The role of socioeconomic, cultural, and structural factors in daycare attendance |

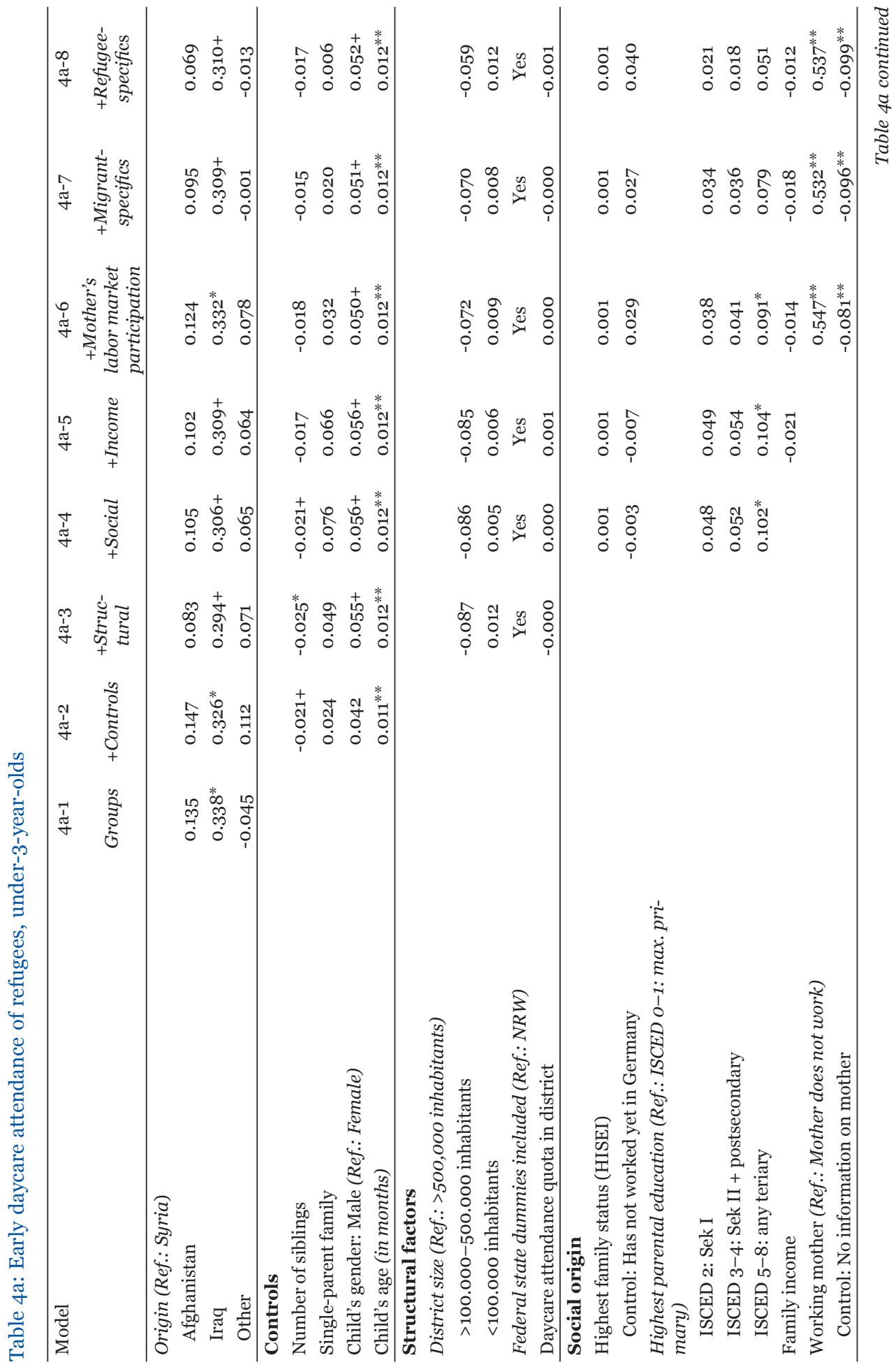


| Christoph Homuth, Elisabeth Liebau \& Gisela Will

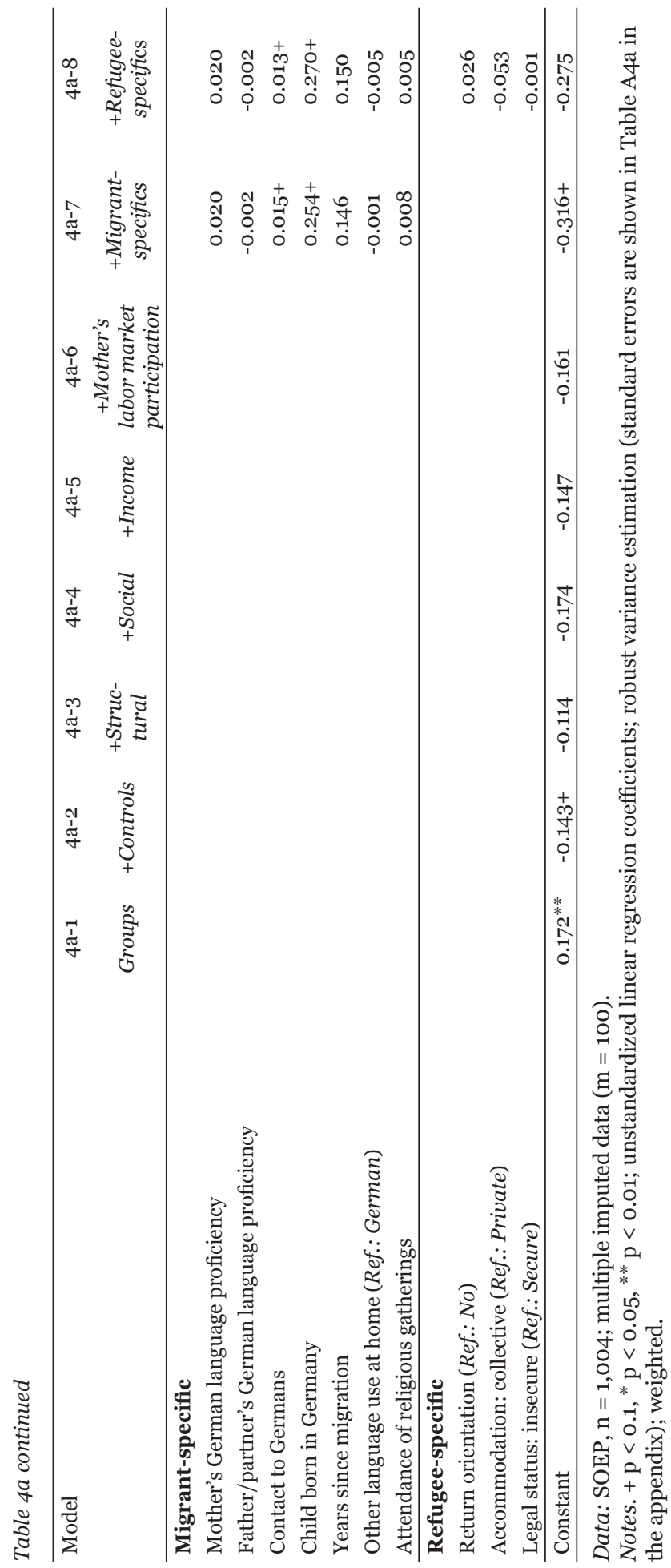

38 | JERO, Vol. 13, No. 1 (2021) 
The role of socioeconomic, cultural, and structural factors in daycare attendance |

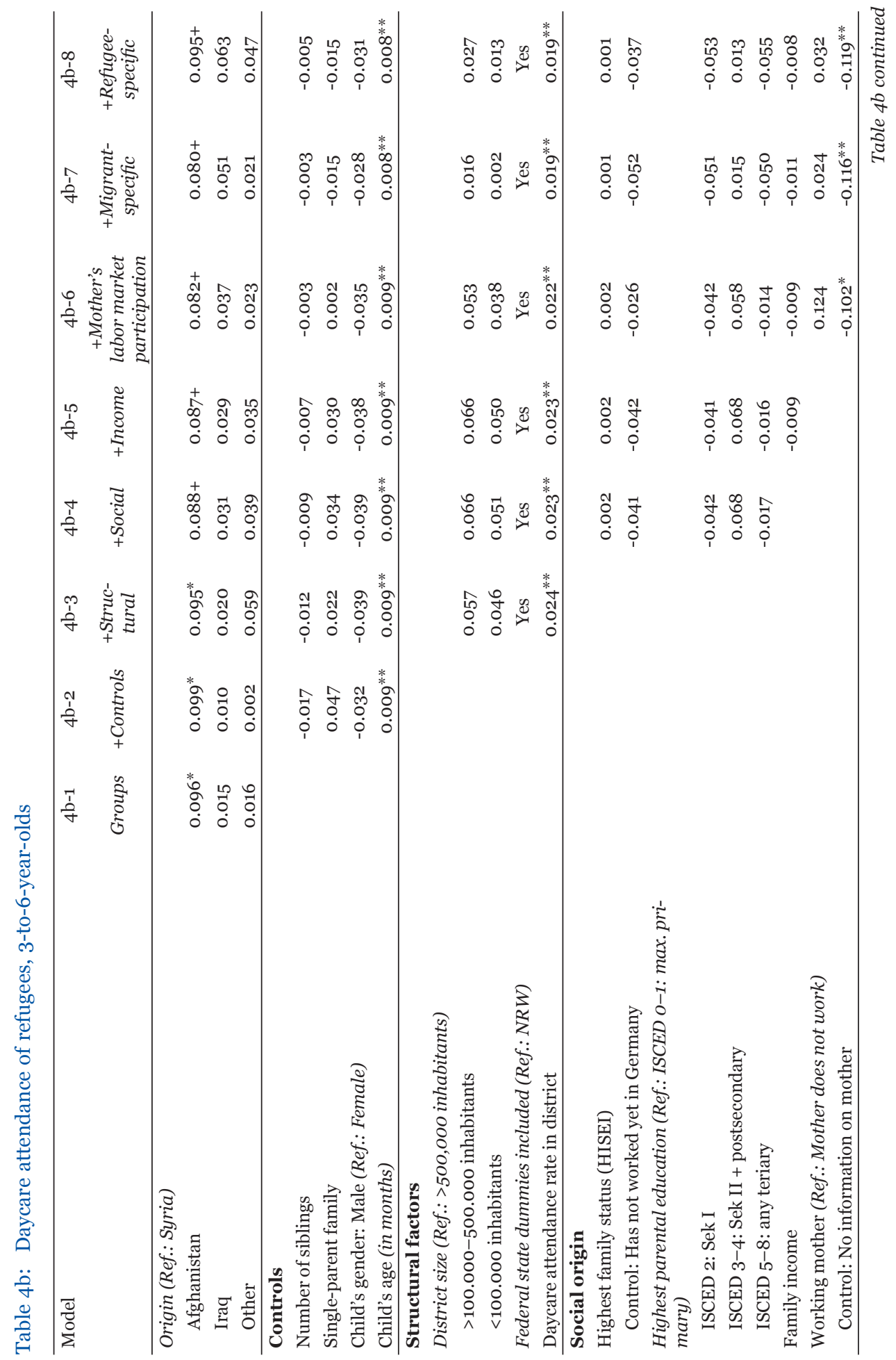


| Christoph Homuth, Elisabeth Liebau \& Gisela Will

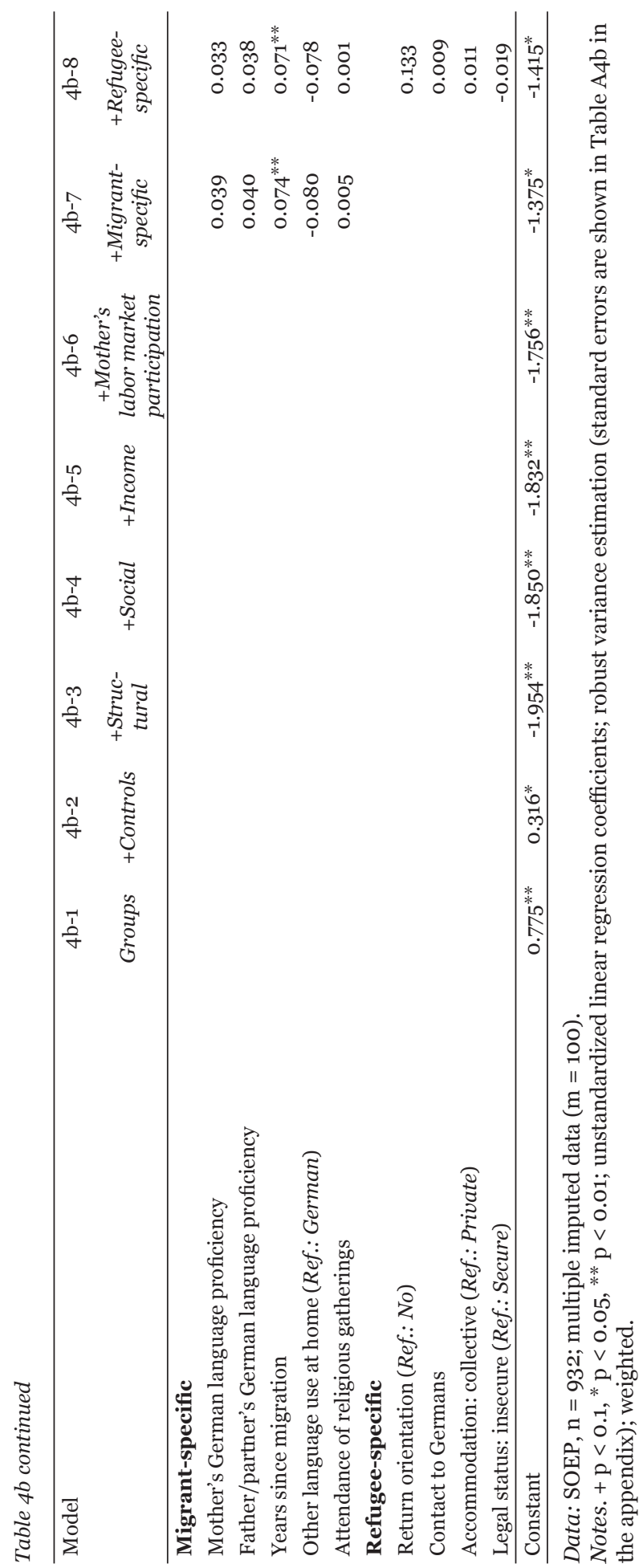

40 | JERO, Vol. 13, No. 1 (2021) 
The role of socioeconomic, cultural, and structural factors in daycare attendance |

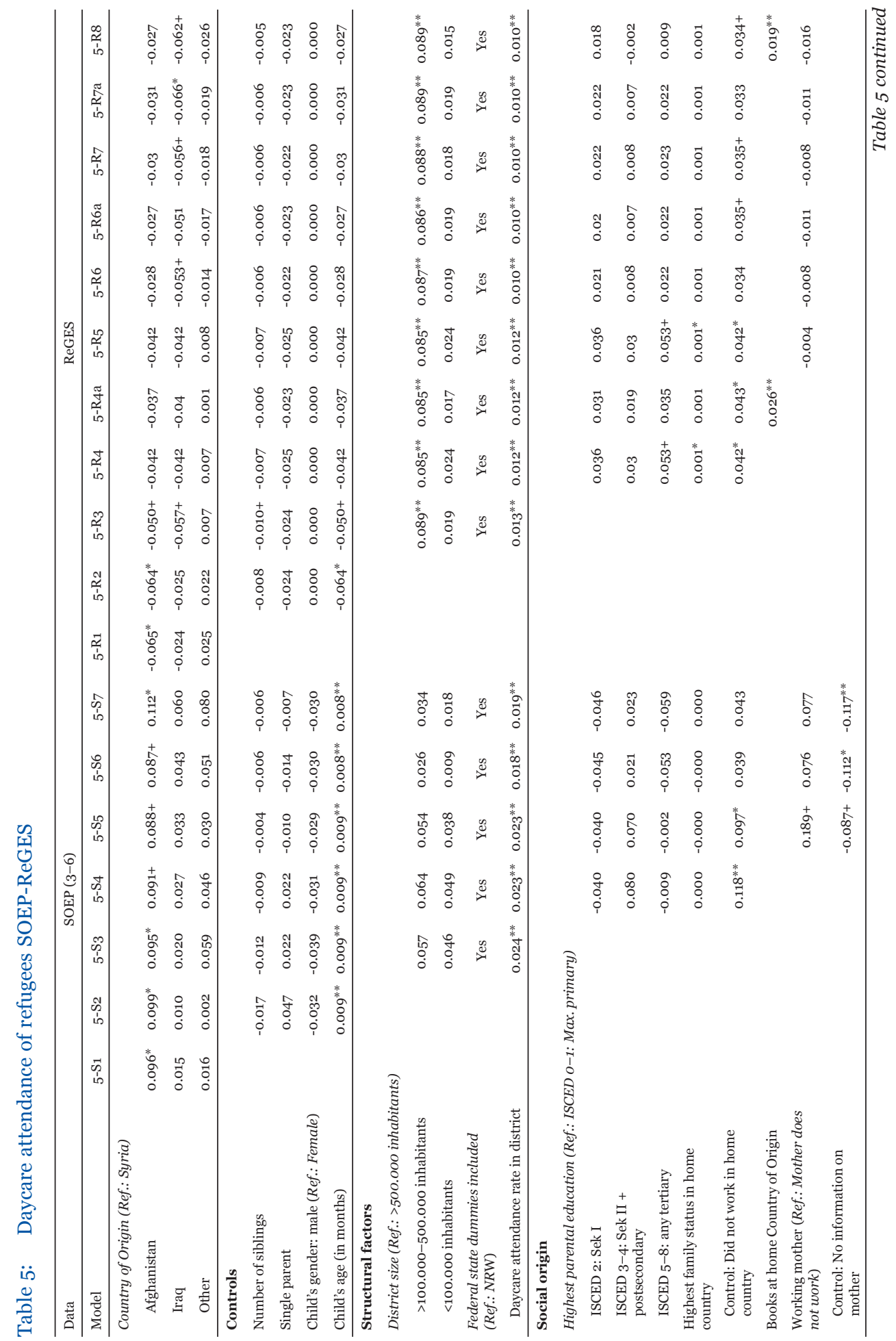


| Christoph Homuth, Elisabeth Liebau \& Gisela Will

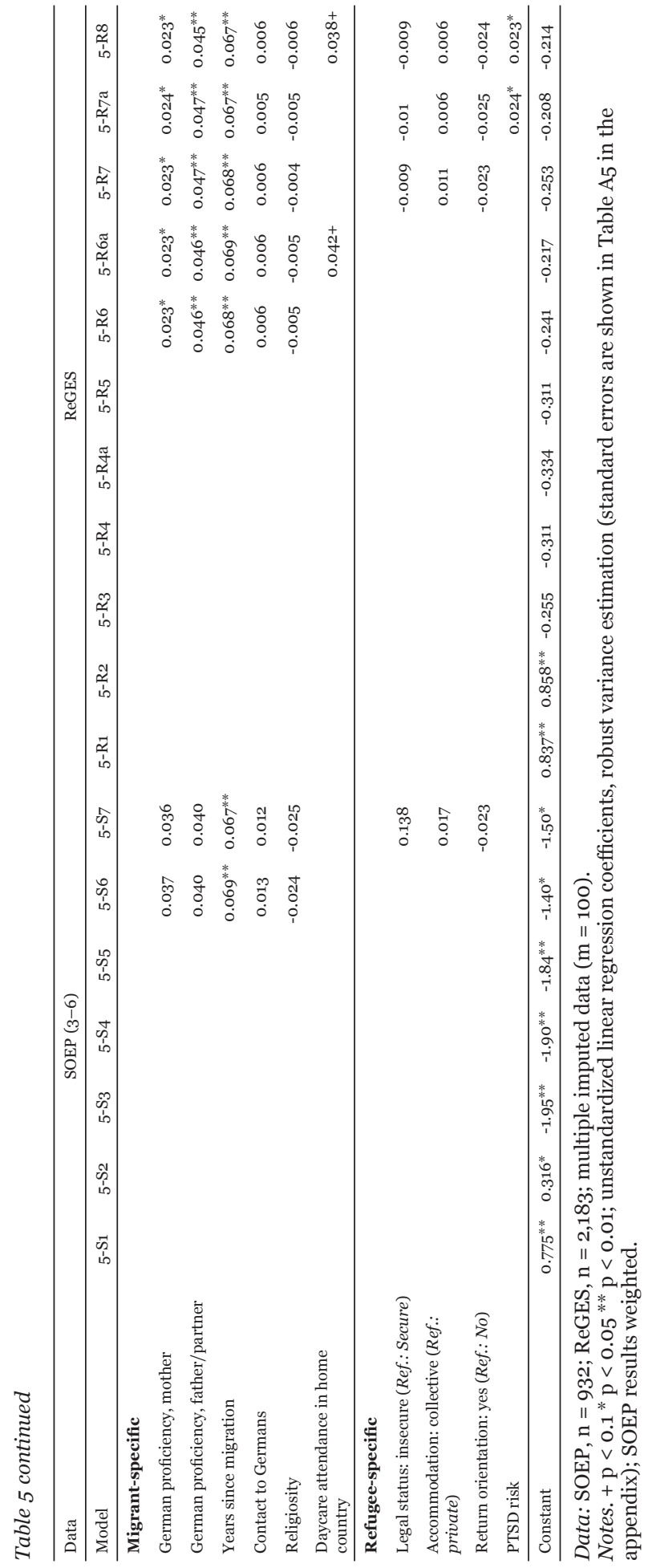

42 JERO, Vol. 13, No. 1 (2021) 


\section{Summary and discussion}

This article aimed to shed further light on the structural integration of refugee children into the German educational system by comparing refugee children's daycare attendance with that of other children in Germany. Furthermore, we used two unique data sets to analyze differences in the daycare attendance of refugee children of different ages for the first time.

The first important result is that refugee children do attend daycare centers, even though their daycare attendance rates are still lower than those of non-migrant children and children from other types of migrant families. The second important result is that these inequalities can be explained by socioeconomic, cultural, and structural factors known from the literature. Lastly, we showed that refugee-specific factors do not have an important impact on daycare attendance.

For the o-to-3-years age group, the differences in the attendance rates of refugees can be explained mainly by socioeconomic indicators. In particular, their mothers' labor market participation increases children's probability of attending a daycare center. At a policy level, our findings indicate the importance of rapid labor market integration of refugee families. Especially for the age group of under3-year-olds, labor market integration can be seen as the key factor for daycare attendance. Differences between refugees and other migrants can be explained by structural factors, while migrant- and refugee-specific factors play only a minor role in explaining differences between refugees and other migrants as well as between refugee groups.

For the age group of 3-to-6-year-old children, socioeconomic factors are central for the explanation of differences in daycare attendance among the three observed groups. Mothers' employment again shows the strongest association. In contrast to the younger age group, structural factors and migration-specific factors, years since migration in particular, are important predictors for daycare attendance of refugees and other migrants. Also, we find only minor influences of refugee-specific factors, which is a very important result: neither refugees' legal status nor their type of accommodation has a significant influence on their participation in preschool education.

For future research, it is important to take a closer look at the factors which influence how long it takes refugee children to enroll in a daycare center. Statements from daycare directors suggest that the support of specialist staff and volunteers plays a major role here (see Baisch et al., 2017). Besides, however, we found a great influence of structural factors that is more prominent for refugee children than for this age group in general. Especially in districts with an ample supply of daycare places, the probability of enrolling in a daycare center was significantly higher. This indicates that it is especially important for refugees to have access to a sufficient supply of daycare places.

There are, however, some limitations to our current findings. First, refugees who have not yet been assigned to a host community are not included in the ReGES sample and probably are less likely to have been included in the SOEP sur- 
vey; the results should therefore not be hastily generalized to refugees who still live in initial reception facilities or AnKER centers. Second, at this point, our study design is cross-sectional, which precludes certain insights (e.g., on the causal relationship between parents' German language proficiency and daycare attendance). In further studies, it will be possible to use longitudinal data from both the SOEP and the ReGES study to address some of these current limitations.

Lastly, the question of whether refugee status should be regarded as a separate dimension of inequality remains not satisfactorily answered yet. For refugees who live in Germany for some time and who are allocated to municipalities, the same social mechanisms explain most of the educational differences between them, other migrants, and non-migrants in early and preschool age. To explain the remaining differences between these groups and within the refugee population, it is necessary to integrate refugee-specific conditions into our theoretical models. This may be especially important for special refugee groups like those in AnKER centers.

\section{Acknowledgments}

The ReGES project on which this article is partly based is funded by the German Federal Ministry of Education and Research under grant number FLUCHTo3. The content of this publication is solely the responsibility of the authors.

\section{References}

Aktionsrat Bildung (2016). Integration durch Bildung. Migranten und Flüchtlinge in Deutschland. Münster: Waxmann.

Alt, C., Berngruber, A., \& Pötter, U. (2016). Wer bemüht sich um einen Kitaplatz und wer nimmt ihn in Anspruch? Ein Vergleich zwischen Migranten- und autochthonen Familien mit Kindern unter drei Jahren. Zeitschrift für Pädagogik 62 (2016) $5,690-706$

Baisch, B., Lüders, K., Meiner-Teubner, C., Riedel, B., \& Scholz, A. (2017). Flüchtlingskinder in Kindertagesbetreuung. Ergebnisse der DJI-Kita-Befragung „Flüchtlingskinder" zu Rahmenbedingungen und Praxis im Frühjahr 2016. München: Deutsches Jugendinstitut e. V. (DJI)

BAMF - Bundesamt für Migration und Flüchtlinge. (2016). Das Bundesamt in Zahlen 2015. Asyl, Migration und Integration. Nürnberg: BAMF.

BAMF - Bundesamt für Migration und Flüchtlinge. (2017). Das Bundesamt in Zahlen 2016. Asyl, Migration und Integration. Nürnberg: BAMF.

BAMF - Bundesamt für Migration und Flüchtlinge. (2018). Das Bundesamt in Zahlen 2017. Asyl, Migration und Integration. Nürnberg: BAMF.

Becker, B. (2010). Wer profitiert mehr vom Kindergarten? Die Wirkung der Kindergartenbesuchsdauer und Ausstattungsqualität auf die Entwicklung des deutschen Wortschatzes bei deutschen und türkischen Kindern. Kölner Zeitschrift für Soziologie und Sozialpsychologie, 62, 139-163. https://doi.org/10.1007/s11577010-0090-5

Becker, B. (2019). Early educational inequality: Growing up in different learning environments. In R. Becker (Ed.), Research Handbook on the Sociology of Education (pp. 233-252). Cheltenham: Edward Elgar Publishing. https://doi. org/10.4337/9781788110426.00023 
Becker, B., \& Biedinger, N. (2006). Ethnische Bildungsungleichheit zu Schulbeginn. Kölner Zeitschrift für Soziologie und Sozialpsychologie, 58(4), 660-684. https:// doi.org/10.1007/s11577-006-0261-6

Becker, B., \& Biedinger, N. (2016). Ethnische Ungleichheiten in der vorschulischen Bildung. In C. Diehl, C. Hunkler, \& C. Kristen (Eds.), Ethnische Ungleichheiten im Bildungsverlauf: Mechanismen, Befunde, Debatten (pp. 433-474). Wiesbaden: Springer VS. https://doi.org/10.1007/978-3-658-04322-3_10

Becker, B., \& Schmidt, F. (2013). Ungleiche Startvoraussetzungen zu Beginn der Schullaufbahn? Unterschiede in den mathematischen und sprachlichen Fähigkeiten von sechsjährigen Kindern nach Geschlecht und Migrationshintergrund. In A. Hadjar \& S. Hupka-Brunner (Eds.), Geschlecht, Migrationshintergrund und Bildungserfolg (pp. 52-76). Weinheim: Beltz Juventa.

Becker, R., \& Lauterbach, W. (2007). Vom Nutzen vorschulischer Erziehung und Elementarbildung: Bessere Bildungschancen für Arbeiterkinder? In R. Becker \& W. Lauterbach (Eds.), Bildung als Privileg. Erklärungen und Befunde zu den Ursachen der Bildungsungleichheit (pp. 125-255) Wiesbaden: VS Verlag für Sozialwissenschaften. https://doi.org/10.1007/978-3-531-90339-2_5

Becker, R., \& Tremel, P. (2006). Auswirkungen vorschulischer Kinderbetreuung auf die Bildungschancen von Migrantenkindern. Soziale Welt, 57(4), 397-418. https://doi. org/10.5771/0038-6073-2006-4-397

Bertelsmann Stiftung. (2020). Betreuungsquote und Betreuungswunsch 2018. Retrieved from https://www.laendermonitor.de/de/vergleich-bundeslaender-daten/kinderund-eltern/fokus-u3/betreuungsquote-und-betreuungswunsch?tx_itaohyperion_pluginview\%5Baction\%5D=chart\&tx_itaohyperion_pluginview\%5Bcontroller\%5D=PluginView\&cHash=fc1972f3625f7cd8606dod678c35efa4 (27.01.2020).

Boillat, J., \& Chamouton, B. (2013). Protect - Process of Recognition and Orientation of Torture Victims in European Countries to Facilitate Care and Treatment. Retrieved from http://protect-able.eu/wp-content/uploads/2013/o1/protect-global-eng.pdf (31.05.2019).

Breen, R., \& Goldthorpe, J. H. (1997). Explaining educational differentials. Towards a formal rational action theory. Rationality and Society 9(3), 275-305. https://doi. org/10.1177/104346397009003002

Burghardt, L. (2017). Zusammenhänge elterlicher Erwartungen und Einstellungen mit der Anmeldung und späteren Inanspruchnahme einer Krippe. Frühe Bildung 6, 83-92. https://doi.org/10.1026/2191-9186/aoo0312

Burghardt, L., \& Kluczniok, K. (2016). Erwartungen von Eltern zu Nutzen und Kosten eines Krippenbesuchs - Eine Analyse zu Zusammenhängen mit kindbezogenen und familialen Strukturmerkmalen. Diskurs Kindheits- und Jugendforschung 11, 339-354. https://doi.org/10.3224/diskurs.v11i3.7

Buuren, S. v. (2018): Flexible imputation of missing data (Second edition). Boca Raton: CRC Press, Taylor \& Francis Group.

Deutsches Institut für Menschenrechte. (2017). Welchen Zugang haben geflüchtete Kinder zu Kitas? Retrieved from http://landkarte-kinderrechte.de/downloads/ Infos-Bundeslaender-Kita-2017.pdf (27.01.2020).

Die Beauftragte der Bundesregierung für Migration, Flüchtlinge und Integration. (2011). Zweiter Integrationsindikatorenbericht. Berlin: ISG / WZB

Dollmann, J. (2010). Türkischstämmige Kinder am ersten Bildungsübergang. Primäre und sekundäre Herkunftseffekte. Wiesbaden: VS Verlag für Sozialwissenschaften. https://doi.org/10.1007/978-3-531-92461-8

El-Mafaalani, A., \& Massumi, M. (2019). Flucht und Bildung: frühkindliche, schulische, berufliche und non-formale Bildung. (State-of-Research Papier o8a, Verbundprojekt, Flucht: Forschung und Transfer). Osnabrück: Institut für Migrationsforschung und Interkulturelle Studien (IMIS) der Universität Osnabrück/ Bonn: Internationales Konversionszentrum Bonn (BICC). 
Fuchs-Rechlin, K. (2008). Kindertagesbetreuung im Spiegel des Sozioökonomischen Panels. In Zahlenspiegel 2007. In Forschungsverbund Deutsches Jugendinstitut und Universität Dortmund (Ed.), Kindertagesbetreuung im Spiegel der Statistik (pp. 203-217). München: Deutsches Jugendinstitut.

Fuchs-Rechlin, K., \& Bergmann, C. (2014). Der Abbau von Bildungsbenachteiligung durch Kindertagesbetreuung für unter 3-Jährige - zwischen Wunsch und Wirklichkeit. Sonderheft 24 der Zeitschrift für Erziehungswissenschaft, 95-118. https://doi.org/10.1007/s11618-013-0464-3

Gambaro, L., Liebau, E., Peter, F., \& Weinhardt, F. (2017). Viele Kinder von Geflüchteten besuchen eine Kita oder Grundschule - Nachholbedarf bei den unter Dreijährigen und der Sprachförderung von Schulkindern. DIW Wochenbericht 19/2017, 379-386.

Gambaro, L., Neidhöfer, G., \& Spieß, C. K. (2019). Kita-Besuch von Kindern aus nach Deutschland geflüchteten Familien verbessert Integration ihrer Mütter. $D I W$ Wochenbericht Nr. 44/2019, 806-812.

Geier, B., \& Riedel, B. (2008). Ungleichheiten der Inanspruchnahme öffentlicher frühpädagogischer Angebote. Einflussfaktoren und Restriktionen elterlicher Betreuungsentscheidungen. Zeitschrift für Erziehungswissenschaft 10, 11-28. https://doi.org/10.1007/978-3-531-91452-7_2

Goebel, J., Grabka, M. M., Liebig, S., Kroh, M., Richter, D., Schröder, C., \& Schupp, J. (2019). The German Socio-Economic Panel Study (SOEP). Jahrbücher für Nationalökonomie und Statistik 239(2), 345-360. doi: https://doi.org/10.1515/ jbnst-2018-0022

Gresch, C. (2012). Der Übergang in die Sekundarstufe I. Leistungsbeurteilung, Bildungsaspiration und rechtlicher Kontext bei Kindern mit Migrationshintergrund. Wiesbaden: Springer VS. https://doi.org/10.1007/978-3-531-18660-3

Hank, K., Tillmann, K., \& Wagner, G. (2001). Außerhäusliche Kinderbetreuung in Ostdeutschland vor und nach der Wiedervereinigung. Ein Vergleich mit Westdeutschland in den Jahren 1990-1999. (MPIDR Working Paper WP 2001o03). Rostock: Max Planck Institute for Demographic Research. https://doi. org/10.4054/MPIDR-WP-2001-003

Heckmann, J. J., \& Lochner, L. (2000). Rethinking Education and Training Policy. Understanding the Sources of Skill Formation in a Modern Economy. In S. Danzinger \& J. Waldfogel (Eds.), Securing the Future. Investing in Children from Birth to College (pp. 47-83). New York: Russell Sage.

Hunkler, C., \& Khourshed, M. (n.d.). The Role of Trauma for Integration: the Case of Syrian Refugees. Soziale Welt.

Kreyenfeld, M., \& Krapf, S. (2010). Soziale Ungleichheit und Kinderbetreuung Eine Analyse der sozialen und ökonomischen Determinanten der Nutzung von Kindertages-einrichtungen. In R. Becker \& W. Lauterbach (Eds.), Bildung als Privileg? Erklärungen und Befunde zu den Ursachen der Bildungsungleichheit, 4th edition (pp. 107-128). Wiesbaden: VS Verlag für Sozialwissenschaften. https:// doi.org/10.1007/978-3-531-92484-7_4

Kühne, S., Jacobsen, J., \& Kroh, M. (2019). Sampling in Times of High Migration: The Survey Process of the IAB-BAMF-SOEP Survey of Refugees. Survey Methods: Insights from the Field. Retrieved from https://surveyinsights.org/?p=11416.

Lee, R. H., Han, W.-J., Waldfogel, J., \& Brooks-Gunn, J. (2018). Preschool attendance and school readiness for children of immigrant mothers in the United States. Journal of Early Childhood Research, 16(2), 190-209. https://doi. org/10.1177/1476718X18761218

Lehrl, S., Kuger, S., \& Anders, Y. (2014). Soziale Disparitäten beim Zugang zu Kindergartenqualität und differenzielle Konsequenzen für die vorschulische mathematische Entwicklung. Unterrichtswissenschaft, 42(2), 132-151. 
Peter, F., \& Spieß, C. K. (2015). Kinder mit Migrationshintergrund in Kindertageseinrichtungen und Horten: Unterschiede zwischen den Gruppen nicht vernachlässigen! DIW Wochenbericht 82(1-2), 12-21.

Relikowski, I., Schneider, T., \& Linberg, T. (2015). Rezeptive Wortschatz- und Grammatikkompetenzen von Fünfjährigen mit und ohne Migrationshintergrund: Eine empirische Untersuchung aus bildungssoziologischer Perspektive. Frühe Bildung, 4(3), 135-143. https://doi.org/10.1026/2191-9186/aooo218

Rubin, D. B. (1987): Multiple Imputation for Nonresponse in Surveys. New York; Chichester; Brisbane; Toronto; Singapore: John Wiley \& Sons.

Sachverständigenrat deutscher Stiftungen für Integration und Migration (2013). Hürdenlauf zur Kita: Warum Eltern mit Migrationshintergrund ihr Kind seltener in die frühkindliche Tagesbetreuung schicken. Retrieved from https://www. stiftung-mercator.de/media/downloads/3_Publikationen/SVR_Huerdenlauf-zurKita_Juni_2013.pdf.

Schild, A., Welker, J., \& Will, G. (in preparation): Language acquisition among refugee children of preschool age.

Schmitz, S., Spieß, C. K., \& Stahl, J. F. (2017). Kindertageseinrichtungen: Ausgaben der Familien sind von 1996 bis 2015 mitunter deutlich gestiegen. DIW Wochenbericht (41), 889-903.

SOEP Group (2019). SOEP-Core v34 - PPATHL: Person-Related Meta-Dataset. SOEP Survey Papers 762: Series D - Variable Descriptions and Coding. Berlin: DIW Berlin/SOEP.

Spieß, K. C., Westermaier, F., \& Marcus, J. (2016). Kinder und Jugendliche mit Fluchthintergrund nutzen freiwillige Bildungsangebote seltener - mit Ausnahme der Schul-AGs. DIW Wochenbericht, 83(55), 765-773.

Statistisches Bundesamt (2019). Betreuungsquote von Kindern unter 6 Jahren mit und ohne Migrationshintergrund. Retrieved from https://www.destatis.de/DE/ Themen/Gesellschaft-Umwelt/Soziales/Kindertagesbetreuung/Tabellen/betreuungsquote-migration-unter6jahren-2018.html (28.01.2020).

Steinhauer, H. W., Zinn, S., \& Will, G. (2019): Sampling refugees for an educational longitudinal survey. Survey Methods: Insights from the Field, Retrieved from https://surveyinsights.org/?p=10741 (21.05.2019).

Stichs, A., \& Rotermund, S. (2017). Vorschulische Kinderbetreuung aus Sicht muslimischer Familien. (Working Paper 78). Nürnberg: Bundesamt für Migration und Flüchtlinge.

Textor, M. R. (2016). Flüchtlingskinder in der Kita. Retrieved from https://www.kindergartenpaedagogik.de/fachartikel/kinder-mit-migrationshintergrund/2386

von Maurice, J., Balaban, E., Will, G., \& Roßbach, H.-G. (2020). Kinder mit Fluchthintergrund: Zur Bedeutung von Kindertageseinrichtungen für einen erfolgreichen Übergang in die Grundschule und den späteren Bildungserfolg. In S. Pohlmann-Rother, S. D. Lange \& U. Franz (Eds.), Kooperation von Kita und Grundschule Band 2: Digitalisierung, Inklusion und Mehrsprachigkeit - Aktuelle Herausforderungen beim Übergang bewältigen (pp. 45-80). Kronach: Carl Link Verlag.

Will, G., Balaban, E., Dröscher, A., Homuth, C., \& Welker, J. (2018a). Integration von Flüchtlingen: Erste Ergebnisse der ReGES-Studie. (LIfBi Working Paper No. 76). Bamberg: Leibniz Institute for Educational Trajectories, National Educational Panel Study.

Will, G., Gentile, R., Henritz, F., \& von Maurice, J. (2018b). ReGES - Refugees in the German Educational System: Forschungsdesign, Stichprobenziehung und Ausschöpfung der ersten Welle. (LIfBi Working Paper No. 75). Bamberg: Leibniz Institute for Educational Trajectories, National Educational Panel Study.

World Bank (2015). Early Childhood Development in Syria. Retrieved from https:// www.worldbank.org/en/country/syria/publication/ecd2015 (29.01.2020). 
| Christoph Homuth, Elisabeth Liebau \& Gisela Will

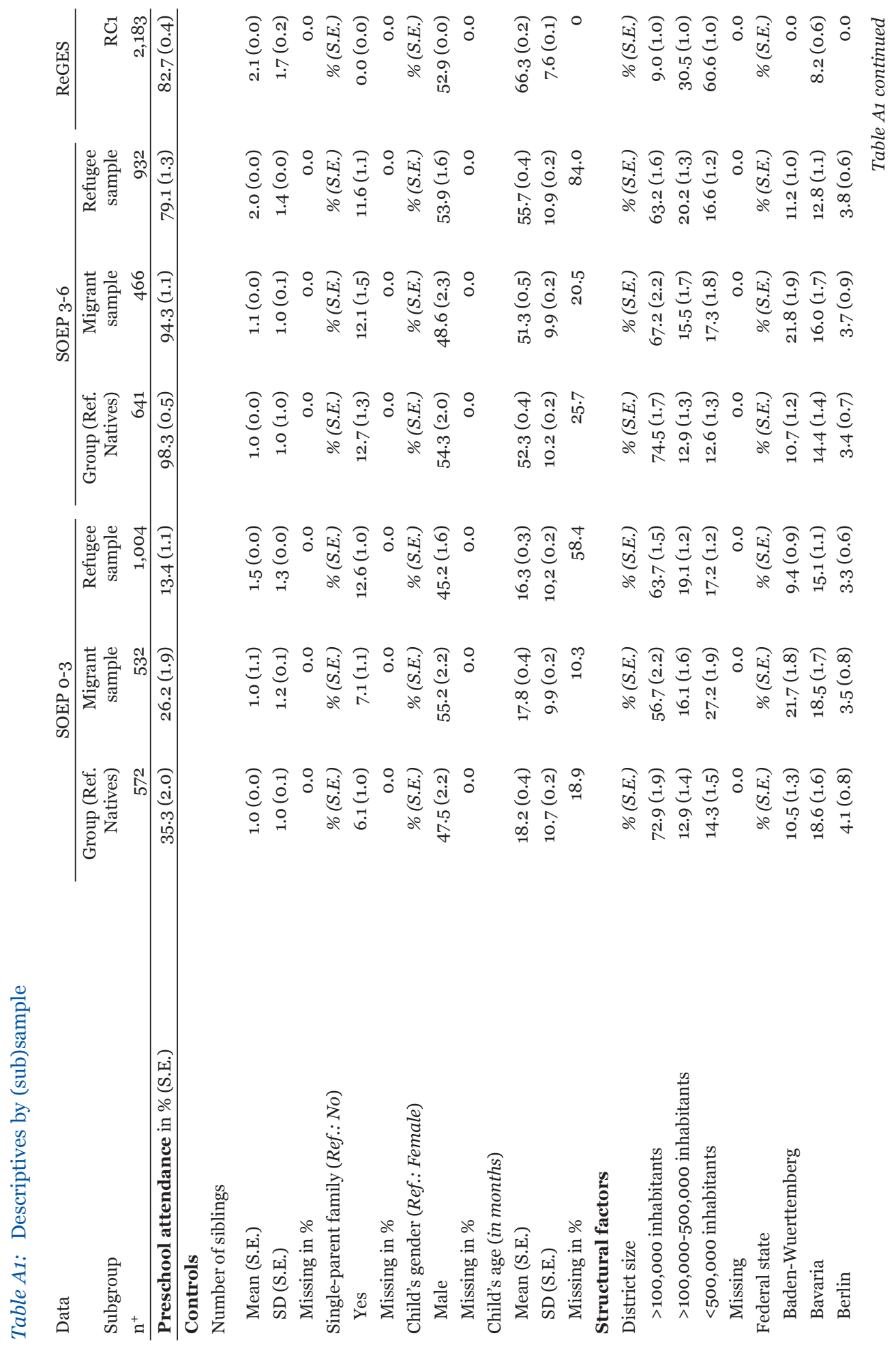


The role of socioeconomic, cultural, and structural factors in daycare attendance |

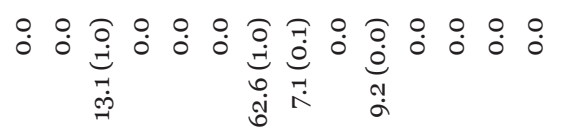

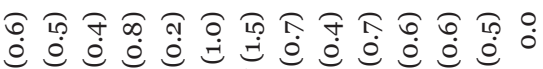

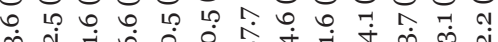

ल 4ं

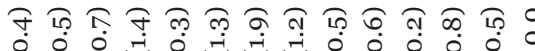

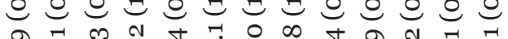

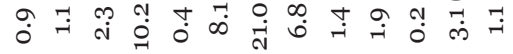

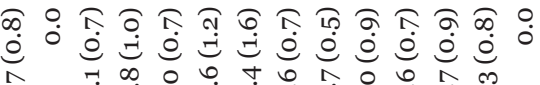

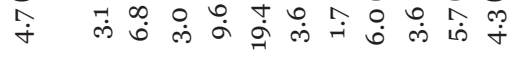

อง เด โิ

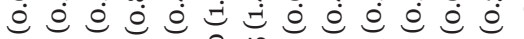

的

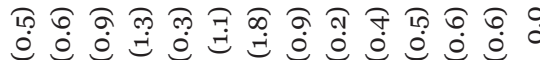

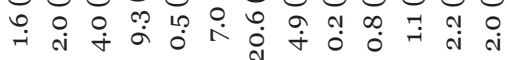

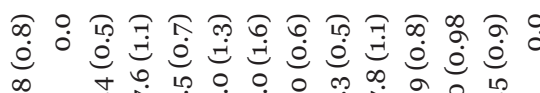

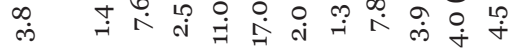

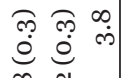

齐

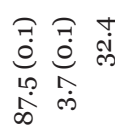

วิ)

$\ddot{\circ} \dot{0}$

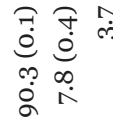

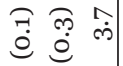

\&ั่

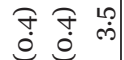

市

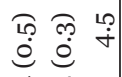

กั่ $\stackrel{\pi}{a} \stackrel{\pi}{a} \frac{\pi}{d} \stackrel{\pi}{a} \frac{\pi}{a}$

官 iิ

चं $\dot{\text { वें }}$

$\infty$ วิก สุ

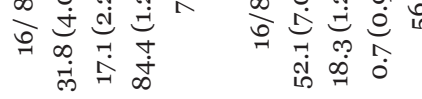

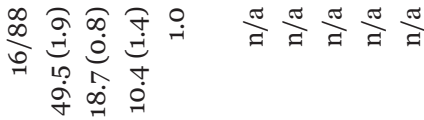

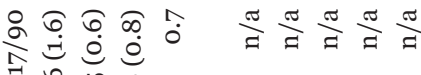

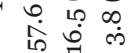

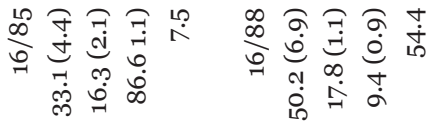

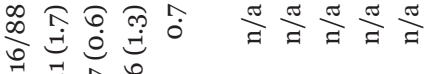
$\begin{array}{ccc}-1 & 0 & 0 \\ 0 & \infty & 0\end{array}$

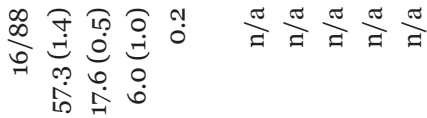

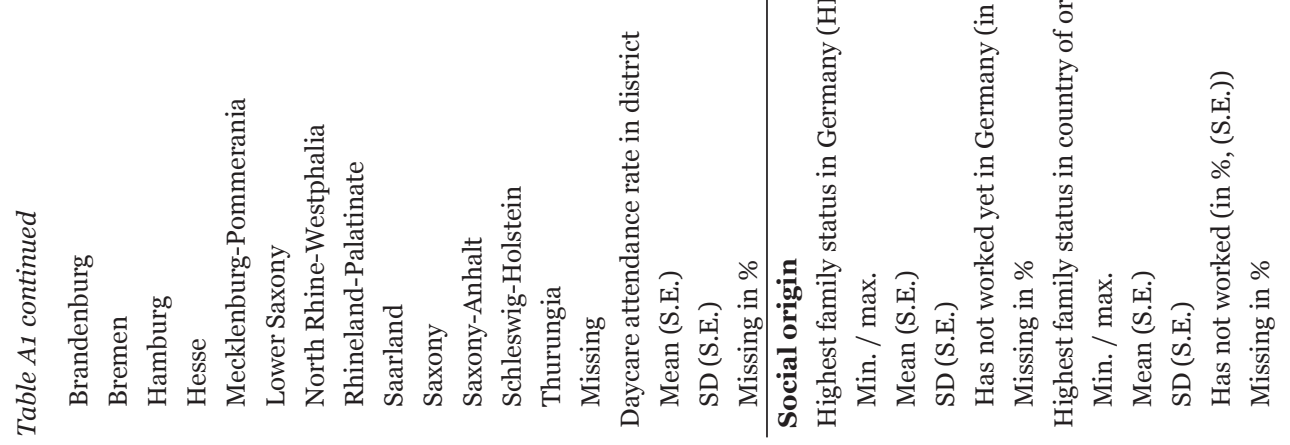


| Christoph Homuth, Elisabeth Liebau \& Gisela Will

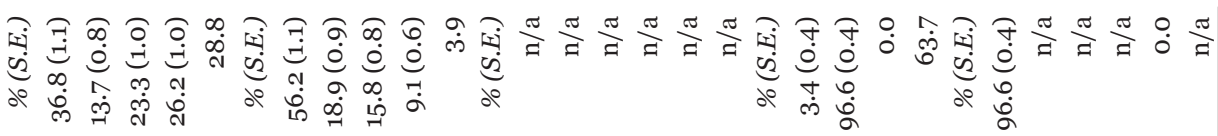

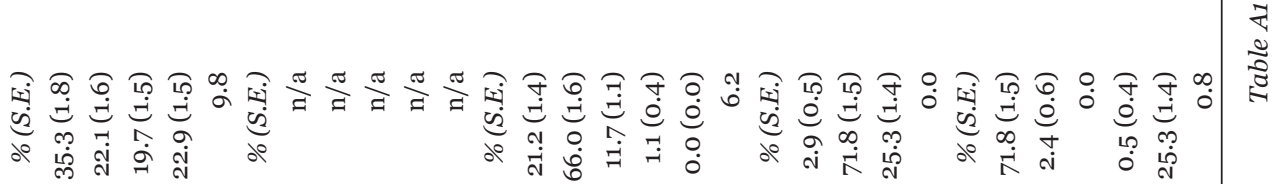

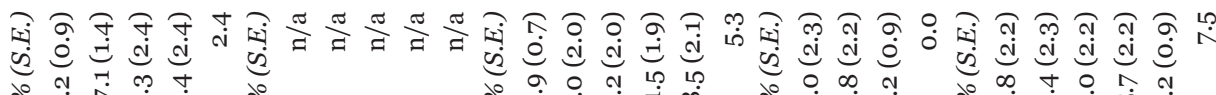

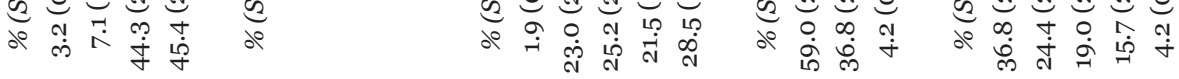

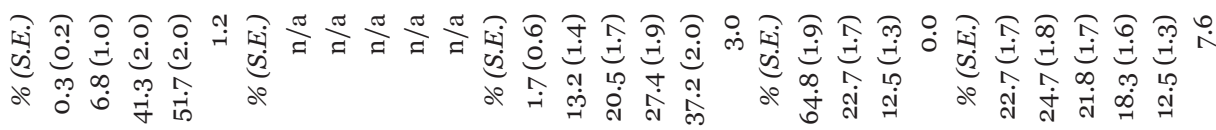

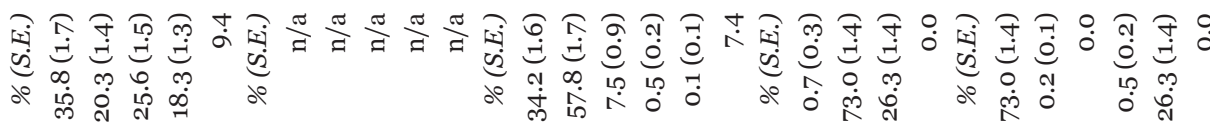

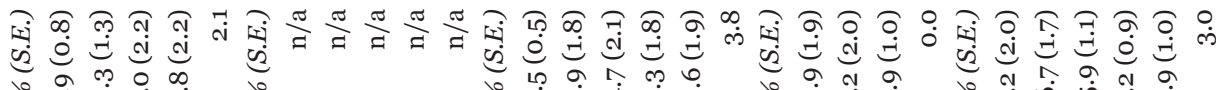

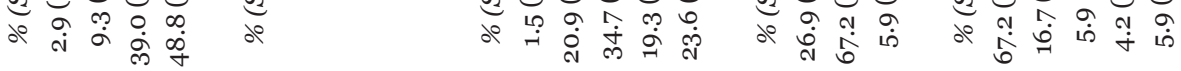

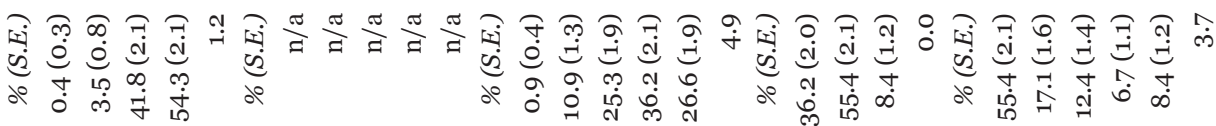

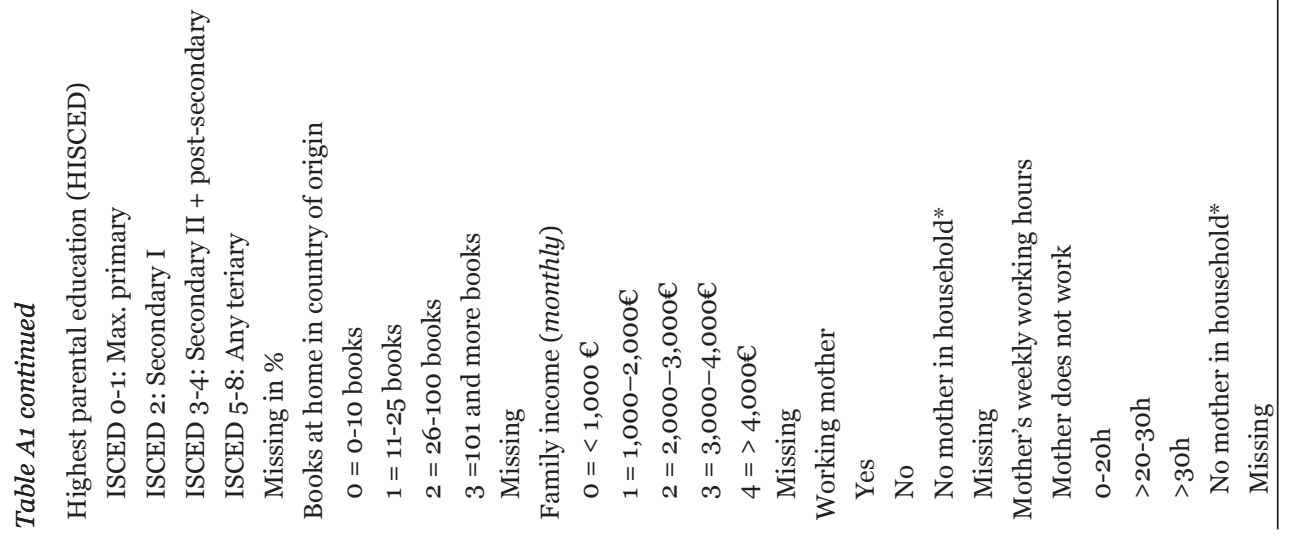


The role of socioeconomic, cultural, and structural factors in daycare attendance |

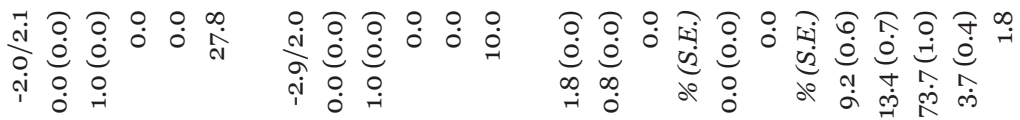

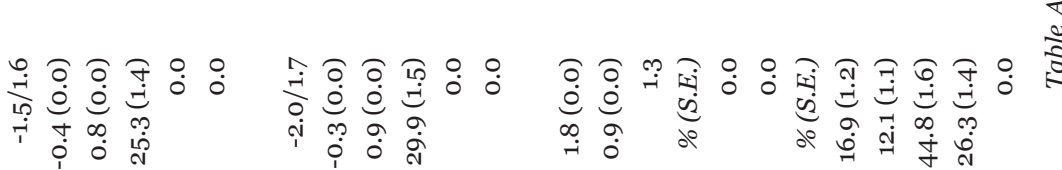

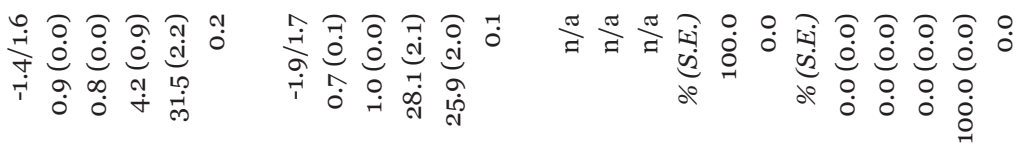

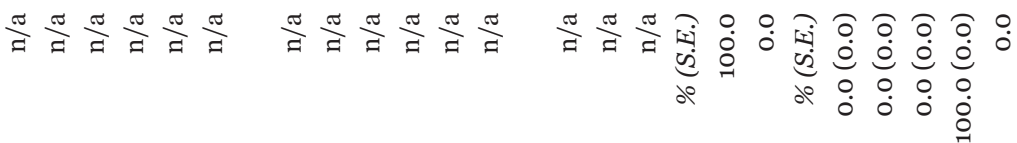

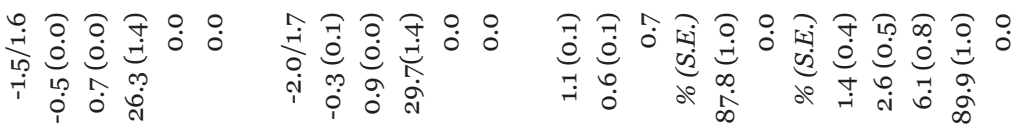

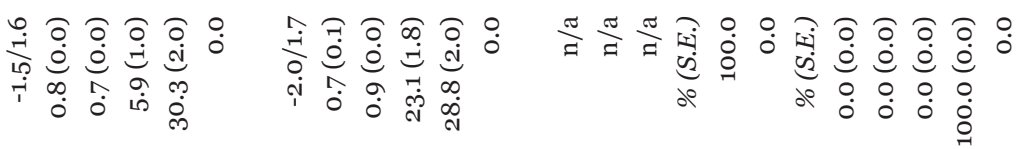

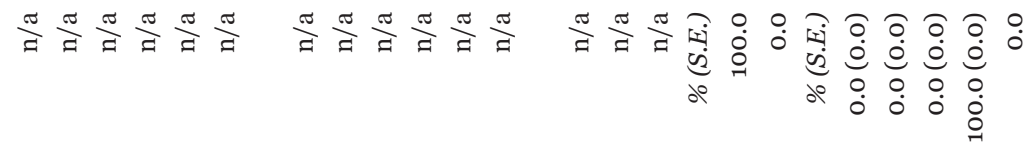

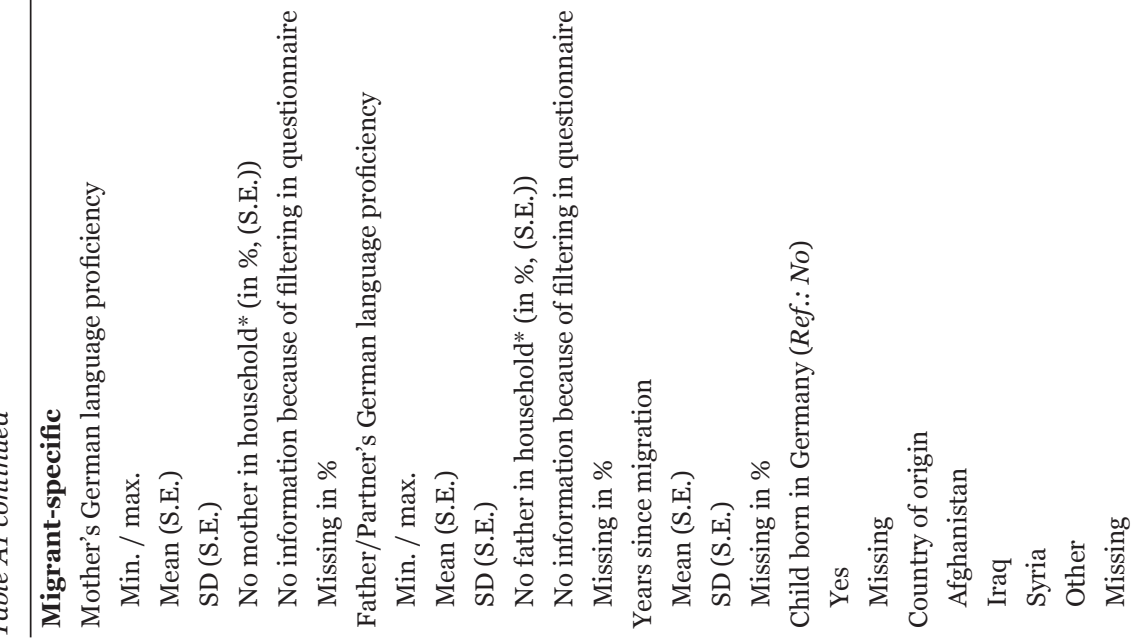


| Christoph Homuth, Elisabeth Liebau \& Gisela Will

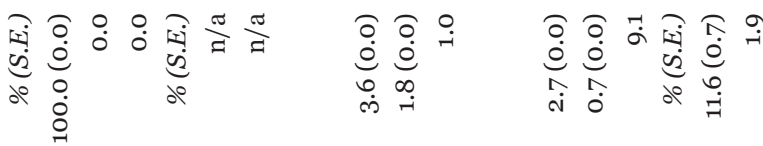

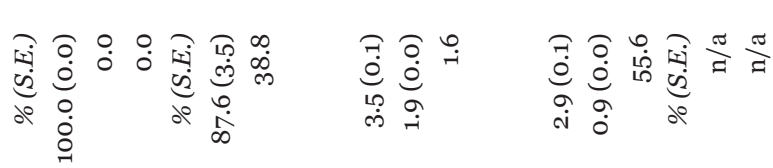

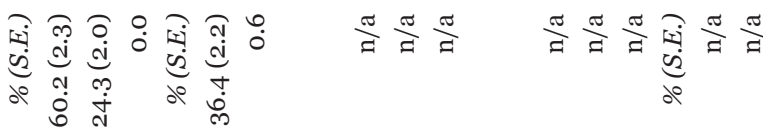

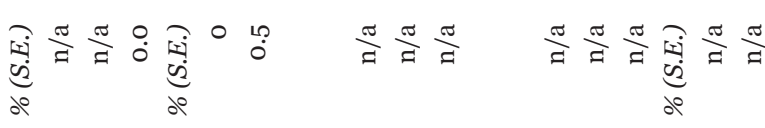

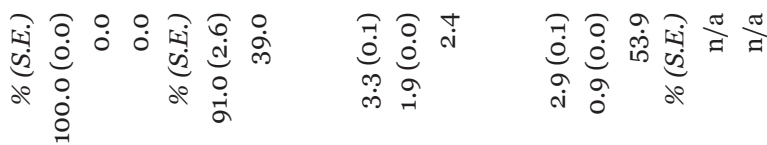

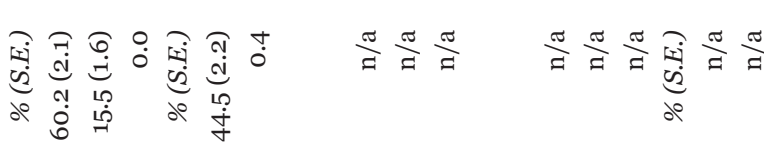

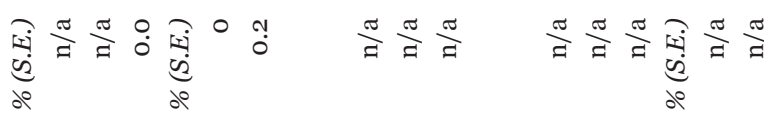

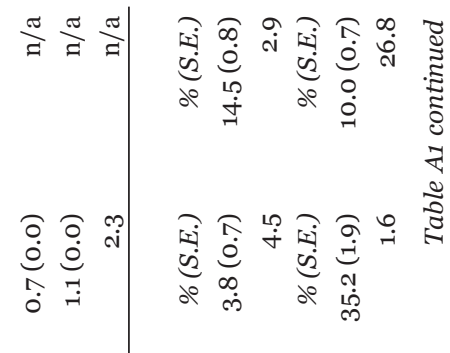

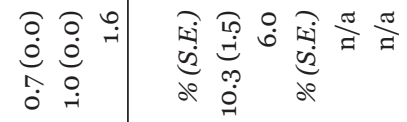

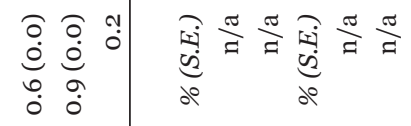

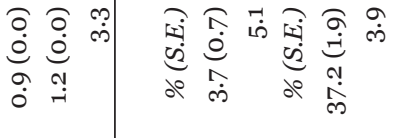

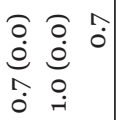

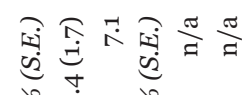

do $\underset{-}{\infty}$ do

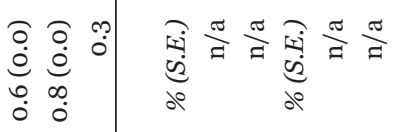

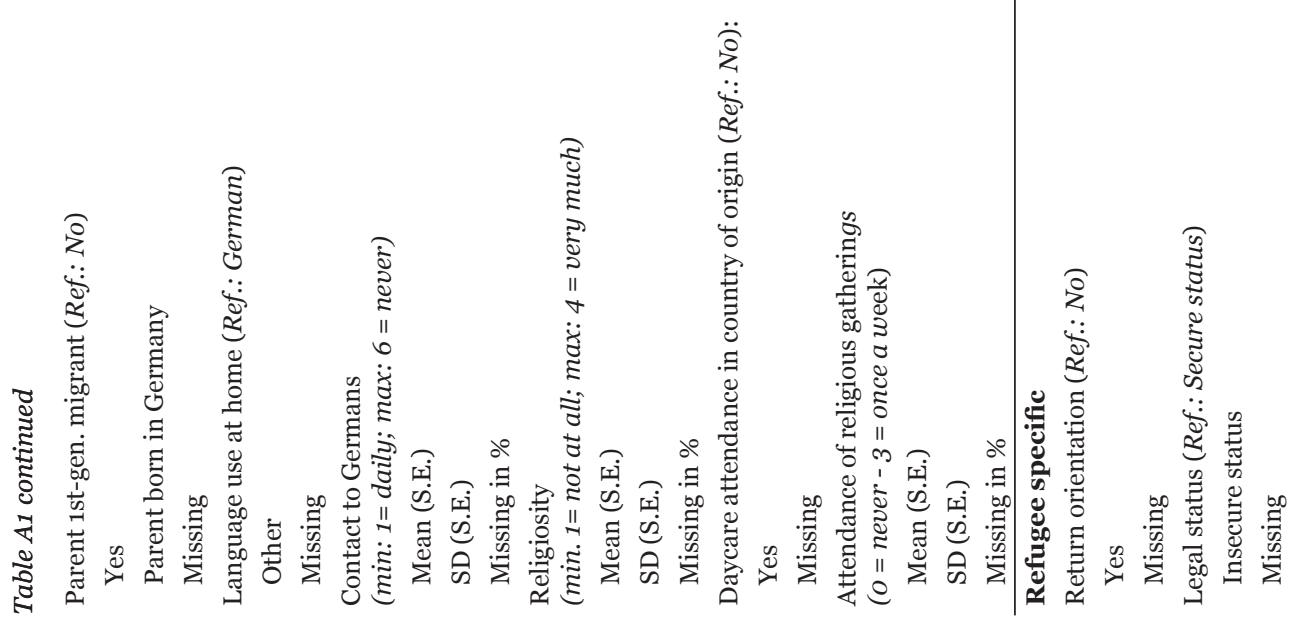


The role of socioeconomic, cultural, and structural factors in daycare attendance |

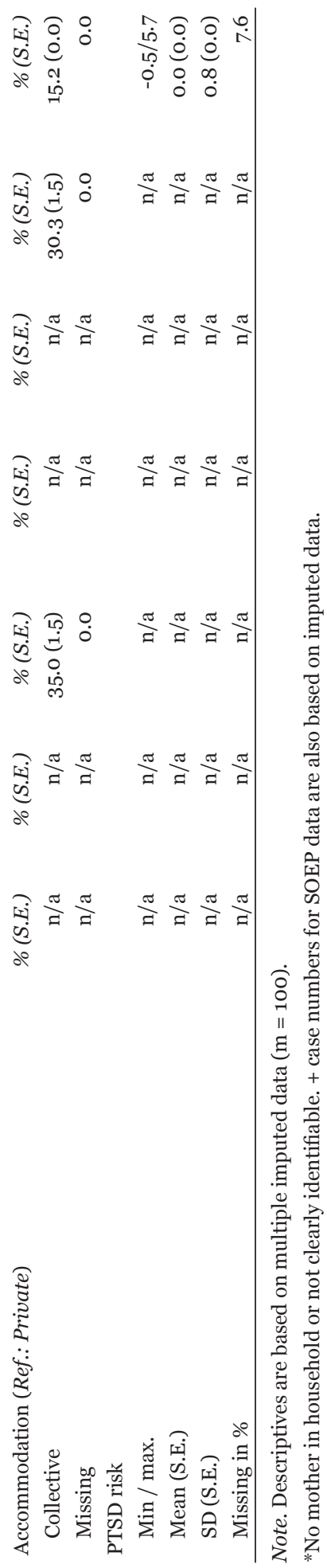




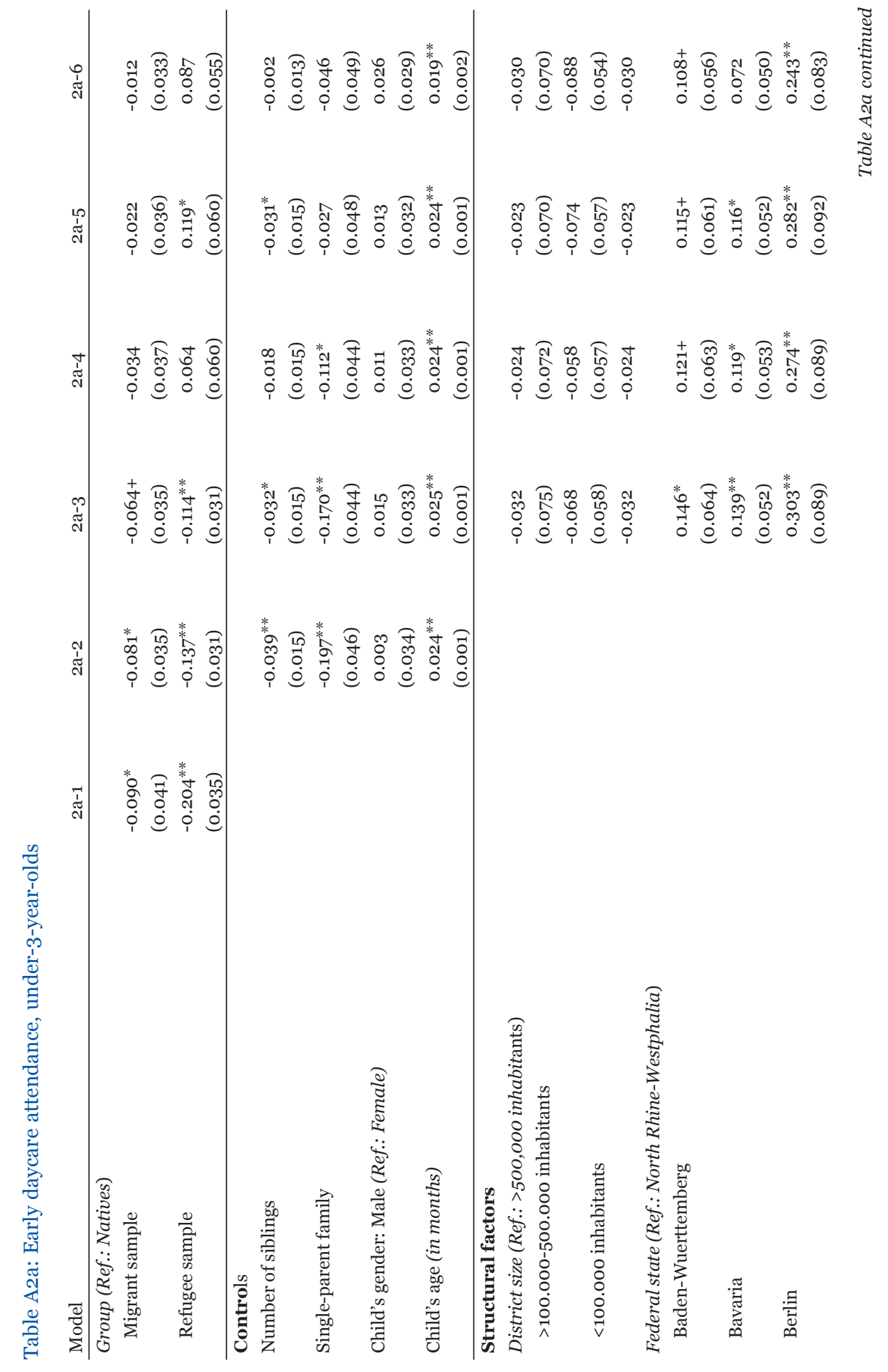

$54 \mid$ JERO, Vol. 13, No. 1 (2021) 
The role of socioeconomic, cultural, and structural factors in daycare attendance |

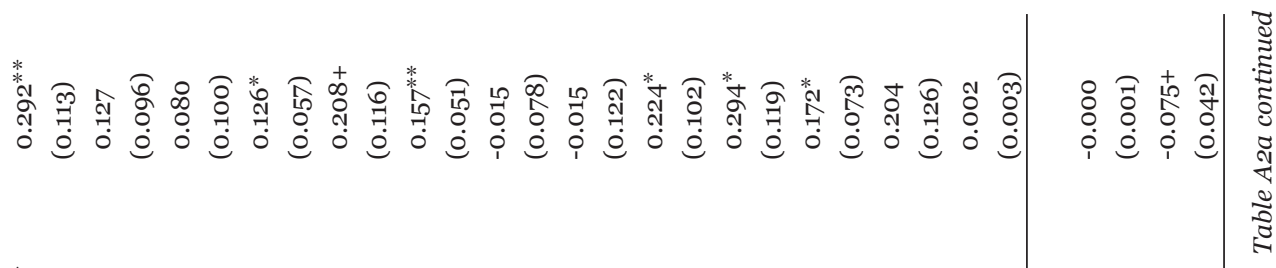

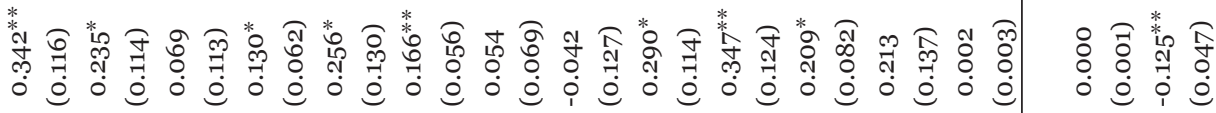

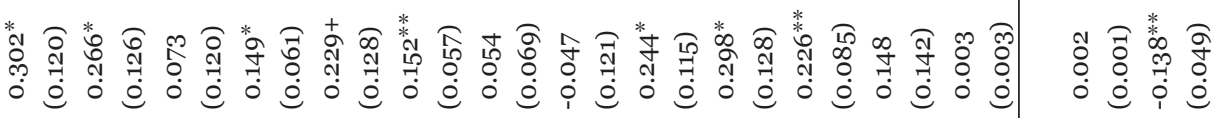

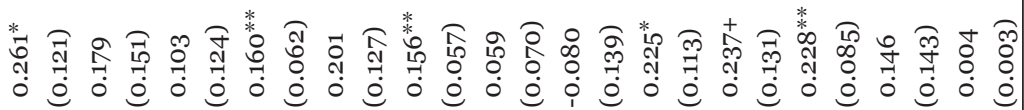

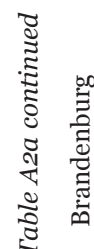

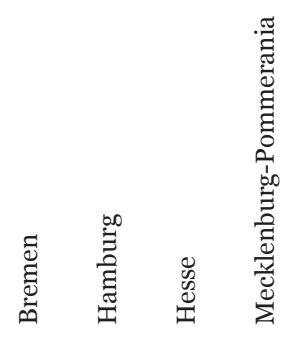

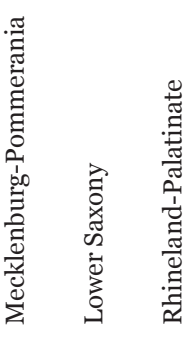

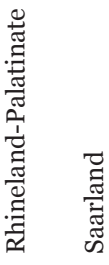

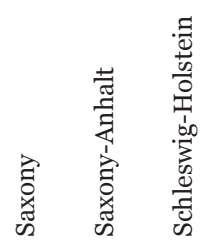

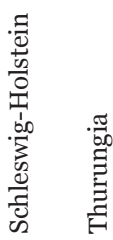

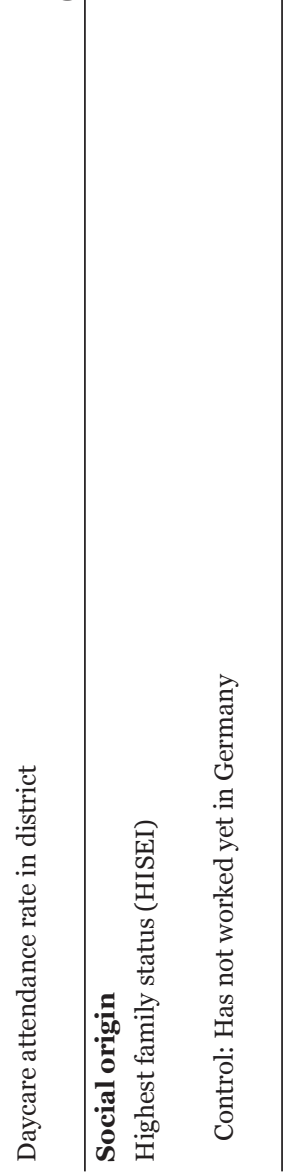

JERO, Vol. 13, No. 1 (2021) 
| Christoph Homuth, Elisabeth Liebau \& Gisela Will

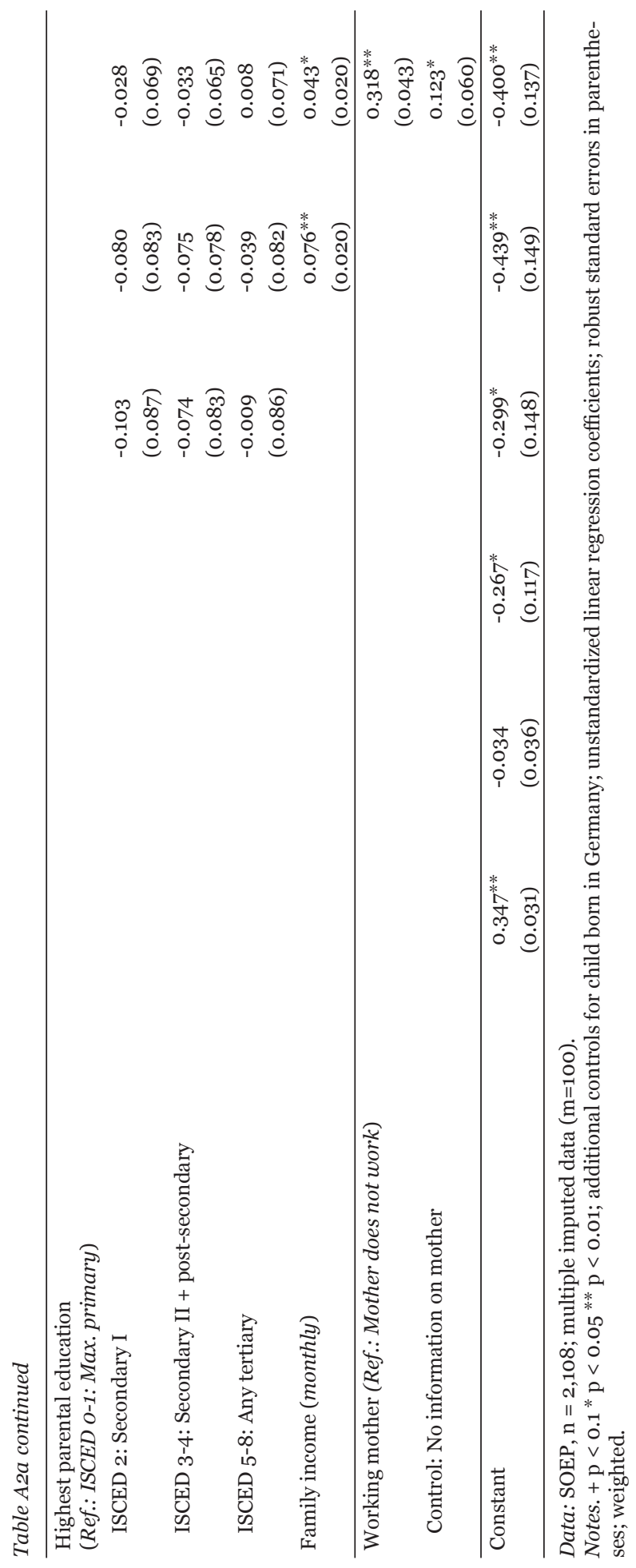

56 | JERO, Vol. 13, No. 1 (2021) 
The role of socioeconomic, cultural, and structural factors in daycare attendance |

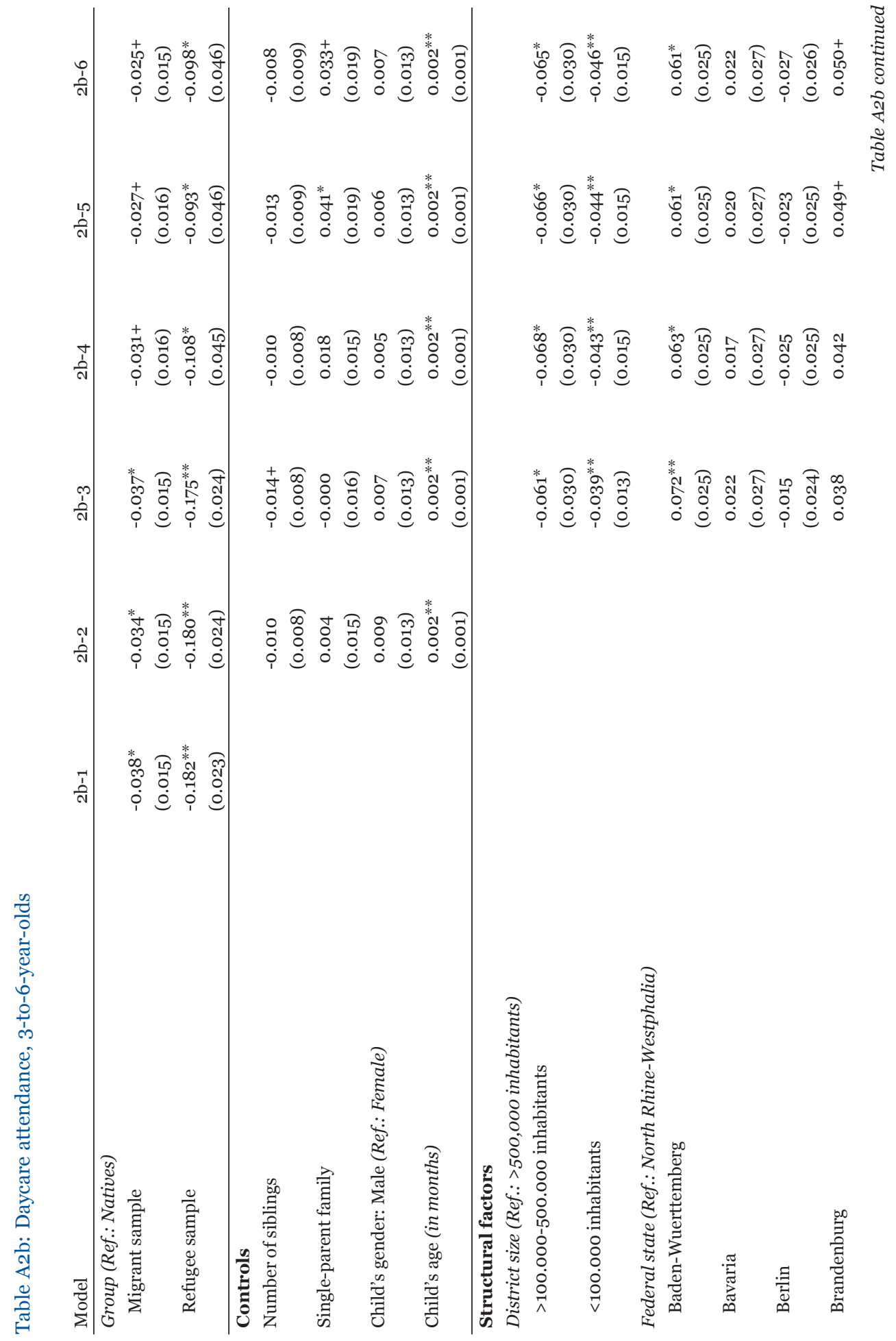


| Christoph Homuth, Elisabeth Liebau \& Gisela Will

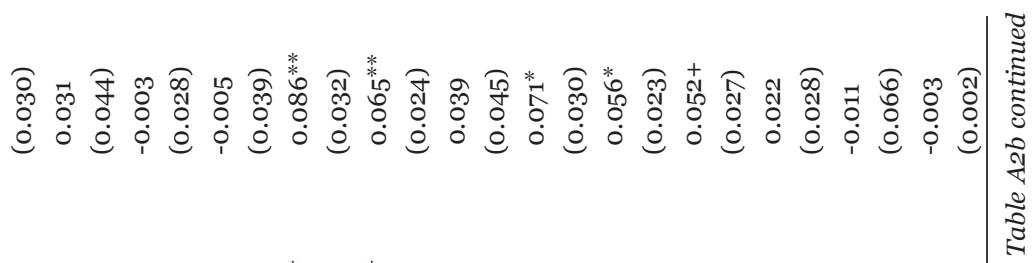

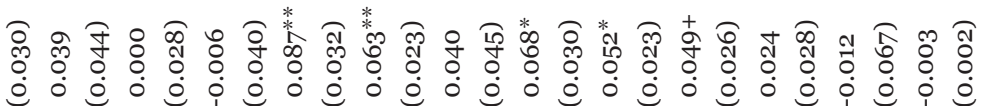

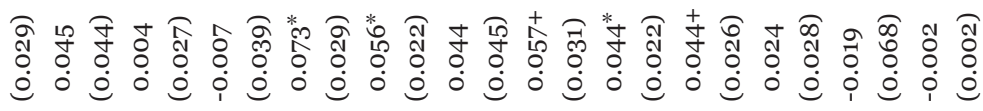

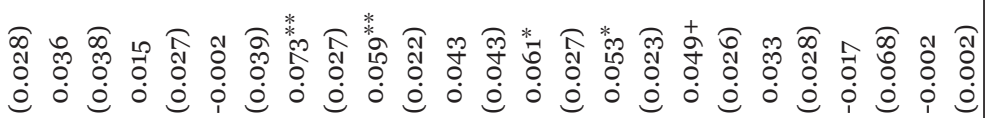

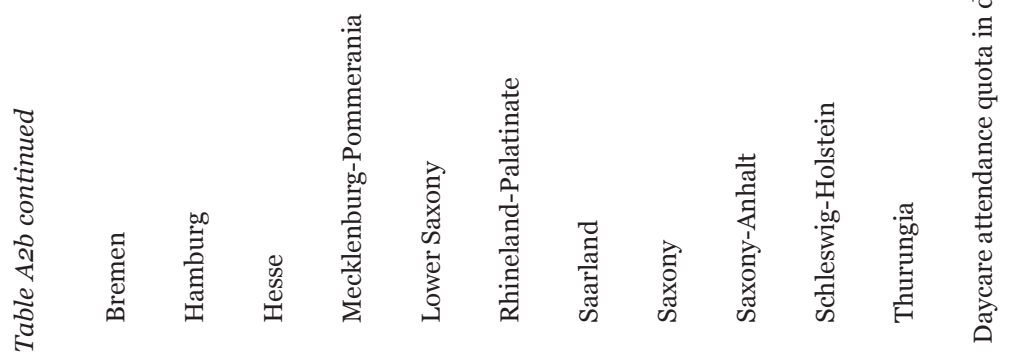

58 | JERO, Vol. 13, No. 1 (2021) 
The role of socioeconomic, cultural, and structural factors in daycare attendance |

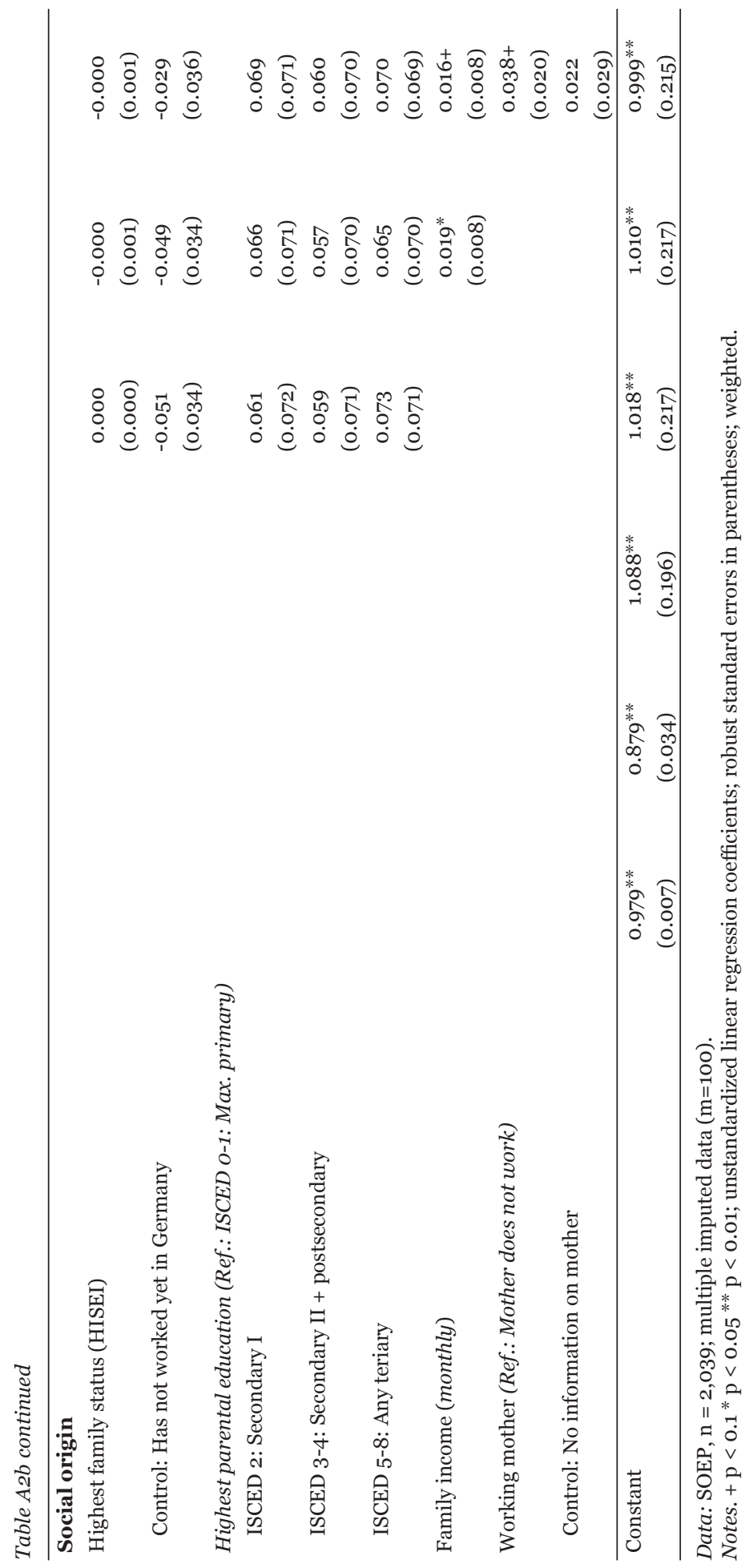




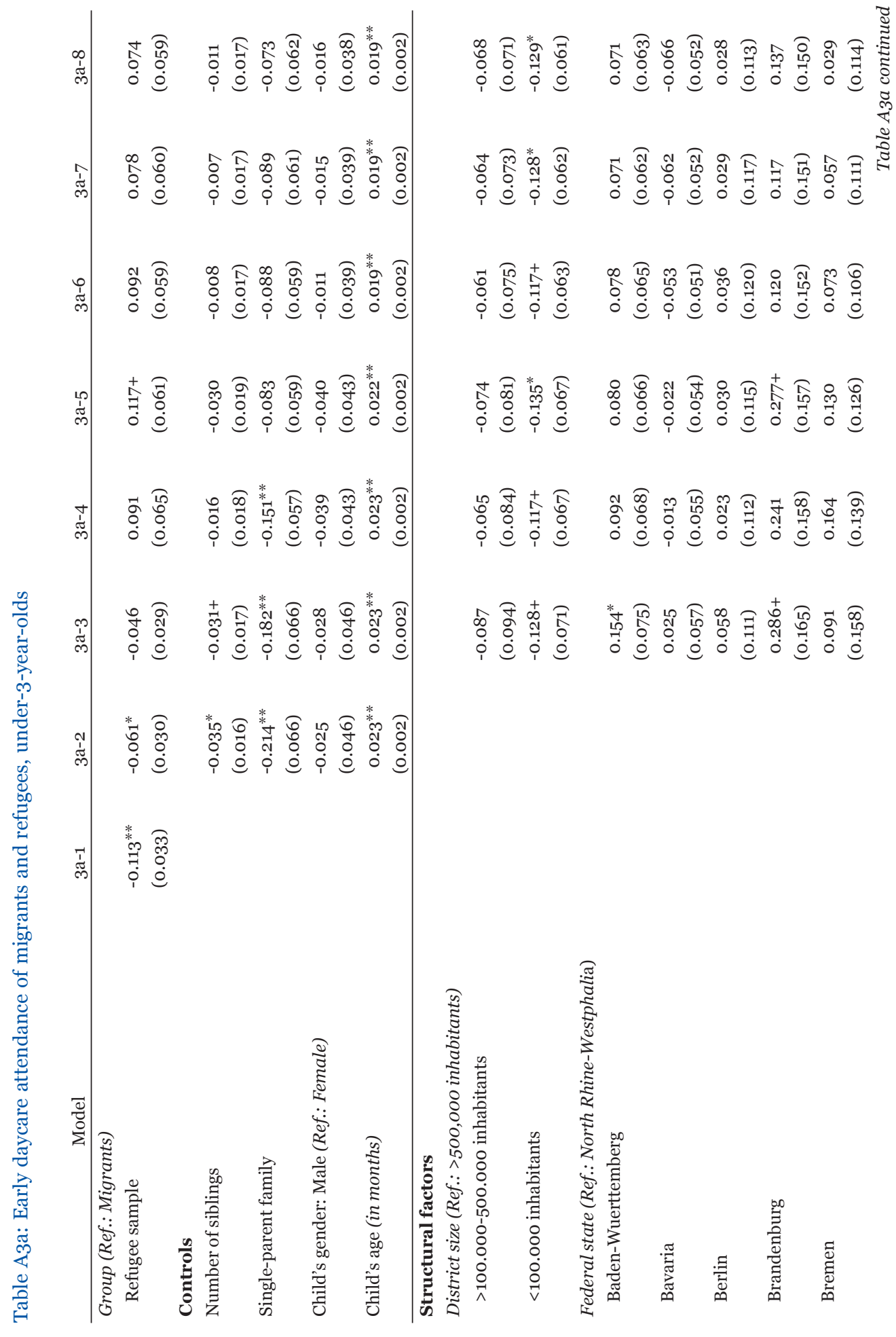

60 | JERO, Vol. 13, No. 1 (2021) 


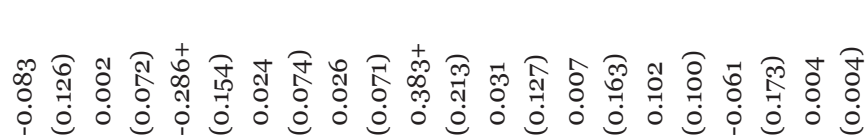

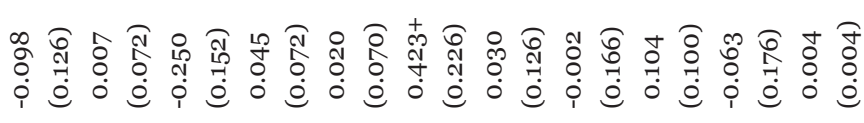

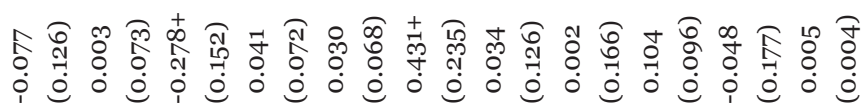

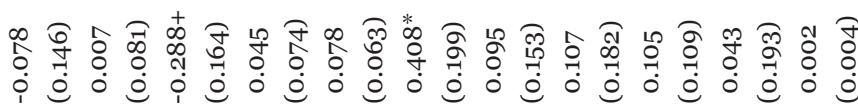

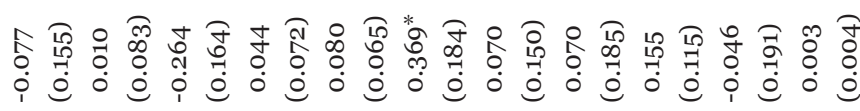

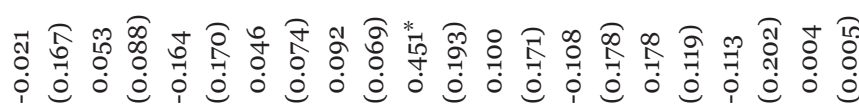

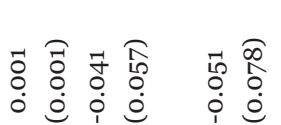

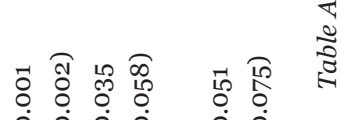

○

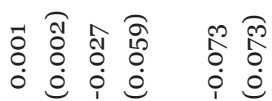

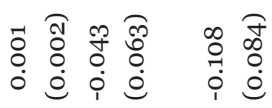

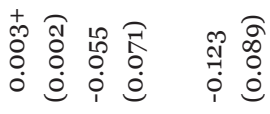

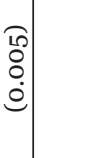


| Christoph Homuth, Elisabeth Liebau \& Gisela Will

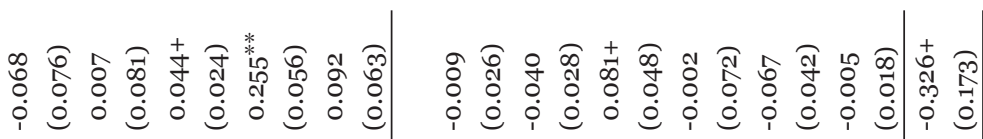

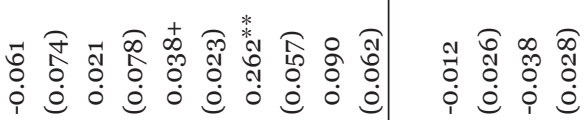

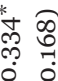

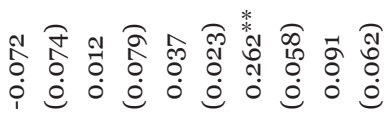

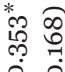

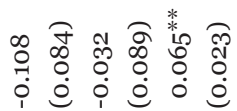

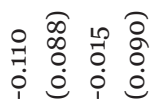

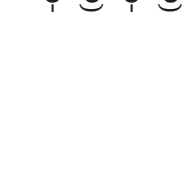


The role of socioeconomic, cultural, and structural factors in daycare attendance |

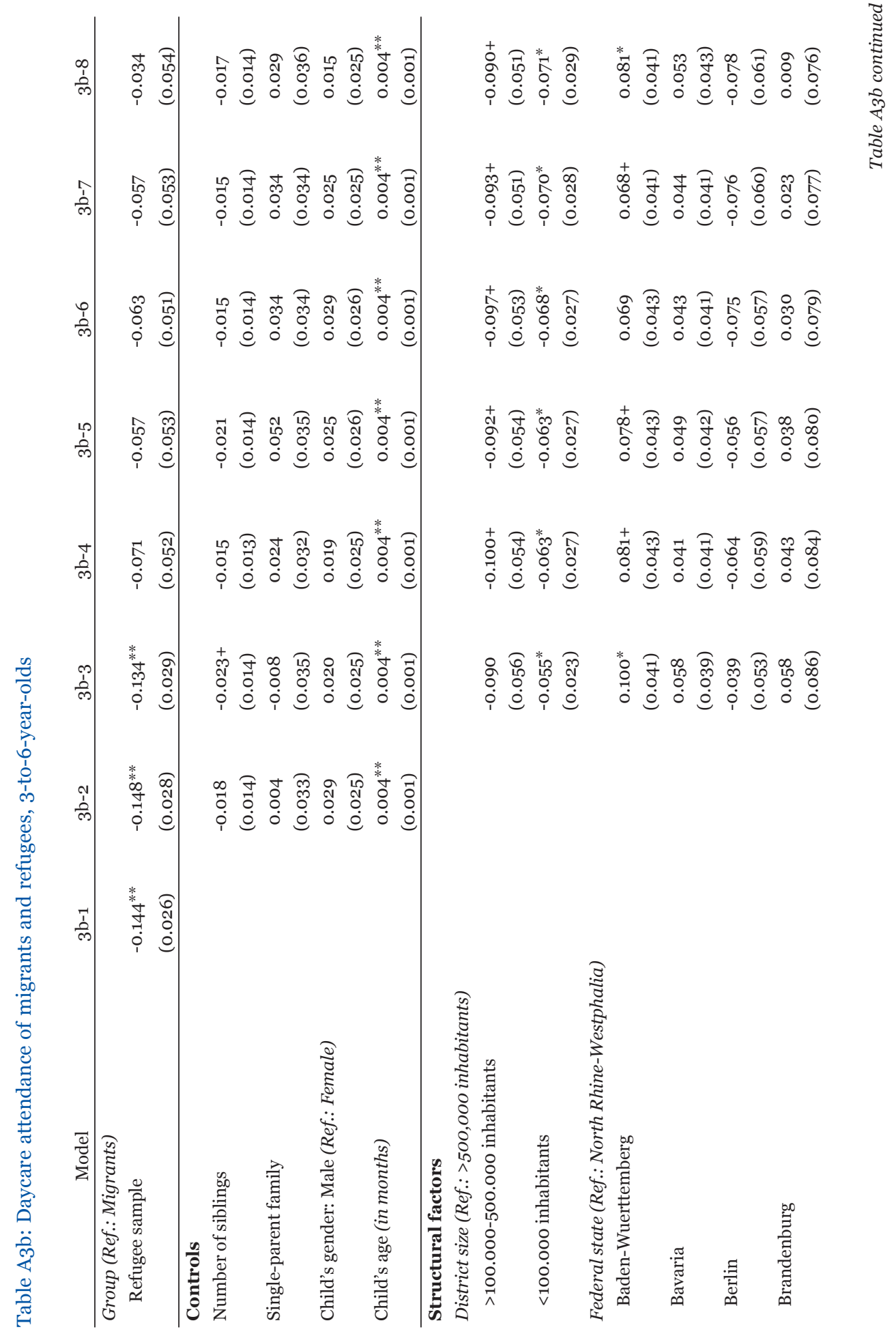




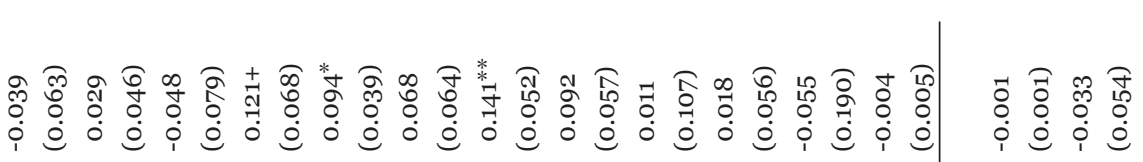

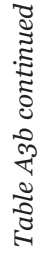

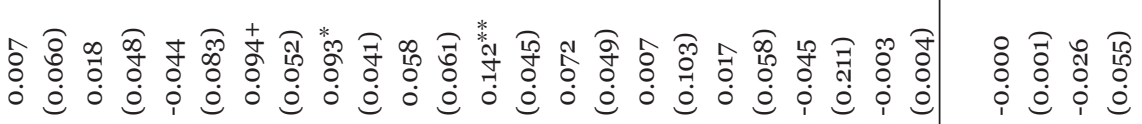

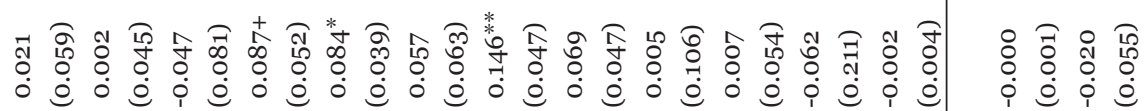

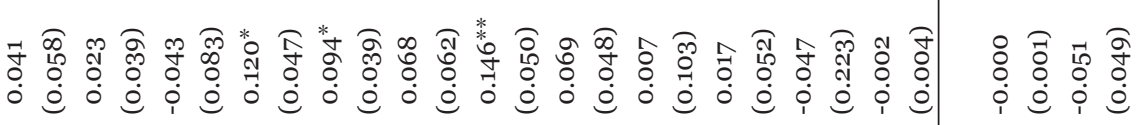

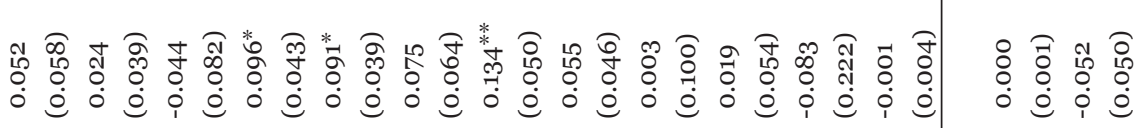

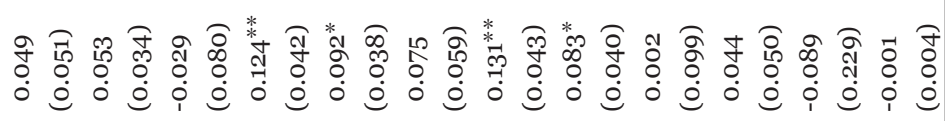

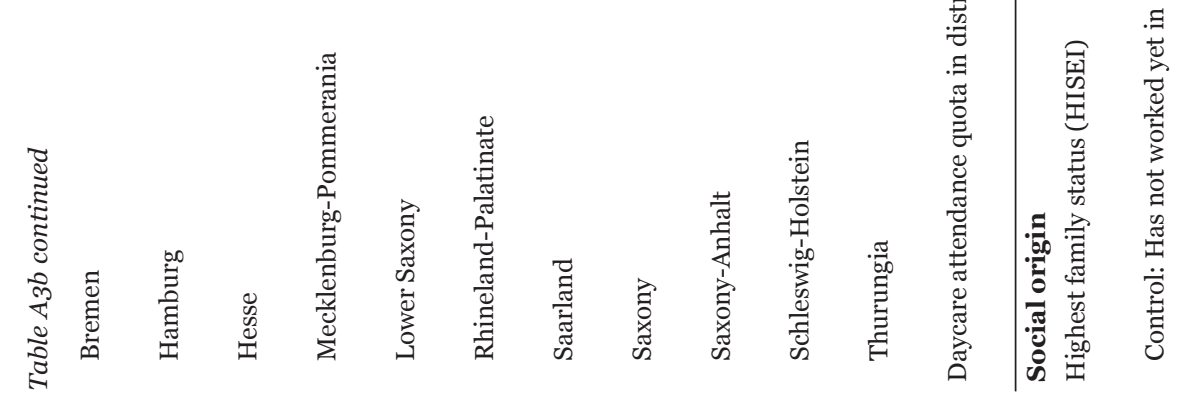


The role of socioeconomic, cultural, and structural factors in daycare attendance |

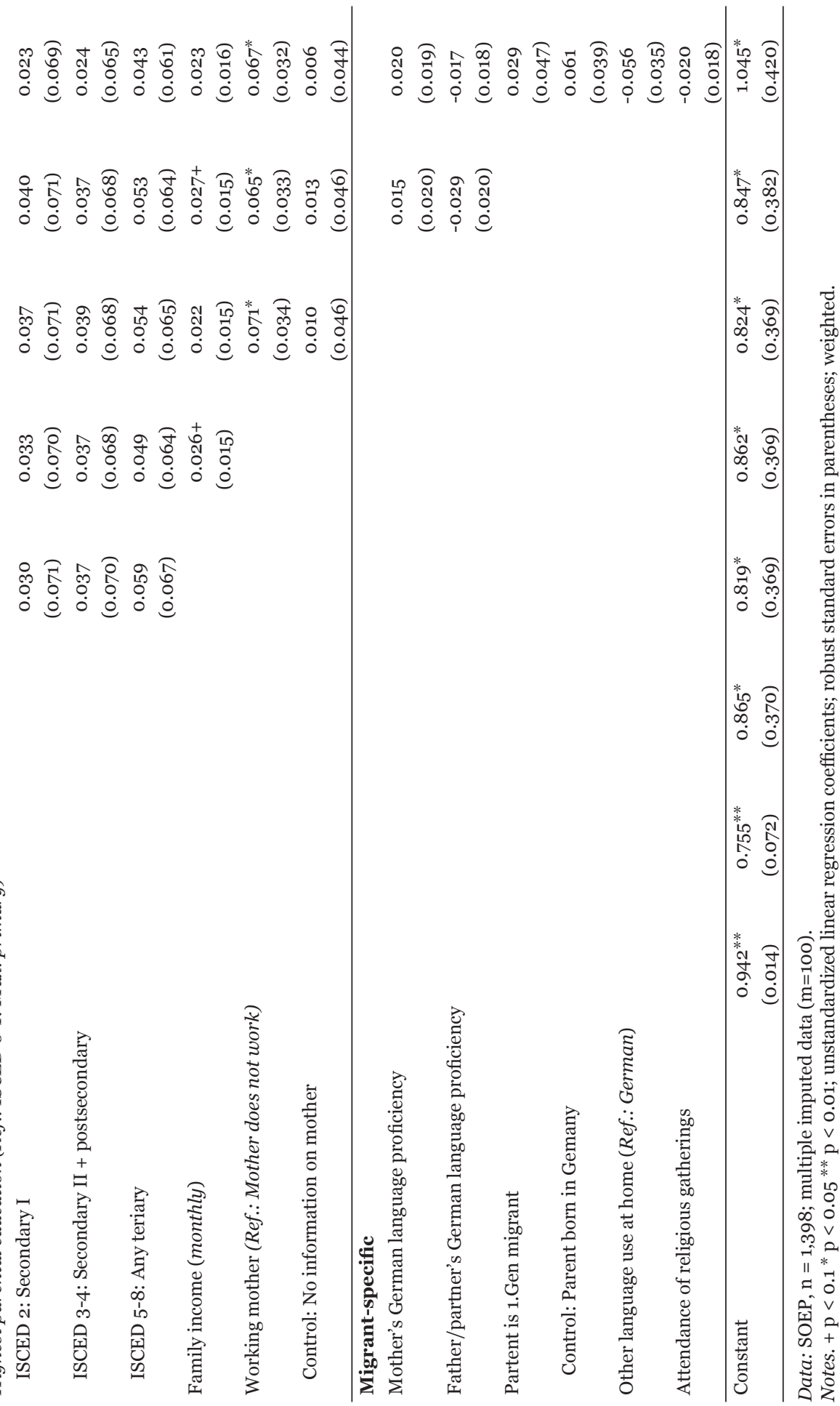




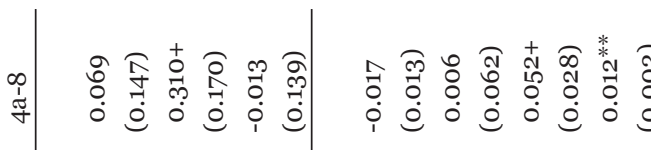

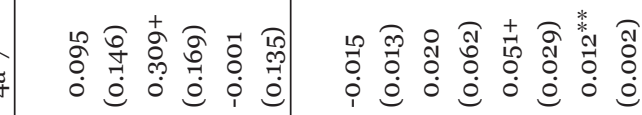

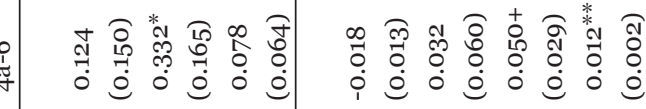

\begin{tabular}{llllll|lllllll} 
&
\end{tabular}

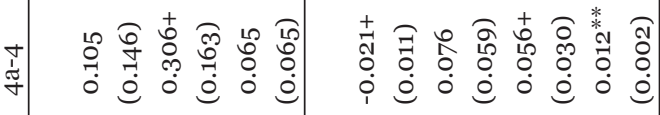

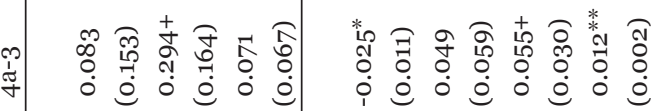

0
0
0
1
0
0
0
1
1
0
0
0

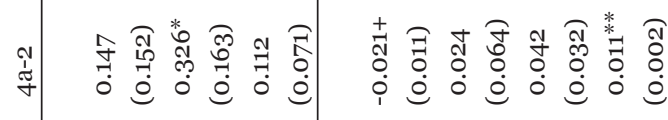

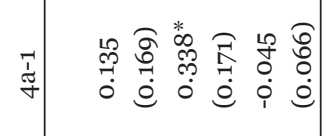

$\sum_{\substack{0 \\ \hline}}^{\infty}$

4

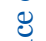

营

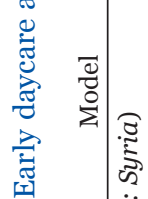

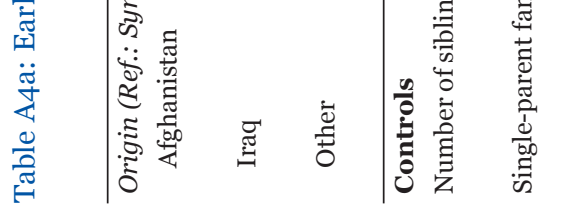

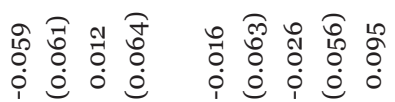

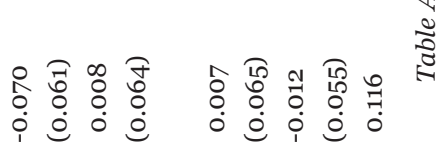

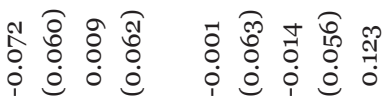

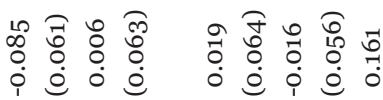

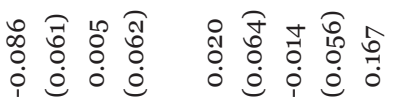

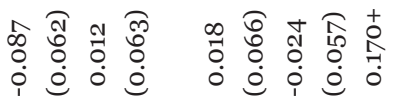


The role of socioeconomic, cultural, and structural factors in daycare attendance |

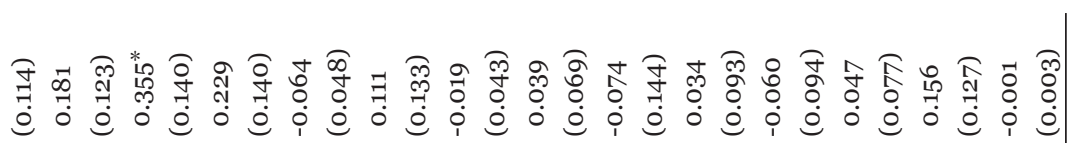

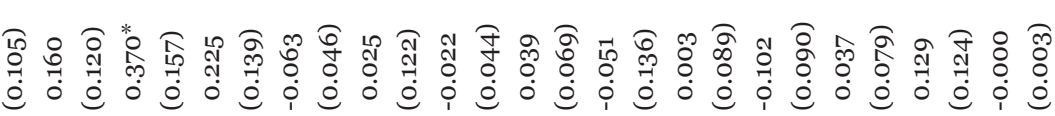

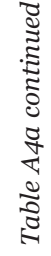

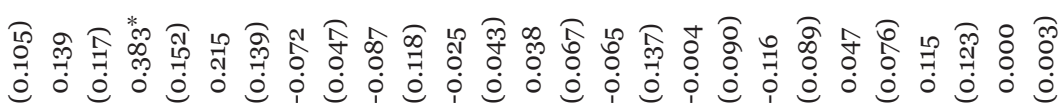

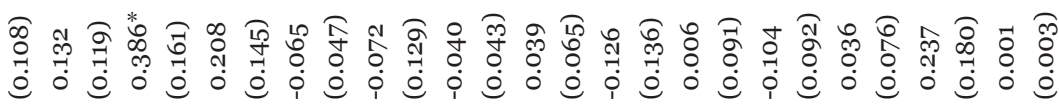

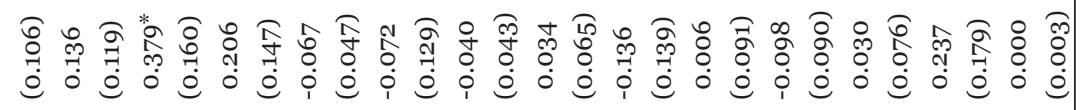

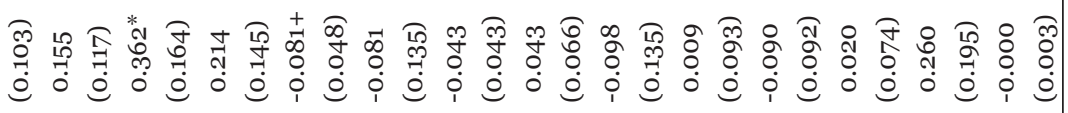

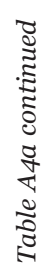

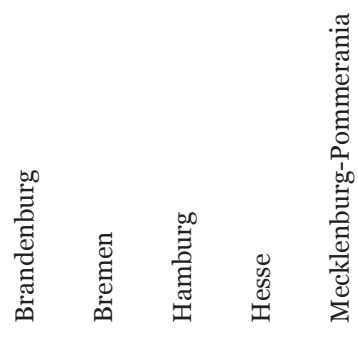

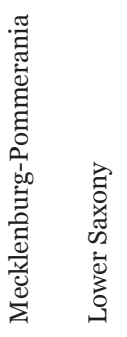

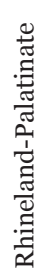

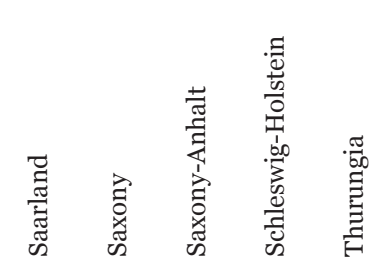

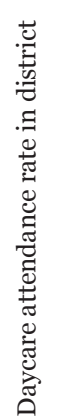

JERO, Vol. 13, No. 1 (2021) | 67 


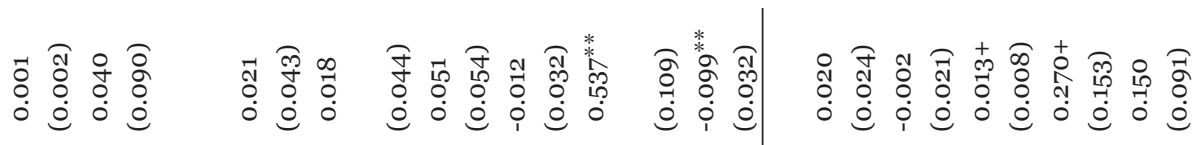

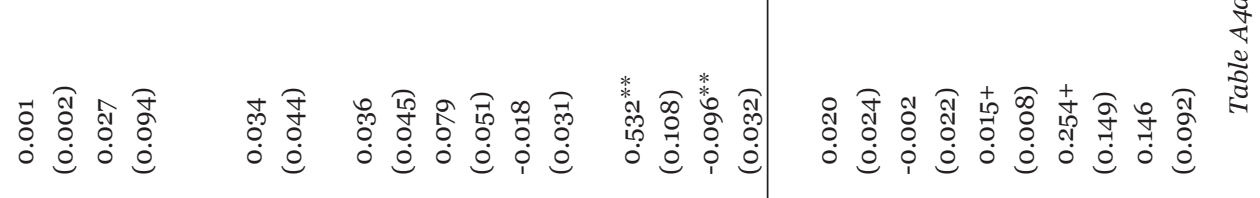

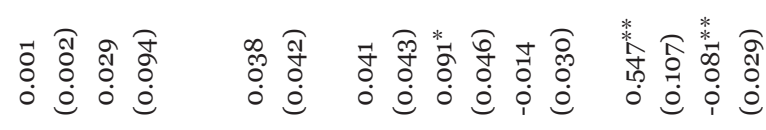

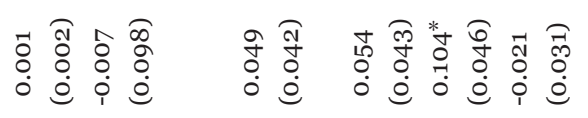

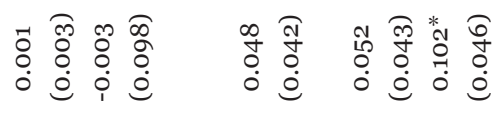

$$
\text { วิตู่ }
$$

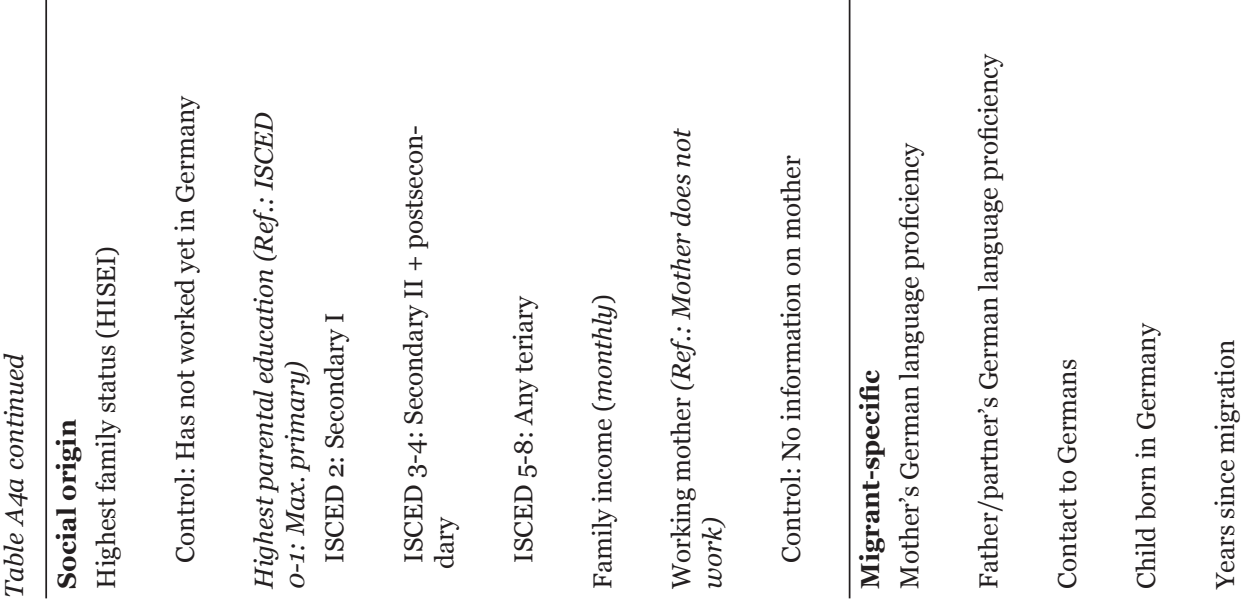


The role of socioeconomic, cultural, and structural factors in daycare attendance |

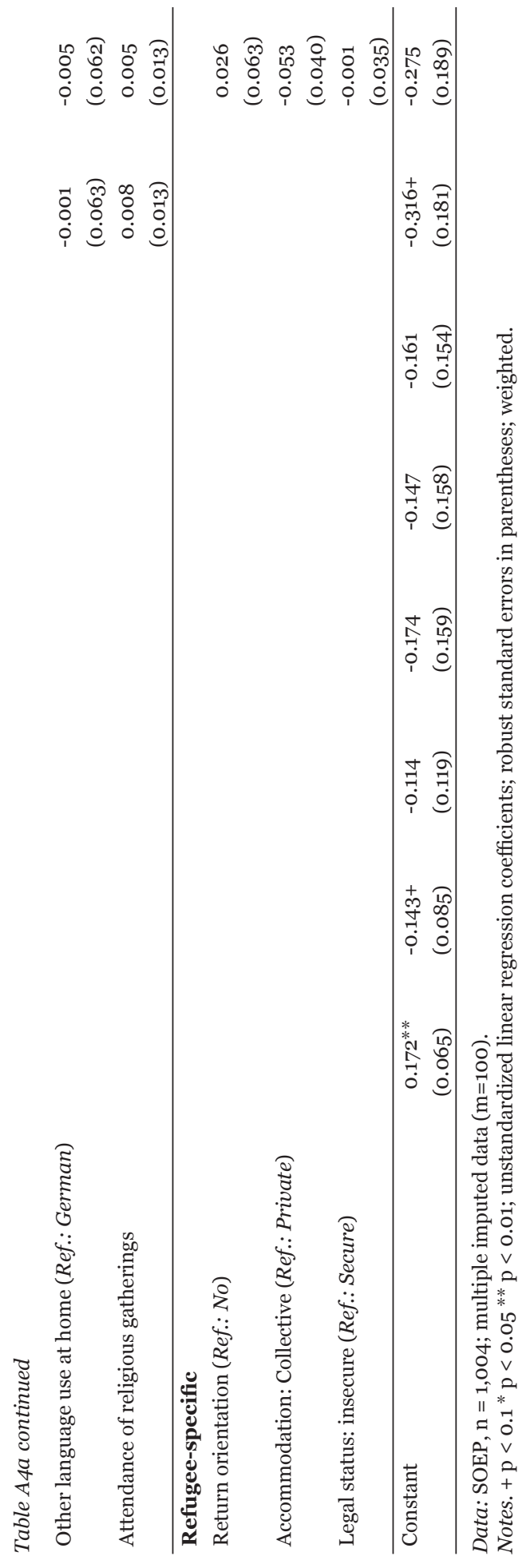

JERO, Vol. 13, No. 1 (2021) 
\begin{tabular}{l|llllll|llllll} 
& + & &
\end{tabular}

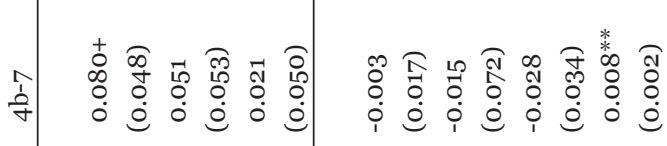

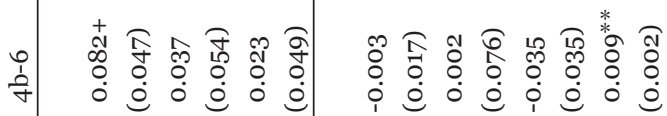

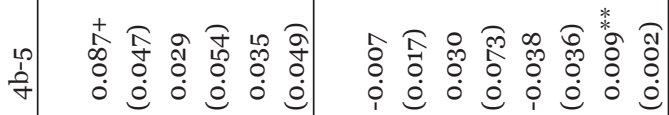

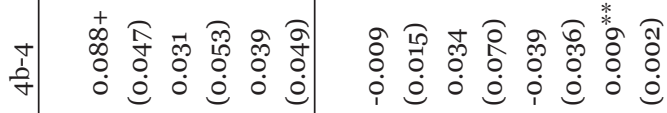

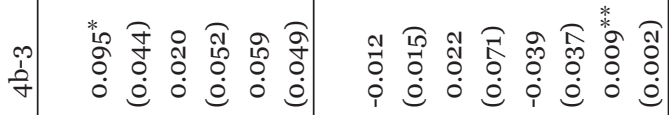

$\begin{array}{lllllllllllll} & * & & *\end{array}$

0
0
0
0
0
0
0
1
0
0
0
1
1

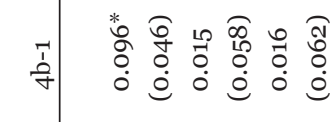

总

త

䒕

莺

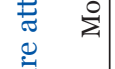

ప্ّ

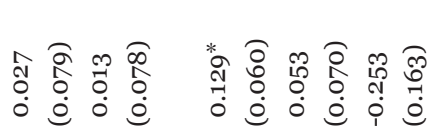

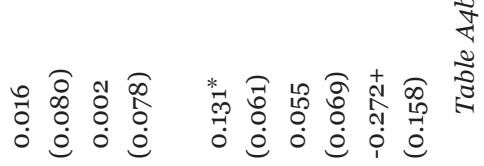

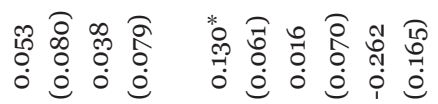

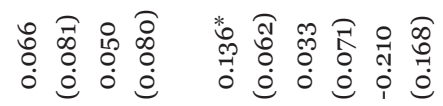

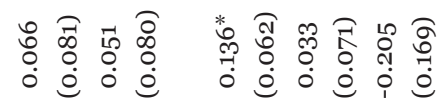

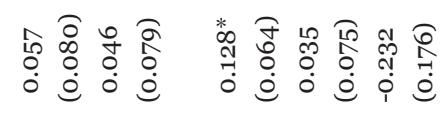

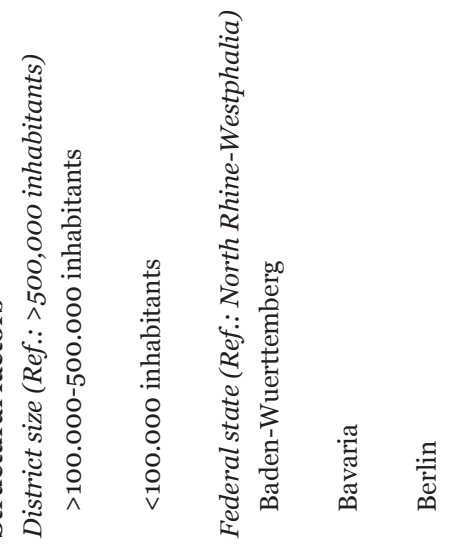


The role of socioeconomic, cultural, and structural factors in daycare attendance |

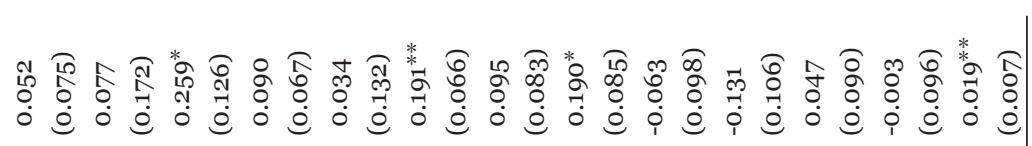

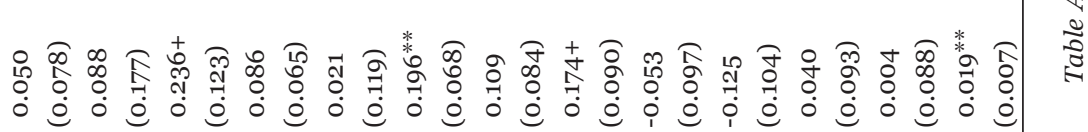

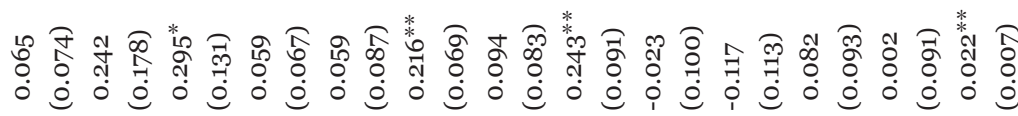

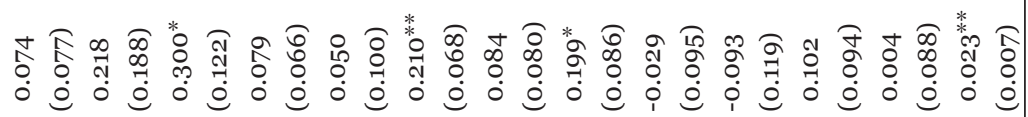

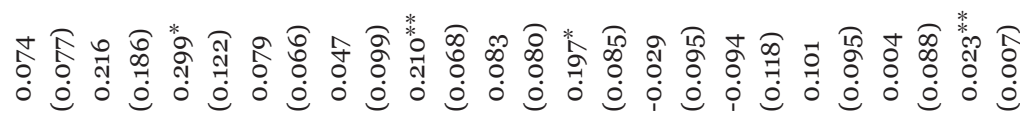

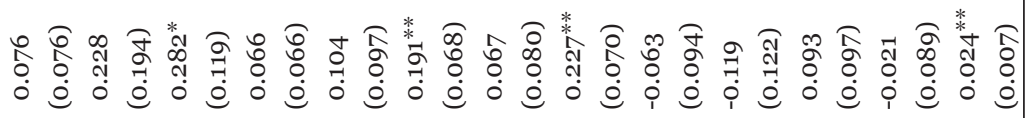

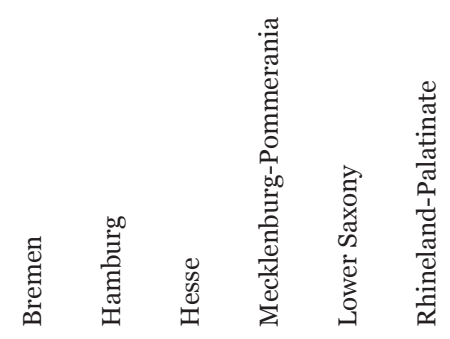

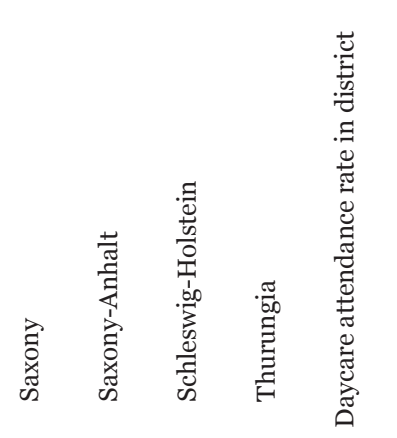




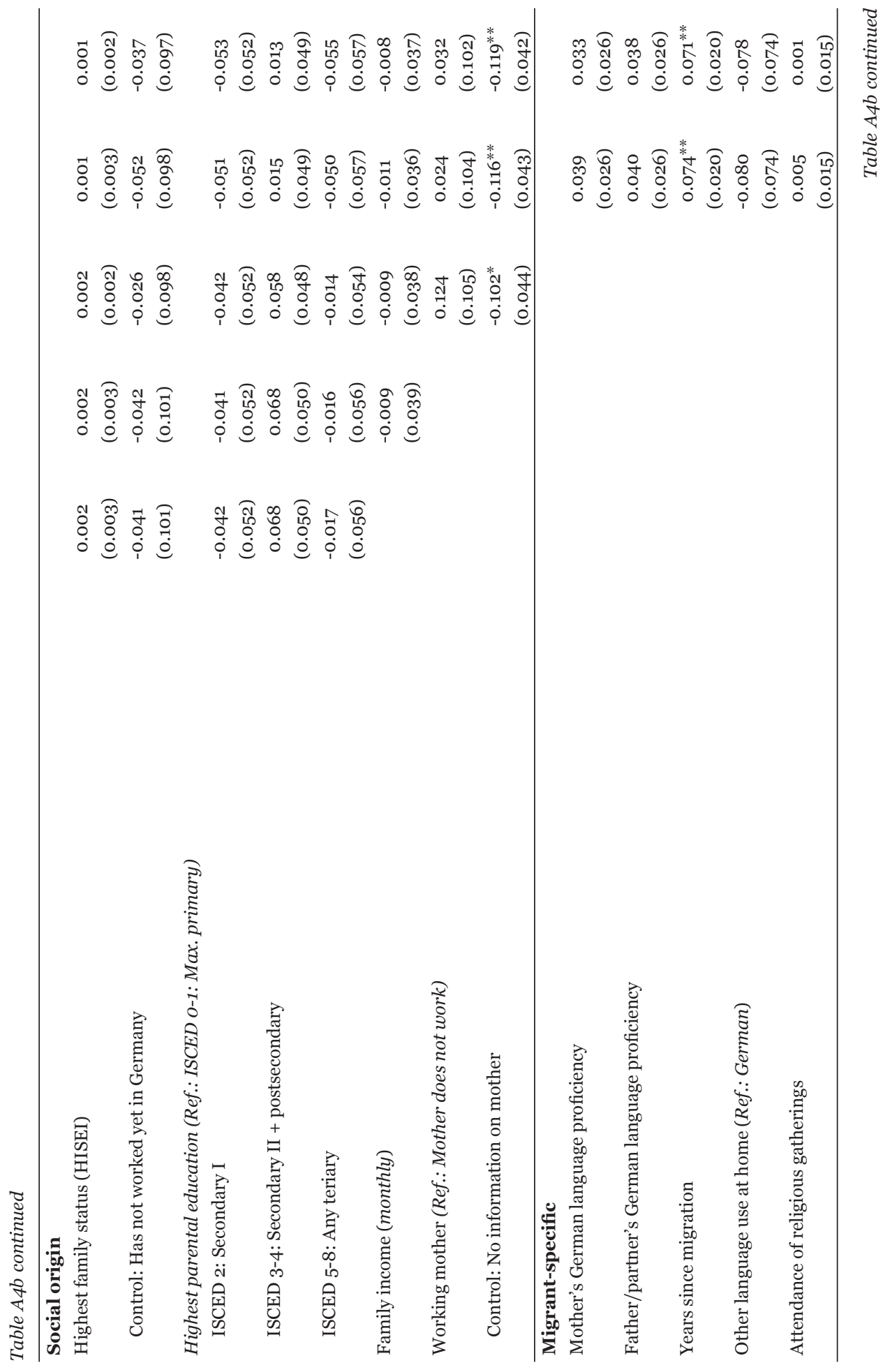

72 | JERO, Vol. 13, No. 1 (2021) 
The role of socioeconomic, cultural, and structural factors in daycare attendance |

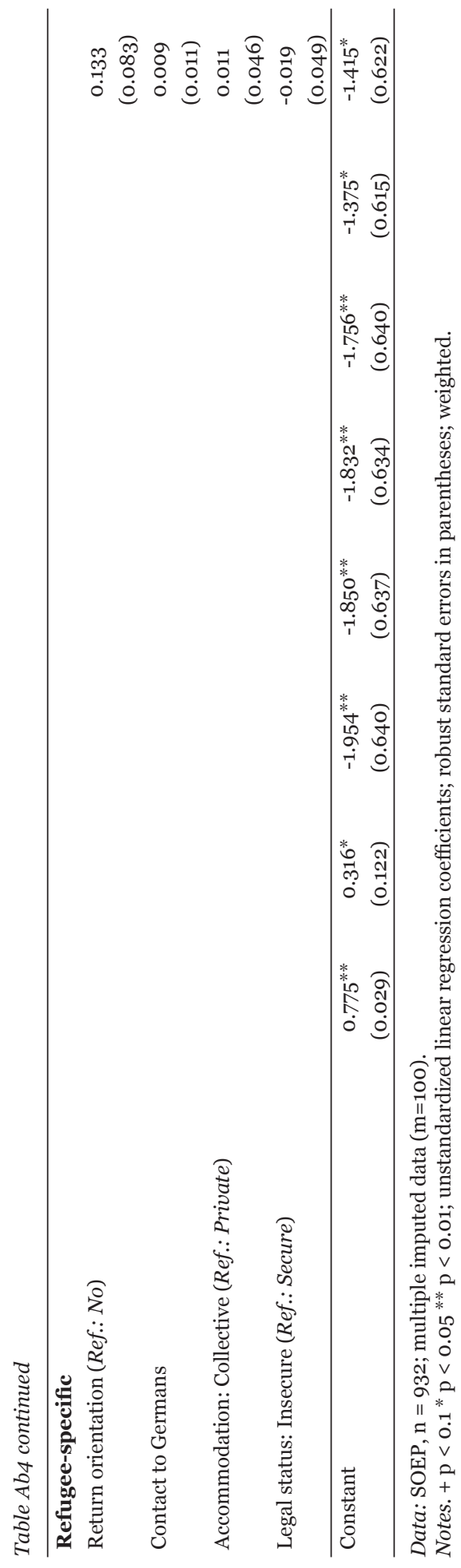

JERO, Vol. 13, No. 1 (2021) | 73 


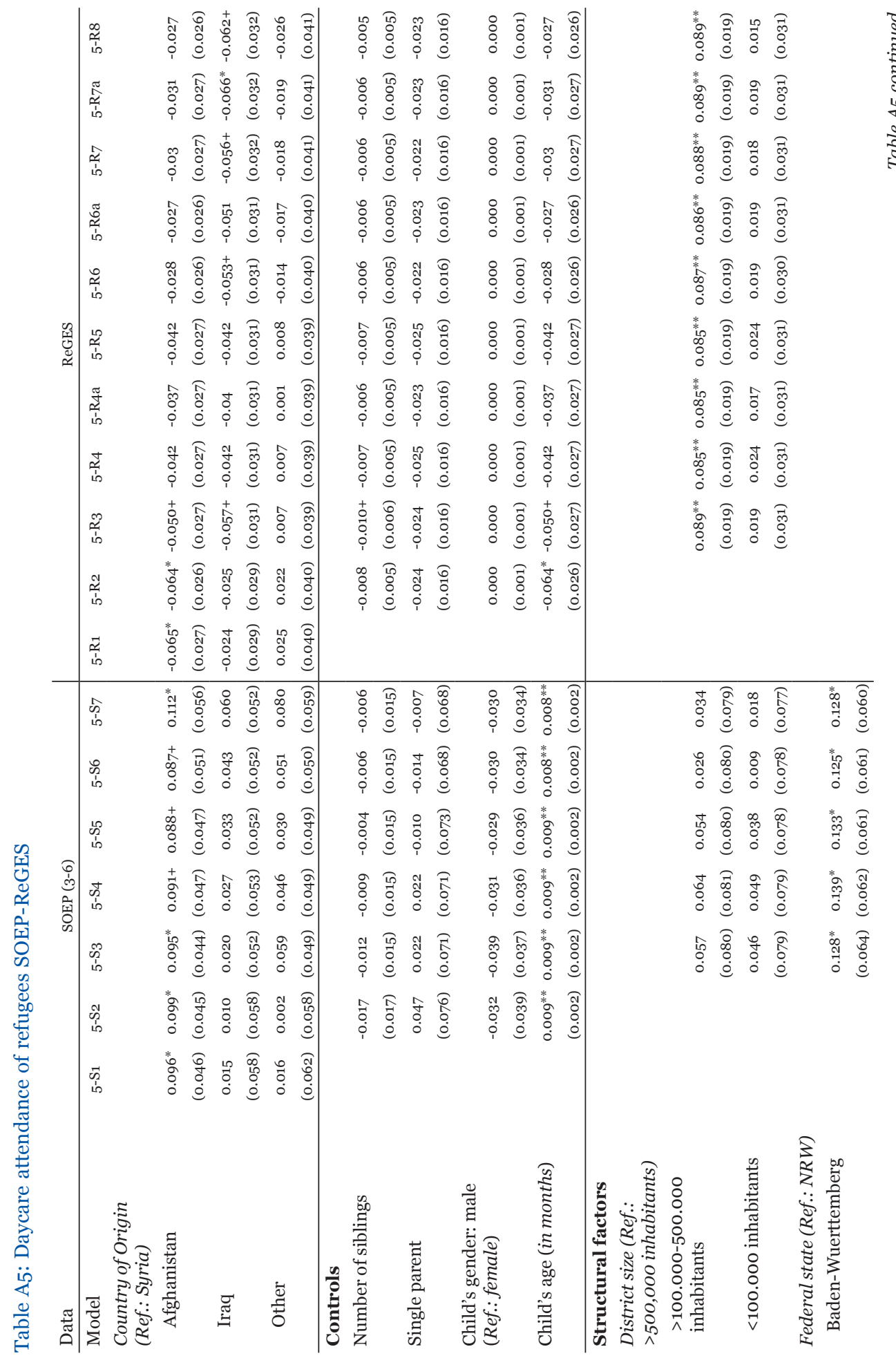


The role of socioeconomic, cultural, and structural factors in daycare attendance |

\begin{tabular}{|c|c|c|}
\hline 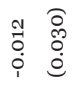 & 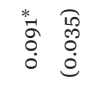 & $\begin{array}{ll}\infty & \widehat{c} \\
0 & 0 \\
0 & 0 \\
0 & \stackrel{0}{0}\end{array}$ \\
\hline $\begin{array}{l}\hat{0} \\
\hat{0} \\
\dot{0} \\
\dot{0} \\
\dot{0}\end{array}$ & $\begin{array}{ll}* & 0 \\
* 2 & 0 \\
0 & 0 \\
\dot{0} & 0\end{array}$ & \begin{tabular}{ll}
$\infty$ & \multirow{0}{0}{} \\
0 & 0 \\
0 & $\stackrel{0}{0}$
\end{tabular} \\
\hline 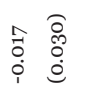 & $\begin{array}{ll}* & 0 \\
\text { o } & 0 \\
0 & 0 \\
\dot{0} & 0\end{array}$ & 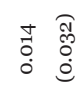 \\
\hline $\begin{array}{ll} & \hat{0} \\
\hat{0} & \stackrel{8}{\circ} \\
& 0 \\
& 0\end{array}$ & 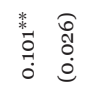 & $\begin{array}{ll}\infty & \text { of } \\
0 & 0 \\
0 & 0\end{array}$ \\
\hline 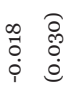 & $\begin{array}{ll}* & 0 \\
0 & 0 \\
0 & 0 \\
0 & 0\end{array}$ & 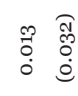 \\
\hline 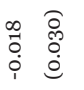 & $\begin{array}{ll}* & 0 \\
* & 0 \\
0 & 0 \\
0 & 0 \\
0 & 0\end{array}$ & $\begin{array}{ll}\infty & \widehat{c} \\
0 & 0 \\
0 & 0 \\
0 & \stackrel{\theta}{0}\end{array}$ \\
\hline 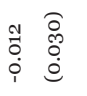 & \begin{tabular}{ll} 
* & 0 \\
\multirow{2}{*}{} & 0 \\
0 & 0 \\
0 & 0 \\
0 & 0
\end{tabular} & $\begin{array}{l}\hat{0} \\
\hat{0} \\
0 \\
0\end{array}$ \\
\hline 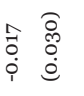 & \begin{tabular}{ll}
$*$ & 0 \\
\multirow{2}{*}{} & 0 \\
0 & 0 \\
0 & 0 \\
0 & 0 \\
0
\end{tabular} & $\begin{array}{ll}\infty & \widehat{0} \\
0 & 0 \\
0 & 0 \\
0 & \stackrel{0}{0}\end{array}$ \\
\hline 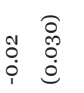 & \begin{tabular}{ll}
$*$ & 0 \\
\multirow{2}{*}{} & $\mathbb{1}$ \\
$\infty$ & 0 \\
0 & 0 \\
0 & 0
\end{tabular} & 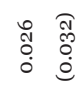 \\
\hline
\end{tabular}

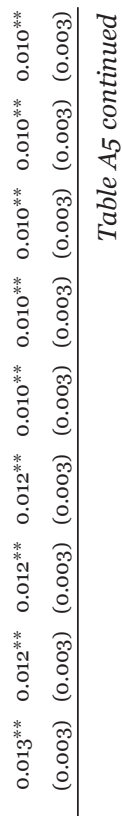

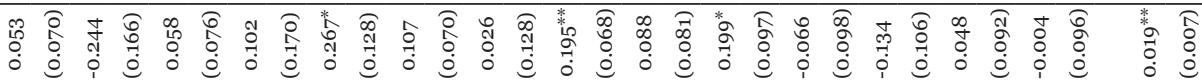

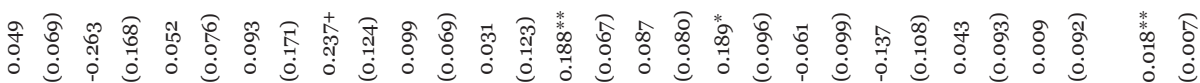

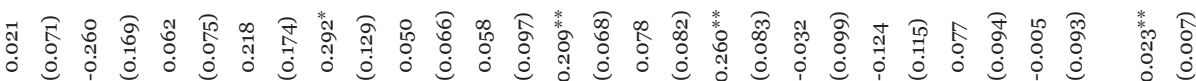

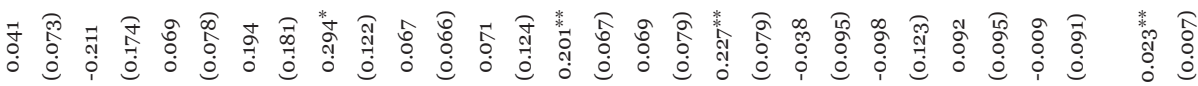

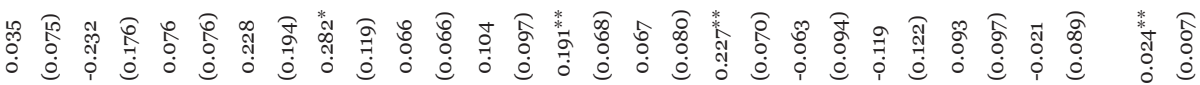

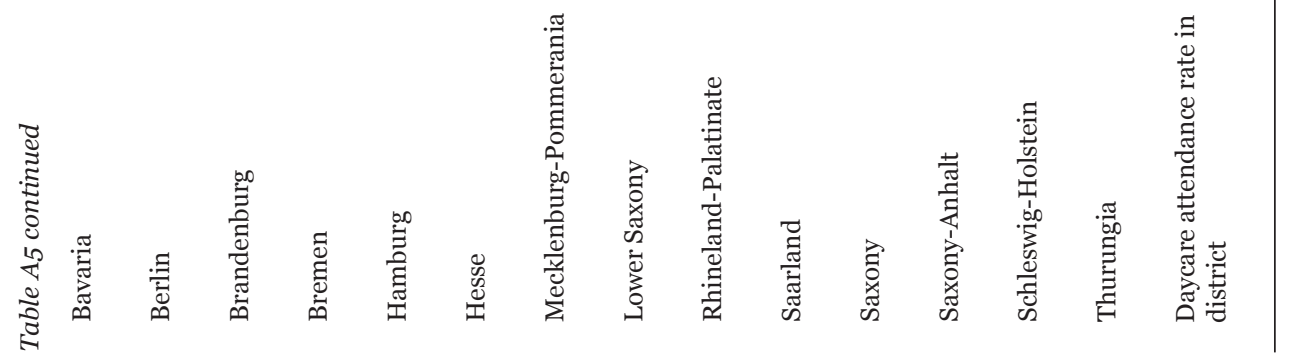


| Christoph Homuth, Elisabeth Liebau \& Gisela Will

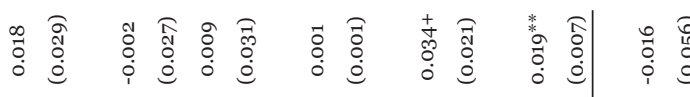

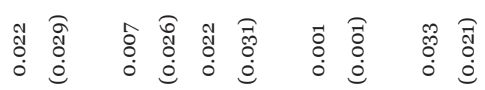

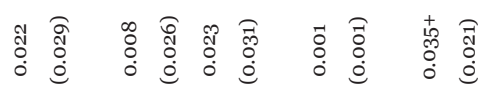

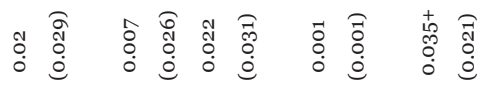

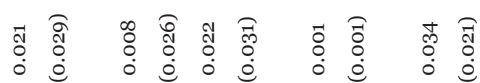

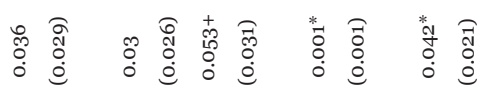

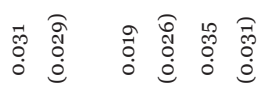

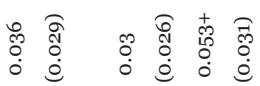

ริ)

옿

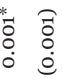

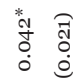

$\begin{array}{ll}7 & 0 \\ 0 & 0 \\ 0 & 0 \\ i & 0\end{array}$

$\begin{array}{ll}\infty & 0 \\ 0 & 1 \\ 0 & 0 \\ 0 & 0\end{array}$

$\begin{array}{ll}7 & 0 \\ 0 & 0 \\ 0 & 0 \\ 1 & 0\end{array}$

$\begin{array}{ll}\infty & 0 \\ 0 & 1 \\ 0 & 0 \\ 0 & 0 \\ 1 & 0\end{array}$

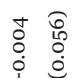

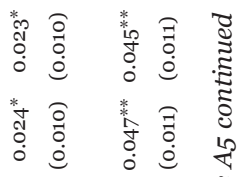

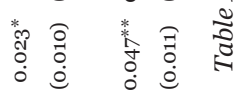

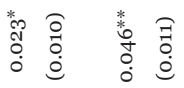

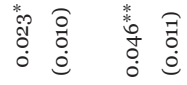

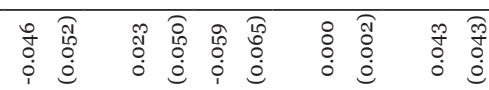

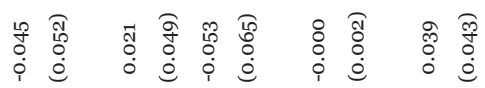

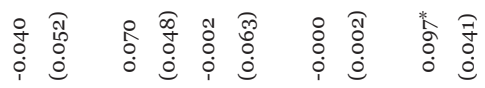

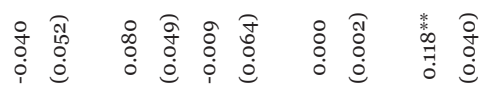

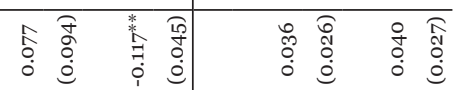

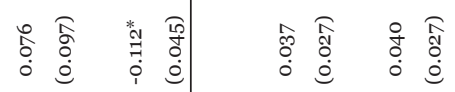

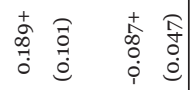

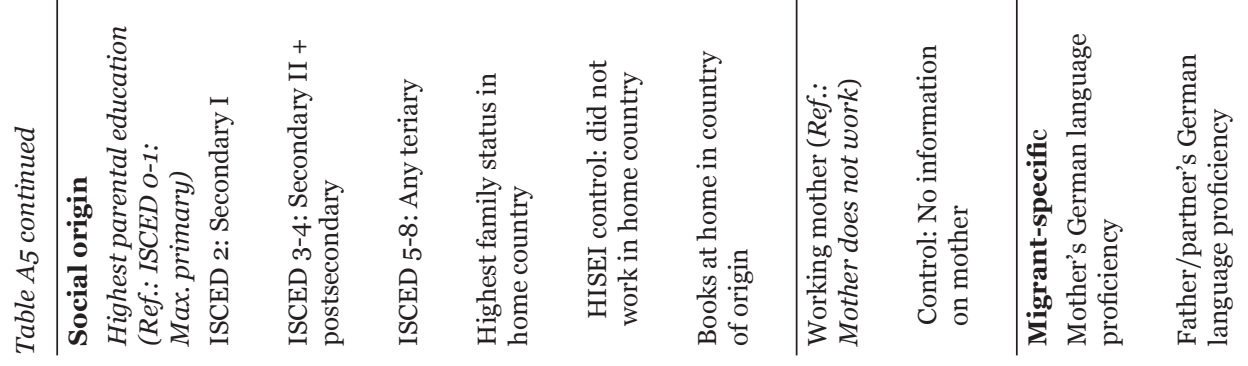


The role of socioeconomic, cultural, and structural factors in daycare attendance |

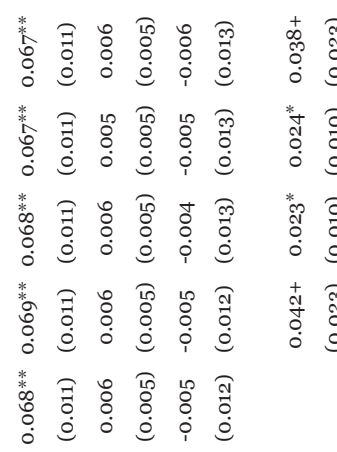

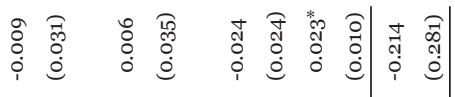

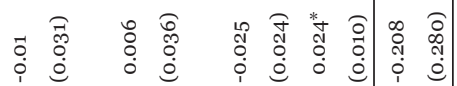

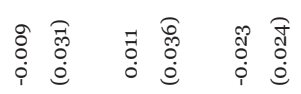

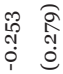

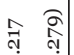

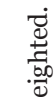

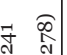

营

(1)

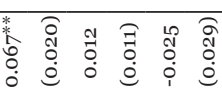

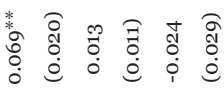

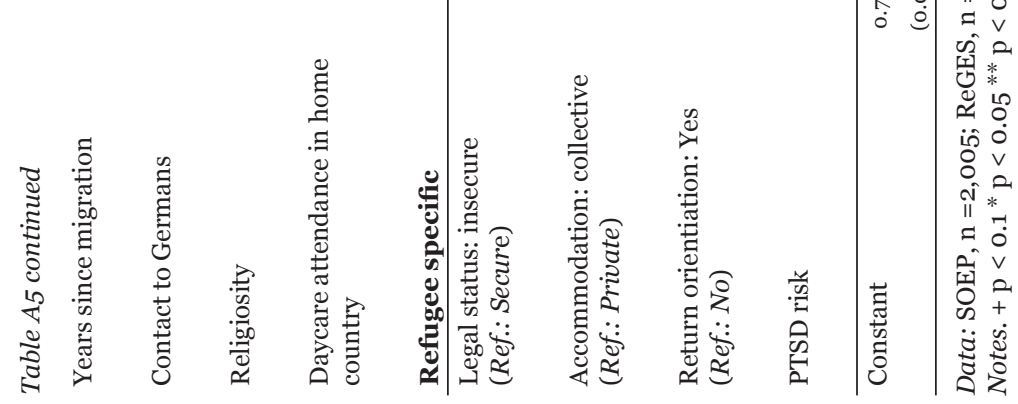

